\title{
Policy Levers Tailoring Patent Law to Biotechnology. Comparing US and European Approaches
}

\author{
Geertrui Van Overwalle
}

Professor of IP Law at the University of Leuven (Belgium)

Professor of Patent Law and New Technologies at the University of Tilburg (the Netherlands)

Working paper - April 2010

To be published in University of California Irvine Law Review (forthcoming)

\section{Table of content}

1. Introduction

1.1. "The patent crisis"

1.2. Objective and scope of the present study

1.2.1. European patent law

1.2.2. Policy levers

1.2.3. Biotechnology

2. Biotech-specific policy levers in Europe

2.1. Patent acquisition

2.1.1. Patentable subject matter - inventions and discoveries

2.1.2. Patentable subject matter - morality

2.1.3. Patentable subject matter - medical methods

2.1.4. Novelty - first and second medical use

2.1.5. Novelty - selection invention

2.1.6. Novelty - testing exemption

2.1.7. Inventive step - expectation of success

2.1.8. Inventive step - secondary indicia - commercial success

2.1.9. Industrial applicability

2.1.10. Skilled person

2.2. Patent scope

2.1.11. Enabling disclosure

2.2.1. Scope of product claims - absolute vs. limited scope

2.2.2. Clarity of claims

2.2.3. Breadth of claims

2.3. Patent rights and limitations

2.3.1. Research exemption

2.3.2. Compulsory licensing

3. Conclusions

$$
\text { 2.3.3. Patent term }
$$

3.1. European policy levers in biotechnology

3.1.1. Policy levers

3.1.2. Macro versus micro policy levers

3.1.3. Statutory versus jurisprudential policy levers

3.1.4. Pre-grant versus post-grant policy levers

3.1.5. European versus national policy levers

3.1.6. Private interest versus public interest levers

3.2. Comparing European and US policy levers

4. Critical assessment. "The patent crisis" revisited

4.1. Role and motivation for tailoring

4.2. Role of the courts

5. Final remarks

5.1. Future research

5.2. Concluding thoughts 


\begin{abstract}
In their animated book The Patent Crisis and How the Courts can Solve It, Dan Burk and Mark Lemley give an account of their quest into the judicial treatment of patents in different industry sectors. They present an in-depth commentary on industry specific differences in the patent system from both a legal and economic perspective. The present article attempts to enrich the conversation by sketching the situation in Europe and providing an interesting measure for comparison. In doing so, the paper mainly focuses on the legal situation, and does not enter into the economics discussion.

The paper concludes that current European patent law holds substantial potential for technology-specific application. Even though the European Convention (EPC) may have been conceived at its inception as a nominally neutral patent statute, our study clearly reveals that substantial discretion to differ the patent system by industry, and in particular to tailor it to the specificities of the biotechnology sector, is built into the system over the years. Although the EPC was introduced as a unitary regulatory tool, intended to operate the same way across technologies, EPO case law has shown increased interest and ability in tailoring patent law to the needs of distinct technology sectors, and in particular the biotechnology sector.

Given the civil law tradition in which European patent law operates, a prevalence of well articulated macro rules openly set forth by the legislature was anticipated. However, a clear predominance of jurisprudential micro policy levers has emerged.

Not all European policy levers uncovered in the present study, come to the advantage of the biotechnology industry. Closer analysis of the various policy levers, reveals that rather than systematically expanding the patent system to accommodate biotechnology inventions and stimulating innovation in the biotechnology sector, some policy levers narrow down the patent potential for biotechnological inventions, in an attempt to give echo to concerns of public health and ethical conscience.
\end{abstract}




\section{Introduction}

\section{1. "The patent crisis"}

In their book The Patent Crisis and How the Courts can Solve It, ${ }^{1}$ Burk and Lemley start from the observation that today's technology world is characterized by differing innovation and patent patterns per sector. Innovation is not all of a piece and innovation patterns and $R \& D$ expenditures may differ from industry to industry in a variety of ways. ${ }^{2}$ Those differences extend to the way in which industry players experience the patent system and results in patent patterns which may vary from industry to industry as well. Firms' propensity to obtain patents differs across sectors ${ }^{3}$ and some industries rely more heavily on patents than others. Patent prosecution processes diverge according to industry and getting a patent is quicker, cheaper and easier in some industries than in others. ${ }^{4}$ Distribution of value itself varies systematically by industry. ${ }^{5}$ Even the effective scope of granted patents is different by industry, and there is not always a one-to-one correspondence between a single patent and a single product. ${ }^{6}$ And, the construction of a patent portfolio is also industry specific. ${ }^{7}$

Focusing on the pharmaceutical industry, Burk and Lemley set forth that the pharmaceutical industry is characterized by non-cumulative innovation, where the need for further research on a particular drug after FDA approval is not high. ${ }^{8}$ As to patent protection, there seems to be a strong consensus that patent strategies are well established in the pharma industry, that this sector heavily relies on patent protection and that it is one of the key users of the patent system. ${ }^{9}$ In the biotechnology sector, patent protection is quite often also seen as critical to innovation ${ }^{10}$, even though concerns have arisen about the many upstream patents that might

\footnotetext{
${ }^{1}$ Burk, D.L. \& Lemley, M.A., The Patent Crisis and How the Courts Can Solve It, Chicago-London, The University of Chicago Press, 2009 (further abbreviated as Burk \& Lemley, The Patent Crisis, 2009).

2 See Burk \& Lemley, The Patent Crisis, 2009, 5, 38, 39-41. A few other significant quotes in the same sense: "The evidence is overwhelming that, at virtually every stage of both the innovation and patent processes, different industries have different needs and experience the patent system differently" (Burk \& Lemley, The Patent Crisis, 2009, 65); "It makes little sense to speak generally about innovation or about patents" (Burk \& Lemley, The Patent Crisis, 2009, 65); "We do not have a unitary patent system today, if by unitary you mean one system that works the same way everywhere. We have one set of legal rules, but the industries affected by the rules operate in very different patent systems" (Burk \& Lemley, The Patent Crisis, 2009, 65)

${ }^{3}$ Burk \& Lemley, The Patent Crisis, 2009, with reference to Brower, E., \& Kleinknecht, A., Innovatie Output and a Firm's Propensity to Patent: An Exploration of CIS Micro Data, 28 Res.Pol 615, 1999; Scherer, F.M., Herzstein, S.E. \& Dreyfoos, A.W. et al., Patents and the Corporation, 1959, Harvard Business School, Boston, MA, 195p.

${ }^{4}$ Burk \& Lemley, The Patent Crisis, 2009, with reference to Allison, J.R. \& Lemley, M.A., Who's Patenting What?An Empirical Exploration of Patent Prosecution, 53 Vanderbilt Law Review, (2099), 2124-32 (2000).

${ }^{5}$ Burk \& Lemley, The Patent Crisis, 2009 with reference to Schankerman, M., How valuable is Patent Protection? Estimates by Technology Field, 29 RAND J. Econ. 77, 79 (1998).

${ }^{6}$ Burk \& Lemley, The Patent Crisis, 2009, 53.

7 Burk \& Lemley, The Patent Crisis, 2009, with reference to Parchomovsky, G. \& Wagner, R.P., Patent Portfolios, 154 U.Pa.L.Rev. 1 (2005).

${ }^{8}$ Burk \& Lemley, The Patent Crisis, 2009, 33.

${ }^{9}$ Burk \& Lemley, The Patent Crisis, 2009, with reference to Lanjouw, J.O. \& Cockburn, I., Do Patents Matter? Empirical Evidence after GATT, National Bureau of Economic Research Working Paper No 7495, 2000. However, compared to other industries, pharma and biotech do not patent intensely, at least not in Europe. The EPO statistics of 2008 clearly show that the top of the leading 25 applicants were again Philips, Siemens (now up to second place) and Samsung. Not a single pharma or biotech company, apart from Bayer, was listed in the top 25 (See "Leading applicants and patentees in 2008", in EPO Annual Report 2008, p. 21).

${ }^{10}$ Burk \& Lemley, The Patent Crisis, 2009, 4
} 
hamper the development of final drugs and therapies. ${ }^{11}$ As to patent prosecution, chemical, pharmaceutical and biotechnological patents seem to spend much longer in prosecution, cite more prior art, and are abandoned and refiled more frequently. ${ }^{12}$ As to value distribution, the chemical and pharmaceutical industries hold patents with more consistent value. ${ }^{13}$ As to scope, the chemical and pharmaceutical sectors are characterized by a patent-to-product correspondence, where a single patent normally covers a single product, new chemical or a new use for that chemical. ${ }^{14}$ And in industries such as pharmaceuticals, characterized by patent-to-product correspondence, patent portfolios are rare: pharmaceutical companies may seek a few patents covering the same pharmaceutical product, thus patenting metabolites, extended release formulations, enantiomers, or processes of use. ${ }^{15}$ These patents are usually used to try to extend patent life: rather than creating a "thicket" of patents surrounding a complex of products ${ }^{16}$, they create a "cluster" of patents surrounding one product or technology to prolong the protection (and related income) of a blockbuster. ${ }^{17}$

Based on the overwhelming economic evidence that innovation and patent patterns are different in different industries, Burk and Lemley conclude that a purely unitary system no longer fits the diverse needs of technology innovation. Burk and Lemley put forward a twofold solution. The authors first claim that an adequate response to industry specific innovation and patent patterns requires tailoring the unitary patent rules to the needs of the different industries, rather than splitting the unitary patent system into industry-specific protection statutes. ${ }^{18}$ The great flexibility in the patent statute presents an opportunity to take account of the needs and characteristics of different industries. ${ }^{19}$ The authors further argue that an adequate solution further requires letting the courts carry out the tailoring, rather than the Congress or the Patent Office. ${ }^{20}{ }^{21}$ Courts have substantial ability to profile an industry inductively, by hearing cases presenting recurrent themes. ${ }^{22}$ Courts are equipped with precisely such discretion via a series of doctrinal policy levers. ${ }^{23}$ Policy levers permit to take account of the technology-specific nature of the patent system without inviting the rentseeking and balkanization that specialized statutes would engender. ${ }^{24}$

\footnotetext{
${ }^{11}$ See Heller, M.A., and Eisenberg, R.S., 'Can Patents Deter Innovation? The Anticommons in Biomedical Research', 280 Science, 1998, 698-701.

${ }^{12}$ Burk \& Lemley, The Patent Crisis, 2009, with reference to Allison, J.R. \& Lemley, M.A., Who's Patenting What? An Empirical Exploration of Patent Prosecution, 53 Vanderbilt Law Review, (2099), 2124-32 (2000).

${ }^{13}$ Burk \& Lemley, The Patent Crisis, 2009, with reference to Schankerman, M., How valuable is Patent Protection? Estimates by Technology Field, 29 RAND J. Econ. 77, 79 (1998).

${ }^{14}$ Burk \& Lemley, The Patent Crisis, 2009, 53.

${ }^{15}$ Burk \& Lemley, The Patent Crisis, 2009, 55.

${ }^{16}$ Burk \& Lemley, The Patent Crisis, 2009, 55.

${ }^{17} \mathrm{Cf}$. the findings of the EU Pharma sector inquiry, see the Final Report of the Pharmaceutical sector inquiry, 8 July 2009 (available at http://ec.europa.eu/competition/sectors/pharmaceuticals/inquiry/index.html).

${ }^{18}$ Burk \& Lemley, The Patent Crisis, 2009, 5.

${ }^{19}$ Burk \& Lemley, The Patent Crisis, 2009, 109.

${ }^{20}$ Burk \& Lemley, The Patent Crisis, 2009, 5.

${ }^{21}$ A few quotes which illustrate their point quite well: "One obvious response to the different policy prescriptions described would be to legislate different patent standards for each different industry. We resist that conclusion, however" (Burk \& Lemley, The Patent Crisis, 2009, 95); "Only a dynamically interpreted statute can hope to meet the needs of so many disruptive industries" (Burk \& Lemley, The Patent Crisis, 2009, 103); "We suggest that, as a general principle' a flexible common-law approach of ongoing judicial oversight will best accommodate new and different technologies within the general framework of a patent statute" (Burk \& Lemley, The Patent Crisis, 2009, 104).

${ }^{22}$ Burk \& Lemley, The Patent Crisis, 2009, 105-06.

${ }^{23}$ Burk \& Lemley, The Patent Crisis, 2009, 104.

${ }^{24}$ Burk \& Lemley, The Patent Crisis, 2009, 95.
} 


\subsection{Objective and scope of the present study}

The major objective of the present study is to discern policy levers in European patent law in biotechnology. We aim to portray specific policy levers as introduced by European legislature in the sector of biotechnology and paint the way in which particular policy levers have been deployed in European case law to enhance innovation in biotechnology. By sketching the situation in Europe, we attempt to enrich the conversation by providing an interesting measure for comparison with US policy levers.

Before we start our European quest, let us first take a closer look at the concepts which are quintessential to our study.

\subsubsection{European patent law}

The present study will watch out for policy levers in European patent law, in other words in European legislation and case law. Given the civil law tradition in Europe, it is quite likely that relevant policy levers will not only be uncovered that have been created by courts but (even more so) by legislators sensitive to the needs and characteristics of different industries. Apart from courts applying the patent system differently, the legislatures may well have created specific rules within specific industries as well.

\section{Legislation}

In Europe, patent legislation relevant to biotechnology comes about at three distinct levels: the national level, the European-EPO level and the European-EU level. This needs some further explanation. For the time being, it is possible to obtain patent protection in Europe by separate application to each of the national Patent Offices within Europe (The so-called National Route). Almost every country within Europe has its own patent system as well as a Patent Office or equivalent bureaucracy to screen patent applications and to decide whether patents should be awarded. However, the disadvantage of a national patent is that it only offers protection in one country, and hence it is mostly a European patent that is opted for at the European Patent Office (EPO) (The so-called European Route). On the basis of a single application and examination procedure it is possible to protect an invention in up to 36 European countries, all contracting states which have ratified the European Patent Convention (EPC). ${ }^{25}$ After the uniform application and granting procedure has led to the deliverance of a patent by the EPO, the patent is then broken up into a bundle of national patents which are further subject to national legislation and, more particularly, to national rules with regard to nullification and impairment (see articles 2(2) and 64 (1) EPC). ${ }^{26}$ It is repeated that the European patent is granted by the EPO, an independent international organization which is not part of the institutional framework of the European Union (EU). European patents have nothing to do with the EU apart from the fact that all EU member states have also signed the EPC.

\footnotetext{
${ }^{25}$ European Patent Convention of 5 October 1973, as revised by the EPC Revision Act of 29 November 2000 and entered into force in 2007, its Implementing Regulations and protocols and the Rules relating to Fees.

26 "The European patent shall, in each of the Contracting States for which it is granted, have the effect of and be subject to the same conditions as a national patent granted by that State, unless otherwise provided in this Convention" (Article 2 (2) EPC). "A European patent shall, subject to the provisions of paragraph 2, confer on its proprietor from the date of publication of the mention of its grant, in each Contracting State in respect of which it is granted, the same rights as would be conferred by a national patent granted in that State" (Article 64 (1) EPC).
} 
However, in a direct bid to resolve some lacunas and clarify some confusing obscurities with regard to bio-patenting in the EPC, and to harmonize EU member states' emerging legislations in this field, the EU mingled in the debate. The EU interference led to the adoption of a Directive on the legal protection of biotechnological inventions in $1998 .{ }^{27}$ At the same time, the Directive also represented a subtle attempt, the EU having no authority over the EPO, to steer the granting policy of the EPO in the field of biotechnology indirectly. The Directive was indeed incorporated into the EPC in $1999,{ }^{28}$ thus providing for the EPO more detailed guidelines with regard to the patenting of biotechnological inventions.

The present study will solely focus on European patents, and not deal with national patents. In view of the previous, statutes at all three legislative levels will thus (have to) be examined. First, the European EPO-level, including the EPC and its Implementing Regulations (IRs) ${ }^{29}$ which are an integral part of the EPC. ${ }^{30}$ The EPO Examination Guidelines ${ }^{31}$ will not systematically be discussed. Second, the European EU-level, encompassing the EU Biotechnology Directive. Third, the national level, focusing on a selection of national patent acts, more in particular the patent acts of Belgium, the Netherlands and France.

\section{Case law}

In Europe, case law on patents may emerge at the same three levels: the national level, the European-EPO level and the European-EU level. Indeed, case law will develop within three distinct institutional constellations: the national courts, the EPO and - exceptionally - the European Court of Justice (ECJ). The national courts apply and discuss the scope of national patent acts in the framework of purely national or European patents. The Technical Boards of Appeal and the Enlarged Board of Appeal apply and interpret the EPC. The European Court of Justice may provide rulings on patent law, in response to questions triggered by national courts. $^{32}$

\footnotetext{
${ }^{27}$ Directive 98/44/EC of 6 July 1998 of the European Parliament and of the Council on the legal protection of biotechnological inventions (Official Journal L 213, 30/07/1998 p. 0013).

${ }^{28}$ Notably as Chapter V (Rules 23 (b) to 23 (e) EPC IRs; now Rules 26 to 29 EPC IRs) of the Implementing Regulations to the EPC, which was inserted by decision of the Administrative Council of 16 June 1999, and which came into force on 1 September 1999.

${ }^{29}$ A package of new measures amending the EPC Implementing Regulations entered into force on 1 April 2010. These measures affect search, examination and time limits for the filing of divisional applications. The amendments aim to improve the quality of incoming patent applications and expedite the grant process. The changes will allow examiners to better coordinate with applicants and therefore enhance the legal certainty for the third parties and public, consequently improving the quality of patent information, among other things. The present study could not take into account this newest version of the Implementing Regulations, as this version was not available when preparing and writing the present paper (for more information, see http://www.epo.org/topics/news/2010/20102903.html).

${ }^{30}$ See EPO Technical Board of Appeal (T 931/95), 8 September 2000, OJ EPO, 2001, 441 (Pension Benefit Systems Partnership).

${ }^{31}$ Guidelines for Examination in the European Patent Office (2010), further abbreviated as EPO Guidelines (2010). By decision of the President of the EPO dated 19 November 2009, and after consultation with the Standing Advisory Committee before the EPO (SACEPO), the Guidelines for Examination have also been amended. The amended Guidelines will apply as from 1 April 2010. As the amended Guidelines were published on the EPO website in November 2009, the newest version has been taken into account in the present paper, whenever cited.

${ }^{32}$ For the time being, the ECJ cannot respond to questions arising within the EPO Cf. footnote hereafter.
} 
For the present study, mainly the case law of the EPO will be examined. Further research needs to be done to complement this analysis with a study of biotechnology related case law of the courts in EPC contracting states, and the - rather limited - case law of the ECJ. ${ }^{33}$

\subsubsection{Policy levers}

The present study will adopt the Samuelson and Scotchmer concept of policy levers, apply the Burk and Lemley macro/micro classification, but will deviate somewhat from the Burk and Lemley policy lever categories.

According to Samuelson and Scotchmer all intellectual property rights regimes - patent, copyright, trademark - have certain policy levers in common, wielded to a greater or lesser extent. Policy levers include, for example, length of protection, breadth of protection and some fair use or policy-based limitations on the scope of protection. By handling the available policy levers appropriately, legal regimes can be made sensitive to the technological and industrial contexts they regulate. ${ }^{34}$

Burk and Lemley build on the Samuelson and Scotchmer concept and identify a number of additional policy levers that already exist in patent jurisprudence to tailor the unitary patent system to the more complex realities of the world, such as eligible subject matter (abstract ideas), patentability requirements (non-obviousness and secondary indicia, utility), skilled person, enabling disclosure, pioneering patents and experimental use. ${ }^{35}$ The levers are not, by any means, the only sources of judicial discretion in patent law. Burk and Lemley have concentrated on policy levers that seem to require, or at least permit, systematic variation in patent rules by industry.

Burk and Lemley distinguish between macro and micro policy levers. Some policy levers operate on a macro level: they expressly treat different industries differently. Macro level policy levers may require courts to differentiate between industries (and treating, for example, biotechnological inventions differently than software inventions) or to focus on particular technologies (and treating, for example, DNA differently for certain purposes, than other technologies). ${ }^{36}$ A more common set of policy levers operates on the micro level: they treat different inventions differently without express regard to industry. ${ }^{37}$ Micro policy levers apply to inventions in all industries, but have particular significance for certain industries. ${ }^{38}$ In other words, at the micro level, many of the characteristics that are not expressly industryspecific, are nonetheless factors that vary systematically by industry. ${ }^{39}$

Burk and Lemley describe a dozen policy levers courts already use to differentiate patent law in different industries. They split them up into three major categories: (1) patent acquisition

\footnotetext{
${ }^{33}$ Two cases are currently pending before the ECJ. First, a request from the Dutch court of 's Gravenhage of 24 September 2008 concerning the scope of patent claims for transgenic plants (Articles 8 and 9 of the EU Biotechnology Directive) (See Bijblad Industriële Eigendom, 2009, 403). Second, a request from the German Bundesgerichtshof (the Federal Court of Justice) of 17 December 2009 concerning the ability of an inventor to patent methods and products involving the use of human embryonic stem cells (Article 6 of the EU Biotechnology Directive) (See Decision Xa ZR 58/07, available at www.bundesgerichtshof.de).

${ }^{34}$ Pam Samuelson \& Suzanne Scotchmer, The Law and Economics of Reverse Engineering, 111 Yale L.J., 1575, 1581 (2002).

${ }^{35}$ See Burk \& Lemley, The Patent Crisis, 2009, $109 \mathrm{ff}$.

${ }^{36}$ Burk \& Lemley, The Patent Crisis, 2009, 109. Also see Burk \& Lemley, The Patent Crisis, 2009, 129: "At the macro level, the courts look expressly at the conditions of the relevant industry to determine ... certain issues".

${ }^{37}$ Burk \& Lemley, The Patent Crisis, 2009, 110.

${ }^{38}$ Burk \& Lemley, The Patent Crisis, 2009, 123.

${ }^{39}$ Burk \& Lemley, The Patent Crisis, 2009, 129.
} 
and validity, (2) patent scope and (3) remedies for patent infringement. We will break up the policy levers in the following three categories: (1) patent acquisition, (2) patent scope, and (3) patent rights and limitations. This differing classification is rooted in the current institutionallegal architecture in which the EPO and European patents operate. More in particular, our classification is based on the allocation of competences in European patent law, and the foundational distinction between existence/exercise of patent rights (See Table 1. Relation between categories of policy levers and allocation of competences for European patents).

\begin{tabular}{|l|l|l|}
\hline Policy levers & & Level of regulatory competence \\
\hline $\begin{array}{l}\text { Relating to the coming into } \\
\text { existence of patents } \\
\text { (Pre-grant levers) }\end{array}$ & - Patent acquisition & EPO \\
\hline $\begin{array}{l}\text { Relating to the exercise of } \\
\text { patents } \\
\text { (Post-grant levers) }\end{array}$ & $\begin{array}{l}\text { Patent rights \& } \\
\text { patent limitations }\end{array}$ & EPC contracting states (+ EU) \\
\hline
\end{tabular}

Table 1. Relation between categories of policy levers and allocation of competences for European patents

The first two categories of policy levers - patent acquisition and patent scope - both relate to the coming into existence of patent rights: what policy levers can legislators and courts employ to modulate the coming into existence of patent rights in different sectors? The third category of policy levers - patent rights and limitations - relates to the exercise of patent rights: what policy levers can be observed to shape and limit patent rights? The first two categories are pre-grant policy levers, whereas the last category is a post-grant policy lever. According to prevailing case law, policy levers relating to rules or standards that affect the coming into existence and the scope of the patent - i.e. the determination of which subject matter is protected, and the extent of protection conferred by a patent - are the exclusive competence of the EPO. ${ }^{40}$ Policy levers relating to standards that deal with the exercise of rights of the patentee - i.e. the rights conferred by a patent upon patentee, and the determination of how subject matter is protected - are the competence of the EPO contracting states, and may come under the scrutiny of the EU. ${ }^{41}$

We expect that this division of competences will be reflected in the type of actors (legislators vs. courts; EPC Boards vs. national courts) putting into operation policy levers in Europe.

\subsubsection{Biotechnology}

In the framework of the present study four general categories of biotechnological inventions have been envisaged. First and foremost, human DNA sequences, in the context of recombinant production of human therapeutic proteins, as well as in the context of genetic testing. Second, human stem cells. Third, transgenic plants and transgenic plant cells (Lesser attention is paid to biological processes for the production of plants). Last but not least, transgenic animals and animal cells.

\footnotetext{
${ }^{40}$ EPO Enlarged Board of Appeal (G 02/88), 11 December 1989 (Mobil Oil III), OJ EPO, 1009, 93 (Point 3.3. of the Reasons.

${ }^{41}$ Court of Justice JEC, June 19718 (78/80) Deutsche Grammophon: "Amongst the prohibitions or restrictions on the free movement of goods which it concedes article 36 refers to industrial and commercial property. On the assumption that those provisions may be relevant to a right related to copyright, it is nevertheless clear from that article that, although the treaty does not affect the existence of rights recognized by the legislation of a member state with regard to industrial and commercial property, the exercise of such rights may nevertheless fall within the prohibitions laid down by the treaty" (Point_11 of the Reasons).
} 
The policy levers employed in the area of chemistry and pharmacy, bearing relevance for biotechnology, will also be discussed.

\section{Biotech-specific policy levers in Europe}

\subsection{Patent acquisition}

Now the objective and scope of the present study have been set forth, let us start our European quest for policy levers. We kick off by screening the elements pertaining to the acquisition of patents. In Europe, patents are available for any inventions, in all fields of technology, provided that they are new, involve an inventive step and are susceptible of industrial application (Article 52 (1) EPC), and disclose the invention in a manner sufficiently clear and complete for it to be carried out by a person skilled in the art (Article 83 EPC). In the US, patents are awarded for any new and useful process, machine, manufacture, or composition of matter, or any new and useful improvement thereof (35 USC 101), provided that the patent specification contains a written description of the invention in such full, clear, concise, and exact terms as to enable any person skilled in the art to which it pertains, to make and use the same, thereby setting forth the best mode contemplated by the inventor of carrying out his invention (35 USC 112).

In what follows, we will examine how legislators and courts have modulated the basic requirements for patent acquisition - patentable subject matter, novelty, inventive step/nonobviousness, industrial applicability/utility, enabling disclosure - to accommodate inventions in the field of biotechnology.

\subsubsection{Patentable subject matter - inventions and discoveries}

In general

In the US, the Utility Patent Act (UPA) defines subject matter eligibility in a positive way focusing on classes of invention - and leaves the exclusions to the courts. The EPC develops a positive approach - focusing on the invention concept - and immediately adds a series of negative definitions and exclusions. The EPC sets forth that some subject matter "shall not be regarded as inventions" (Article 52 (2) EPC). Both the US and European approaches are permissible under the TRIPs Agreement, setting forth that "Members may exclude from patentability" certain inventions (Article 27 (2) and (3) TRIPs Agreement).

Defining patentable subject matter under US patent law, circles around statutory subject matter categories. According to US patent law, patent protection can only be awarded when the invention falls within at least one of the four classes of statutory subject matter: processes, machines, manufactures or compositions of matter (35 USC 101). Over the years, wide attention has been paid to the exact scope of the "great and distinct classes". 42 In 1980 the debate came to an end, when the Supreme Court interpreted these statutory classes expansively to encompass "anything under the sun that is made by man" (Diamond vs. Chakrabarty). ${ }^{43}$ In US patent law, far less attention has been attributed to the interpretation of the term 'invention'. The UPA indicates that the term invention means "invention or

${ }^{42}$ Ex parte Blythe, 1885 Comm'n Dec. 82, 86.

${ }^{43}$ Diamond vs. Chakrabarty, 447, US 303, 309 (Supreme Court, 1980). 
discovery" (35 USC 100), providing little help on the issue. Courts and commentators have labored to settle on a universally applicable definition. ${ }^{44}$ It has been suggested that any inquiry into patentable subject matter should look into "the essential characteristics of the subject matter, in particular, its practical utility". ${ }^{45}$

Outlining patentable subject matter under European patent law, revolves around the notion of invention: European patents shall be granted for any inventions provided that they are new, involve an inventive step and are susceptible of industrial application (Article 521 EPC). The EPC, however, does not provide a definition of this key concept and does not expressly define what an invention is. The EPC Implementing Regulations hint at the technical character of an invention, when they prescribe that the description shall specify the technical field to which the invention relates (Rule 42 (1) (a) EPC IRs), that the description shall disclose the invention, as claimed, in such terms that the technical problem, even if not expressly stated as such, and its solution can be understood (Rule 42 (1) (c) EPC IRs) and that the claims shall define the matter for which protection is sought in terms of the technical features of the invention (Rule 43 (1) EPC IRs). The Technical Boards of Appeal from their side take the view that the use of the term invention in article 52 (1) EPC, read in conjunction with the list of so-called non-inventions or "Nicht Erfindugen" 46 in article 52 (2) and (3) EPC, implies a requirement of technical character or technicality which is to be fulfilled by an invention as claimed in order to be patentable. An invention may be an invention within the meaning of article 52(1) EPC if, a technical effect is achieved by the invention or if technical considerations are required to carry out the invention. The term 'invention' is to be construed as subject matter having technical character and having technical character is an implicit requirement of the EPC to be met by an invention in order to be an invention within the meaning of Article 52(1) EPC. ${ }^{47}$

\section{In biotechnology}

In the US, the debate on eligible subject matter in the realm of biotechnology was recently reopened. Exactly thirty years after the trendsetting Chakrabarty decision, the Federal District

\footnotetext{
${ }^{44}$ See Manya S. Deehr \& William C. Rooklidge, The Stage of Development of an Invention Subject to the OnSale Bar to Patentability, re-printed in Donald Chisum, Craig Allen Nard, Herbert F. Schwarz, Pauline Newman \& F. Scott Kieff, Principles of Patents Law. Cases and Materials, New York, Foundation Press (2004), p. 380. Also see Paul M. Janicke, The Varied Meanings of Invention in Patent Practice: Different Meanings in Different Situations, in Dunner, Gambrell and Kayton, Patent Law Perspectives (1970).

${ }^{45}$ State Street Bank and Trust vs. Signature Financial Group, Inc. 149 F. 3d 1368, 1375 (Fed. Cir. 1998).

${ }^{46}$ Rainer Moufang, Kommentierung des Europäischen Patentübereinkommen. Artikel 53: Ausnahmen von der

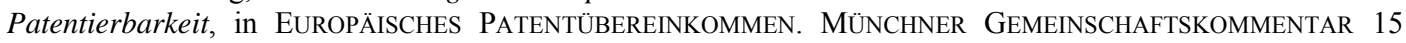
(1991).

${ }^{47}$ EPO Technical Board of Appeal (T 931/95), 8 September 2000, OJ EPO, 2001, 441 (Pension Benefit Systems Partnership) relating to EP 332.770. The Board agrees with the appellant that in order to be patentable there is not an explicit requirement of technical character of an invention under Article 52 EPC or under any other provisions of the EPC which is concerned with substantive patent law. Article $52 \mathrm{EPC}$, in particular in its paragraph 1, only makes it clear that for something to be patentable, it must be an invention. However, having regard to the case law of the Boards of Appeal and taking into account the frequent use of the term "technical" in the EPC and the Implementing Regulations, which are an integral part of the EPC, and having due regard to the context in which the term "technical" is used there, the Board is of the opinion that the requirement of technical character is inherent to the notion "invention" as it occurs in Article 52(1) EPC. Thus the Board concludes that having technical character is an implicit requirement of the EPC to be met by an invention in order to be an invention within the meaning of Article 52(1) EPC, following decisions T 1173/97 and T 935/97 (Point 6 of the Reasons).
} 
Court of New York ruled that genes are to be regarded as discoveries and should be excluded from patentability. ${ }^{48}$ Is the pendulum swinging back in biotechnology? ${ }^{49}$

The EPC invention concept and the requirement of technical character, has had a clear influence in the field of biotechnology, especially when the patentability of DNA was discussed. Some scholars took the view that DNA was an element of nature which had to be regarded as a discovery, and was therefore not patentable (Article 52 (2) (a) EPC). Others argued that DNA was an invention as it required technical skill and human intervention to isolate it from its natural environment.

The heated discussion on the discovery nature of DNA was resolved by the EUBiotechnology Directive, stipulating "that biological material which is isolated from its natural environment or produced by means of a technical process even if it previously occurred in nature" shall also be patentable (Article 3 (2) Directive; Rule 27 (a) EPC IRs). With regard to DNA sequences, the Directive stipulated more in particular that "the human body, at the various stages of its formation and development, and the simple discovery of one of its elements, including the sequence or partial sequence of a gene, cannot constitute patentable inventions" (Article 5 (1) Directive; Rule 29 (1) EPC IRs), whereas "an element isolated from the human body or otherwise produced by means of a technical process, including the sequence or partial sequence of a gene, may constitute a patentable invention, even if the structure of that element is identical to that of a natural element" (Article 5 (2) Directive; Rule 29 (2) EPC IRs). This approach, introducing a distinction between (unpatentable) discoveries and (patentable) inventions in the field of DNA research has been fiercely criticized. However, the EU and the EPO maintain the distinction between DNA in nature, which is considered a discovery and isolated DNA which can amount to an invention thanks to a technical intervention.

\section{Policy lever}

The technical character rule is a micro policy lever, applying to inventions in all industries, but with particular significance for certain industries, in casu biotechnology. The technical character rule and its application to DNA has consciously been employed as a policy lever to fuel innovation in the biotechnology sector. Originated as a judicial policy lever, the technical character rule is now formally embedded in the EU Biotechnology Directive, which makes it a statutory policy lever. The EU Biotechnology Directive bears strong witness of the endeavor to stimulate biotechnology innovation through recognition of biological developments as inventions. ${ }^{50}$

However, recent investigations have pointed to the potential detrimental effect all that many DNA patents may have on further research and development, and on access healthcare. The omnipresence of patents for DNA may produce an anti-commons effect, threatening rather than stimulating downstream innovation. ${ }^{51}$ At present, it is being examined to what extent

${ }^{48}$ ACLU v. Myriad, a ruling between the Association of Molecular Pathology (AMP) v. U.S. Patent and Trademark Office (USPTO).

${ }^{49}$ Cf. Kesselheim, A.S., Mello, M.M., Gene Patenting — Is the Pendulum Swinging Back? NEJM 2010

${ }^{50} \mathrm{Cf}$. for example preambles 1 and 2 of the Directive: “(1) Whereas biotechnology and genetic engineering are playing an increasingly important role in a broad range of industries and the protection of biotechnological inventions will certainly be of fundamental importance for the Community's industrial development; (2) Whereas, in particular in the field of genetic engineering, research and development require a considerable amount of high-risk investment and therefore only adequate legal protection can make them profitable".

${ }^{51}$ The alarming and trendsetting article came from Michael Heller \& Rebecca Eisenberg, Can Patents Deter Innovation? The Anticommons in Biomedical Research, 280 Science, 1998, 698-701. Since, then, a vast body of 
new models of collaborative licensing may facilitate access to gene patents and render clusters of patents more readily available for use in research and healthcare. ${ }^{52}$

\subsubsection{Patentable subject matter - morality}

\section{In general}

In US patent law, it has been suggested that the utility requirement encompasses a morality test and that it has to be examined whether the invention achieves a human purpose that is not illegal, immoral or contrary to public policy. ${ }^{53}$ In the last decades, however, the courts and the PTO have virtually abandoned the requirement that an invention is morally beneficial. ${ }^{54}$

European patent law also contains a morality test, but one that is formally and explicitly embedded in patent law. The EPC sets forth that European patents shall not be granted in respect of inventions the commercial exploitation of which would be contrary to ordre public or morality. Such exploitation shall not be deemed to be so contrary merely because it is prohibited by law or regulation in some or all of the EPC contracting states (Article 53 (a) EPC).

EPO case law indicates that the exception has to be narrowly construed. The commercial exploitation of an invention must be in conflict with ordre public or morality, not just

literature providing empirical evidence emerged. Most empirical studies focus on the issuance of human gene patents by patent authorities. See e.g. Hopkins, M.M., Mahdi, S., Patel, P. and Thomas, S., 'DNA Patenting: The End of an Era?', 25 Nature Biotechnology, 2007, 185-187; Hopkins, M.M., Mahdi, S., Patel, P. and Thomas, S., The Patenting of Human DNA: Global Trends in Public and Private Sector Activity (A Report for the European Commission - PATGEN Project $-6^{\text {th }}$ FP-2003- LifeSciHealth-II), Brighton, Science and Technology Policy Research (SPRU) - University of Sussex, 2006, 14 (available at: http://www.sussex.ac.uk/spru/documents/patgen finalreport.pdf); Huys, I., Berthels, N., Matthijs, G. And Van Overwalle, G., 'Legal Uncertainty in the Area of Genetic Diagnostic Testing', 27, Nature Biotechnology, October 2009, 903-909; Jensen, K. and Murray, F., 'Intellectual Property Landscape of the Human Genome', 310 Science, 2005, 239-240; National Research Council of the National Academies (Committee on intellectual Property Rights in Genomic and Protein Research and Innovation), Reaping the Benefits of Genomic and Proteomic Research: Intellectual Property Rights, Innovation, and Public Health, Washington, National Academies Press, 2005, 161 p. (see www.nap.edu/catalog/11487.html); Verbeure, B., Matthijs, G. and Van Overwalle, G., 'Analysing DNA patents in relation with diagnostic genetic testing', 14 European Journal of Human Genetics (EJHG), vol. 1, January 2006, 26-33; Walsh, J.P., Cho, C. and Cohen, W. M., Patents, Material Transfers and Access to Research Inputs in Biomedical Research (Final Report to the National Academy of Sciences Committee [on] Intellectual Property Rights in Genomic and Protein-Related Research Inventions), Washington, National Academies Press, 2005, 172 p. Also see Ben Depoorter \& Sven Vanneste, Putting Humpty Dumpty Back Together: Experimental Evidence of Anticommons Tragedies, 3 Journal of Law, Economics \& Policy, 1-25. Some empirical studies focus on gene patents that have been asserted in court to assess the actual restrictive effect of patents. See e.g. Holman, C.M., 'The Impact of Human Gene Patents on Innovation and Access: A Survey of Human Gene Patent Litigation', 76 University of Missouri-Kansas City Law Review, 2007, 295-362. Also see Ann E Mills \& Patti Tereskerz, DNA-based patents: an empirical analysis, 26 Nature Biotechnology, 2008, 993-995.

${ }^{52}$ See Geertrui Van Overwalle, Of Thickets, Blocks and Gaps: Designing Tools to Resolve Obstacles in the Gene Patents Landscape, in Gene Patents and Collaborative Licensing Models. Patent Pools, Clearing Houses, Open Source Models and Liability Regimes, Geertrui Van Overwalle (ed.), Cambridge, Cambridge University Press, 2009, 381-463.

${ }^{53}$ Chisum on Patents, $\S 4.01$ (check!). The unpatentability of immoral subject matter seems to have originated with Justice Story's opinion in Bedford v. Hunt, 3.F. Cas. 37, 37 (C.C.D. Mass. 1817), see Chisum D.S. et al., reference footnote $51,750-751$.

${ }^{54}$ Chisum, D.S. et al, see reference in previous footnote, 751. Also see Burk \& Lemley, The Patent Crisis, 2009, 111 and the court decisions cited in footnote 2 and the patents cited in footnote 6; Robert P. Merges, Intellectual Property in Higher Life Forms: The Patent System and Controversial Technologies, 47 Md. L. Rev. 469 (1988). 
prohibited by statutory law. ${ }^{55}$ In other words, being forbidden by law and creating a possible conflict with simple statutory law, does not suffice to lead to a rejection under article 53 (a) EPC.

\section{In biotechnology}

In the US, morality hardly seems to have played a role in biotechnology patenting The American Supreme Court explicitly stated in the Chakrabarty case that it is not competent to rule on ecological and ethical matters and that such issues should be addressed by the political branches of government, i.e. the Congress and the Executive, and not by the courts. ${ }^{56}$ Only recently, Congress intervened and explicitly prohibited issuing patents for genetically modified humans. ${ }^{57}$

In Europe, the morality clause figured discretely in patent law without causing a great stir for quite some time. With the advent of biotechnology, however, the morality clause rigorously stepped into the limelight. ${ }^{58}$ It was felt that the ambivalence of biotechnology made the necessity of ethical monitoring more urgent. Although the confrontation of ethics and patent law is difficult, to say the least, and usually ethics are seen in this context as a disturbance - as the grosse Störung ${ }^{59}$ - the ethical assessment of biotechnological inventions and related patents has always been high on the agenda in Europe.

Initially, the ethical debate took place at the EPO level, article 53 (a) EPC being the sole yardstick available to guide the EPO in delicate questions on the patentability of living material. ${ }^{60}$ Long after the first patents for human genes had been granted in the context of recombinant DNA technology as a matter of routine, ${ }^{61}$ the morality of gene patents became an issue. The ethics of gene patenting was fiercely debated when a patent coding for human

${ }^{55}$ Rainer Moufang, The Concept of 'Ordre Public' and Morality in Patent Law, in Octrooirecht, ethiek en biotechnologie - Patent Law, Ethics and Biotechnology, Geertrui Van Overwalle (ed.), Brussel, Bruylant, 1998, 65-77.

${ }^{56}$ Geertrui Van Overwalle, Biotechnology Patents in Europe. From Law to Ethics, in Biotechnology, Patents and Morality, Aldershot, Ashgate, 1997, 139-148.

${ }^{57}$ See, Burk \& Lemley, The Patent Crisis, 2009, 96.

${ }^{58}$ An interesting table for comparison is provided by WIPO, listing subject matter which has been excluded in the past - partly - on the basis of public interest lever or the product of nature doctrine: 44/92 countries excluded pharmaceutical products from their field of patent protection; 42/92 biological methods. 44/92 therapeutic methods; 35/92 food; 22/92 chemical compounds (Existence, Scope and Form of Generally Accepted and Applied Standards/Norms for the Protecting of Intellectual Property, September 1988 (DOC WIPO/INF/29).

${ }^{59}$ See Geertrui Van Overwalle, Biotechnology Patents in Europe. From Law to Ethics, in Biotechnology, Patents and Morality, Aldershot, Ashgate, 1997, 139-148.

${ }^{60}$ The morality clause triggered reflection and debate in some adjacent areas as well, such as informed consent and traditional knowledge. These issues will not be discussed here. For more, see Geertrui Van Overwalle, Biotechnology and Patents: Global Standards, European Approaches and National Accents, in Genetic Engineering and the World Trade System, Daniel Wüger and Thomas Cottier (eds.), Cambridge University Press, 2008, 77-108.

${ }^{61}$ European patents have been granted for the majority of recombinant DNA achievements. Thus, a European patent was issued for the production of alpha-type interferon, gamma-type interferon, clotting factor Factor VIII, tissue-type plasminogen activator or t-PA, erythropoietin (EPO), et al. A good example in this connection is the patent granted for alpha-type interferon. An examination of the description and patent claims of the interferon patent reveals that protection was granted for a well-defined DNA sequence, a recombinant DNA molecule, a host transformed with said recombinant DNA molecule, an alpha-type interferon produced by said transformed host, for a process for producing the recombinant DNA molecules, a process for the transformation of the host and a process for the production of an alpha-type interferon. For details, see Geertrui Van Overwalle, The Legal Protection of Biotechnological Inventions in Europe and in the United States. Current Framework and Future Developments, in Leuven Law Series, Leuven, University Press, 1997, 78 p. 
relaxin was granted (Howard Florey Institute case). ${ }^{62}$ On opposition, the EPO Opposition Division concluded that an invention concerning a human gene was not an exception to patentability "because it would not be universally regarded as outrageous: it did not amount to patenting life because DNA as such was not life but one of the many chemical entities participating in biological processes, and no offence to human dignity had occurred as the woman who donated tissue was asked for her consent and her self-determination was not affected by the exploitation of the claimed molecules". ${ }^{63}$ The EPO Technical Boards of Appeal later confirmed the Opposition point of view and concluded that the human gene patent claim was allowable. ${ }^{64}$

The question of morality and plants came up with the grant of a patent on a genetically modified plant (Lubrizol case). ${ }^{65}{ }^{66}$ On opposition, the EPO Opposition Division decided that the exclusion of patentability in article 53 (a) EPC for inventions which are contrary to public order and morality, only concern extreme cases which are universally regarded as abhorrent. In view of the consideration that the actual patent related to an invention which might be used for creating new plants the nutritive value of which is increased in comparison with conventionally obtained plants, and that the plants covered by said patent might give rise to a better management of food shortage in the world, the Opposition Division ruled that the exploitation of such an invention could not therefore be considered immoral or against public order and decided that a violation of article 53 (a) EPC was not apparent. ${ }^{67}$ In a later plant patent case (Plant Genetic Systems) ${ }^{68}$, the Opposition Division reached a similar decision. ${ }^{69}$ On appeal, the Technical Board of Appeal specified the twin concept ordre public and morality in the latter case. The Board set forth that the concept of ordre public covers the protection of public security and the physical integrity of individuals as part of society, and the protection of the environment. ${ }^{70}$ The Board added that the concept of morality is related to the belief that some behavior is right and acceptable, whereas other behavior is wrong, this

\footnotetext{
${ }^{62}$ European patent 112.149 (B1), awarded April 101991 to Howard Florey Institute of Experimental Physiology and Medicine, entitled "Molecular cloning and characterization of a further gene sequence coding for human relaxin". Granted claim 1 reads as follows: "1. A DNA fragment encoding human H2-preprorelaxin, said H2preprorelaxin having the amino-acid sequence set out in Figure 2".

${ }_{63}^{63}$ EPO Opposition Division, 18 January 1995, OJ EPO, 1995, 388.

${ }^{64}$ EPO Technical Board of Appeal (T 0272/95), 23 October 2002. To assess the validity of the arguments put forward, article 53 (a) EPC was interpreted in the light of (the then implemented) Article 5 EU-Biotechnology Directive (Rule 29 EPC IRs).

${ }^{65}$ European patent 122.791 (B1) awarded on March 291989 to Lubrizol Genetics Inc entitled "Plant Gene Expression". Granted claim 10 reads as follows: "10. A method for genetically modifying a plant cell, comprising the steps of: (a) inserting a plant gene comprising a plant promoter and a plant structural gene into 1DNA, thereby forming a T-DNA/plant gene combination, the plant promoter being adjacent to the 5 '-end of the plant structural gene and the plant structural gene being downstream from the plant promoter in the direction of transcription; and (b) transferring the T-9HA/plant gene combination into a plant cell.). Granted claim 19 reads as follows: "A plant, a plant tissue, or a plant cell produced according to the method of any of Claims 10-18".

${ }^{66}$ The present study only discusses the possible exclusion of transgenic plants on morality grounds, and will not enter into the complex legal-technical debate on the exclusion of plant varieties. For an in depth analysis of that debate, and the current state of play, see VAN OVERWALLE, G., 'Patent Protection for Plants: a Comparison of American and European Approaches', 39 IDEA-Journal of Law and Technology (USA), 1999, 143-194. Also see the decisions of the EPO Technical Board of Appeal (T 1054/96), 13 October 1997 (Novartis), OJ EPO, 1998, 511; EPO Enlarged Board of Appeal (G 1/98), 20 December 1999 (Novartis), OJ EPO, 2000, 111-141; EPO Technical Board of Appeal (T 1054/96), 6 December 2000 (Novartis).

${ }^{67}$ EPO Opposition Division, March 311992.

${ }^{68}$ European patent 242.236 (B1) awarded on October 101990 to Plant Genetic Systems entitled "Plant cells resistant to glutamine synthetase inhibitors, made by genetic engineering".

${ }^{69}$ EPO Opposition Division, December 15 1992, IIC, 1993, 618.

${ }^{70}$ EPO Technical Board of Appeal (T 356/93), February 211995 (Appeal on the decision of the Opposition Division, December 15 1992). See Point 5 of the aforementioned decision, OJ EPO 1995, (545), 557. Cf. Point 14 of the Reasons, OJ, 1995, (545), 560.
} 
belief being founded on the totality of the accepted norms which are deeply rooted in a particular culture. ${ }^{71}$ The Board concluded that the evidence provided by the appellant did not lead to the definite conclusion that the exploitation of the invention would seriously prejudice the environment and run counter to ordre public ${ }^{72}$ and that plant biotechnology per se cannot be regarded as being more contrary to public morality than traditional selective breeding. ${ }^{73}$

The issue of ethics and animals was heavily discussed with the (first refused, but later granted) patent for a transgenic mouse (Harvard/Onco Mouse case). ${ }^{74}$ The Technical Board of Appeal clearly stated that for each individual invention the question of morality had to be examined and possible detrimental effects and risks had to be weighed and balanced against the merits and advantages aimed at. ${ }^{75}$ On further proceedings, it was confirmed that in the present case, the medical benefit outweighed the harm caused. ${ }^{76}$

The prevailing EPO viewpoints on ethics and bio-patenting were later consolidated by the EU legislator in the EU Biotechnology Directive. First and foremost, the Directive recognizes the EPO policy on human gene patenting by explicitly confirming the patentability of human genes (Article 5 Directive). Furthermore, the Directive formally copied the EPC morality clause (Article 6 (1) Directive) and additionally provided a non-exhaustive list of inventions which shall be considered unpatentable for ethical non-compliance: processes for cloning human beings, processes for modifying the germ line genetic identity of human beings, uses of human embryos for industrial or commercial purposes and processes for modifying the genetic identity of animals which are likely to cause them suffering without any substantial medical benefit to humans or animals and also animals resulting from such processes (Article 6(2) Directive). By well deliberating which exceptions to include and not, the Directive enshrined the EPO approach with regard to transgenic plants (allowable, hence not listed) and transgenic animals (allowable, after a case by case balancing act, hence listed).

Somewhat unfortunate, some issues remained unclear under the EU Biotechnology Directive. ${ }^{77}$ One of the outstanding issues relates to human embryonic stem cell patents. With the ascendancy of stem cell technology, the question has arisen whether stem cells of human origin can be considered patentable. To what extent does Article 5 of the Directive apply to human stem cells and what guidance can be found in Article 6 of the Directive? ${ }^{78}$ The EPO became the focal level for guidance again and recently concluded (Thomson case) ${ }^{79}$ that the

\footnotetext{
${ }^{71}$ See Point 6 of the Reasons of the aforementioned decision, OJ EPO, 1995, (545), 557.

${ }^{72}$ See Point 18.6 of the Reasons of the aforementioned decision, OJ EPO, 1995, (545), 566.

${ }^{73}$ See Point 17.1 of the Reasons of the aforementioned decision, OJ EPO, 1995, (545), 562.

${ }^{74}$ European patent 169.672 (B1) awarded on May 151992 to The President and Fellows of Harvard College entitled "Method for producing transgenic animals".

${ }^{75}$ Technical Board of Appeal (T 19/90), October 3 1990, OJ EPO, 1990, 476; Examining Division, April 31992, OJ EPO, 1992, (588), 591

${ }^{76}$ Without discussing this case in too much detail, it is relevant to note that on the basis of the morality clause, as worded Article 6 of the EU Biotechnology Directive and operationalized in the EPC (through its Implementing Regulations), the Opposition Division limited the patent to rodents (Opposition Division, November 7 2001), and that the Technical Board of Appeal further limited the patent to transgenic mice (Technical Board of Appeal, T 0315/03, July 6 2004).

${ }^{77}$ For a discussion, see Geertrui Van Overwalle, Legal and Ethical Aspects of Bio-Patenting: Critical Analysis of the EU Biotechnology Directive, in P. Drahos (ed.), Death of Patents (Witney: Lawtext Publishing, 2005), pp. 212-27.

${ }^{78}$ See.

${ }^{79}$ European patent application EP19960903521 (with publication no 770.125), submitted by Wisconsin Alumni Research Foundation (WARF) on January 20 1995, entitled "Primate embryonic stem cells". Claim 1 of the patent application reads "1 A cell culture comprising primate embryonic stem cells which (i) are capable of proliferation in vitro [sic] culture for over one year, (ii) maintain a karyotype in which all chromosomes normally characteristic of the primate species are present and are not noticeably altered through culture for over
} 
morality clause forbids the patenting of claims directed to products which at the filing date could be prepared exclusively by a method which necessarily involved the destruction of the human embryos from which the said, products are derived, even if the said method is not part of the claims. ${ }^{80}$

\section{Policy lever}

In Europe, in principle any invention in whatever field of technology has to eligible under the ethical rule. However, the morality rule is much more put to test in biotechnology than in other industries. As a result, in Europe morality functions as a significant restriction on patenting in biotechnology. The morality doctrine therefore is a micro policy lever that is applied to exclude patents for certain life forms. Initially proclaimed in the EPC, the morality doctrine was further developed by the Opposition Division and the Technical Boards of Appeal of the EPO, turning the doctrine into a judicial micro policy lever. Later onwards, the EPO case law was embedded in biotechnology specific statutes, namely the EU Biotechnology Directive, thus shaping the doctrine as a statutory policy lever.

Patent law should undoubtedly take into account ethical concerns and pay special attention to the admissibility of patents for human life forms, in view of the principles of human dignity and non-commodification. However, patent law should only do so to the extent that it concerns matters directly and inextricably linked with patents and the exercise of patent rights. In this regard, the question arises whether the list of exclusions of article 6(2) Directive should be taken up in patent law, as it does not seem to aim to limit the patent implications of certain biotech inventions, but rather wishes to exclude certain fields of research as such. Patent law should not interfere when research is ethically undesirable. Since a direct link is missing in article 6 (2) between ethics and patents, it might be contemplated to abolish this provision and to take up these exclusions in research regulations. ${ }^{81}$ So, the plea is not to abandon the morality clause, but rather to (re)direct it to its initial goal, namely the exclusion of inventions, the commercial exploitation of which runs counter to ordre public and morality.

\subsubsection{Patentable subject matter - medical methods}

\section{In biotechnology}

A rule that only bears special significance in biotechnology in relation to health care, and for which no US counterpart could be uncovered, is the medical method rule. The EPC puts forward that European patents shall not be granted in respect of methods for treatment of the

one year, (iii) maintain the potential to differentiate to derivatives of endoderm, mesoderm, and ectoderm tissues throughout the culture, and (iv) are prevented from differentiating when cultured on a fibroblast feeder layer". The Examining Division decided on 13 July 2004 to refuse said patent application.

${ }^{80}$ Enlarged Board of Appeal (G 0002/06), 25 November 2008 (referral from the Technical Board of Appeal, T 1374/04, OJ EPO 2007, 313). There is a vast amount of literature on this case and on human stem cells in general. See e.g. Aurora Plomer and Paul Torremans, Embryonic Stem Cell Patents: European Patent Law and Ethics, Oxford, Oxford University Press, 2009; Geertrui Van Overwalle, Study on patents relating to human stem cell research, Brussels, European Commission - European Group on Ethics in Science and New Technologies (EGE), 2001; Geertrui Van Overwalle, Patenting Stem Cell Research in Europe and in the United States, in Crossing Borders. Cultural, Religious and Political Differences Concerning Stem Cell Research, W. Bender, C. Hauskeller and A. Manzei (eds.), Münster, Agenda Verlag, 2005, 519-546. On the question of the applicability of Rule 28 (c) EPC IRs the Enlarged Board answered that the rule applied to all pending applications, including those filed before it entered into force

${ }^{81}$ Geertrui Van Overwalle, previous footnote . 
human or animal body by surgery or therapy and diagnostic methods practiced on the human or animal body, which shall not apply to products, in particular substances or compositions, for use in any of these methods (Article 53 (c) EPC). Medical methods are not excluded because they are not considered inventions, as is the case with subject matter listed under Article 52 (2) EPC. Medical methods can be qualified as inventions but are carved out from patent law as a matter of policy, in a concern to ensure that those who carry out such methods as part of the medical treatment of humans or the veterinary treatment of animals are not inhibited by patents. ${ }^{82}$

\section{Policy lever}

The medical method exception was prompted by a clear concern about guaranteeing access to life saving treatments. This approach undoubtedly aimed at having effect in a very specific industry sector, namely health care. Expressly implementing the medical method approach into patent legislation, makes it a statutory macro policy lever.

However, the restrictive manner in which the exclusion has lately been implemented in the field of genetic diagnostics - allowing patents on diagnostic methods for testing early onset breast and ovarian cancer based on the genes BRCA1 and BRCA2 awarded to the US company Myriad Genetics - led to some fierce debates about the perceived limited scope of article 53 (c) EPC. ${ }^{83}$ It should be noted, however, that the criticism voiced in the BRCA case was not always directed towards the grant of patents on genes and related diagnostic methods, but also to the restrictive licensing policy of the patent owners and their business strategy to maximize profit. ${ }^{84}$ In Europe, one response to address undesirable effects and unreasonable behavior from patent holders has been the introduction of the compulsory license for public health. ${ }^{85}$

\subsubsection{Novelty - first and second medical use}

\section{In general}

Most patent systems require that an invention is new in order to be eligible for patent protection. US patent law stipulates that whoever invents or discovers any new and useful process, machine, manufacture, or composition of matter, or any new and useful improvement thereof, may obtain a patent therefore (35 USC 101). In the same line, European patent law

\footnotetext{
${ }^{82}$ The same policy argument was deployed under the initial EPC 1973 counterpart from this exclusion (then Article 52 (4) EPC), but a different legal technique was employed to achieve the policy objective at hand. The 1973 legislator, followed by the Technical Boards of Appeal, implicitly recognised that medical methods are susceptible of industrial application as a matter of reality, but "shall not be regarded as" inventions which are susceptible of industrial application, by way of legal fiction (See T 116/85, OJ EPO 1989, 13). In an attempt to openly recognize the underlying policy rational of the exclusion of medical methods, the exclusion for medical methods was rephrased and replaced as Article 52 (3) (c) EPC by the EPC Revision Act in 2000. For more details, see Daniel Thomas, 'Patentability Problems in Medical Technology', IIC, 2003, 847-994. Also see Geertrui Van Overwalle, IPR Issues and High Quality Genetic Testing, in Quality Issues in Clinical Genetic Services, U. Kristoffersson, J. Schmidtke, \& J.-J. Cassiman (eds.), Springer, 2010 and the references cited there.

${ }^{83}$ See VAN OVERWALLE, G. (ed.), Gene Patents and Public Health, Brussel, Bruylant, 2007, 241 p. and the references cited there.

${ }^{84}$ A lot has been published on the Myriad BRCA saga. The interested reader might take note of the following background publication: Gold, Richard and Carbone, Julia, Myriad Genetics. In the Eye of the Policy Storm, International Expert Group on Biotechnology, Innovation and Intellectual Property, September 2008. Also see Geertrui Van Overwalle, previous footnotes.

${ }^{85}$ See below, section 2.3.2.
} 
prescribes that European patents shall be granted for any inventions, in all fields of technology, provided that they are new, involve an inventive step and are susceptible of industrial application (Article 52 (1) EPC), and that an invention shall be considered to be new if it does not form part of the state of the art (Article 54 (1) EPC).

Following from this general principle, patent protection can be awarded for a substance or composition that is new. Conversely, patent protection can not be granted for a substance when the substance is not new, but only the use or application of that substance is new. The substance is part of the state of the art and a novel use of a known substance does not modify the prior art status of said substance or composition.

\section{In medicine}

In the medical field, however, European patent law applies a divergent rule when it comes to the use of substances and compositions that are already part of the state of the art. When such a known substance or composition is used for the very first time in a surgical, therapeutic or diagnostic method - in other words when the use of such substance is new for such methods patent protection can be granted for the use in one of such methods. The EPC explicitly stipulates that the general anticipation rules "shall not exclude the patentability of any substance or composition, comprised in the state of the art, for use in a method referred to in Article 53 (c) EPC [surgical, therapeutic or diagnostic method], provided that its use for any such method is not comprised in the state of the art". ${ }^{86}$

EPO jurisprudence has extended this diverging rule to known substances which are used for second and further medical indications. At various occasions, the Enlarged Board of Appeal indeed clarified the question whether and in what way a known medicament for the treatment of a specific illness can be protected for the treatment of other illnesses. The Enlarged Board stated that it is legitimate to allow "claims directed to the use of a substance or composition for the manufacture of a medicament for a specified new and inventive therapeutic application, even in a case in which the process of manufacture as such does not differ from known processes using the same active ingredient". ${ }^{87}$ Recently, this case law was codified and the EPC now clearly states that the general anticipation rules shall not foreclose "the patentability of any substance or composition for any specific use in a method referred to in Article 53 (c) EPC [surgical, therapeutic or diagnostic method], provided that such use is not comprised in the state of the art" (Article 54 (5) EPC). In this way it is formally confirmed that also the second and further medical use of known substances or compositions are patentable. Most member states have adapted their national patent acts accordingly.

Last but not least, EPO jurisprudence looked into the question whether use claims are also permissible in non-medical fields. Imagine the use of a chemical compound, for example, not as a growth regulator, which is known, but as a fungicide, which is not known yet. ${ }^{88}$ The Enlarged Board stated that the patentability of a second non-medical use of a product is already recognized in principle in the cases concerning the second medical use of a

\footnotetext{
${ }^{86}$ For an in-depth analysis of the EPO case law on first medical indication, see European Patent Office, Case Law of the Boards of Appeal of the European Patent Office, Munich, EPO, 2006, 101-104 (further abbreviated as EPO, Case Law of the Boards of Appeal, 2006). Also see Margarete Singer \& Dieter Stauder, European Patent Convention. A Commentary, Thomson-Sweet \& Maxwell-Heymanns, 2003, p. 127-128. previous footnote

${ }^{87}$ EPO Enlarged Board of Appeal (G 5/83), December 5 1984, OJ EPO, 1985, 64, par. 23. For an analysis of the case law on second and further medical use, see EPO, Case Law of the Boards of Appeal, 2006, 104-113. Also see Margarete Singer \& Dieter Stauder, European Patent Convention. A Commentary, Thomson-Sweet \& Maxwell-Heymanns, 2003, p. 128-130. previous footnote

${ }^{88}$ This question was at stake before the EPO Technical Board of Appeal (T 231/85), 8 December 1986, OJ EPO, 1989, 74. For similar cases, see Margarete Singer \& Dieter Stauder, European Patent Convention. A Commentary, Thomson-Sweet \& Maxwell-Heymanns, 2003, p. 130-131. previous footnote
} 
substance. ${ }^{89}$ However, in those earlier decisions the exclusion from patentability of therapeutic and diagnostic methods had caused the Enlarged Board to allow only a special type of claim. These specific difficulties do not arise in the non-medical field; there the question is of a general nature, concerned primarily with the question of interpretation of the general rules governing novelty. ${ }^{90}$

\section{Policy lever}

In current European patent law, the novelty assessment rules have been adapted to stimulate further research on the use of known medicaments in cases where surgical, therapeutic and diagnostic methods have been excluded from patentability (Article 53 (c) EPC)). The EPC has introduced rules, in respect of substances and compositions used in surgical and therapeutic treatment and in diagnostic processes carried out on humans and animals, a special concept of novelty unknown in other technical fields. Novelty assessment has been specially shaped to accommodate innovation in the pharmaceutical industry. ${ }^{91}$ The first medical use rule can be considered as a statutory macro policy lever. The second medical use rule, initially shaped as a judicial extension of the first medical use doctrine, is now embedded in the EPC, thus acting as a statutory macro policy lever in European patent law.

\subsubsection{Novelty - selection invention}

\section{In general}

In many patent systems, such as the European system, selection inventions are considered patentable. Generally speaking, a selection invention is the invention of a more specific technical teaching than the general one that has already been disclosed, or, put differently, a selection invention is an invention that is a selection from a previous disclosure. Selection inventions can constitute a substantial and non-obvious enrichment of technology and are therefore acknowledged as being worthy of patent protection.

The recognition of selection inventions calls for particular care with regard to the assessment of novelty and inventive step. Indeed, if all more specific technical teachings were to be regarded as disclosed by the general teaching, selection inventions would be excluded from patent protection, for the selection invention would be regarded as lacking novelty. ${ }^{92}$ In that regard, the EPO Guidelines set forth that a generic disclosure does not anticipate the novelty of a specific example that falls within the terms of that disclosure, but a specific disclosure does take away the novelty of subject matter claimed generically, e.g. a disclosure of copper destroys novelty of metal as a generic concept, but not the novelty of any metal other than copper. ${ }^{93}$ EPO case law has repeatedly confirmed this approach. ${ }^{94}$

\section{In chemistry}

\footnotetext{
${ }^{89}$ EPO Enlarged Board of Appeal (G 5/83), 5 December 1984, OJ EPO 1985, 64.

${ }^{90}$ EPO Enlarged Board of Appeal (G 2/88), 11 December 1989, OJ EPO 1990, 93 and EPO Enlarged Board of Appeal (G 6/88), 11 December 1989, OJ EPO1990, 114).

${ }^{91}$ See EPO Enlarged Board of Appeal (G 5/83) where the Board noted that ".. [...] the Technical Board of Appeal rightly stressed its importance, particularly for the pharmaceutical industry".

${ }^{92}$ For some literature on this issue, see Margarete Singer \& Dieter Stauder, European Patent Convention. A Commentary, Thomson-Sweet \& Maxwell-Heymanns (2003), 118- 124 and the references cited there. previous footnote

${ }^{93}$ EPO Guidelines (2010), Part C - Chapter IV - 9.5

${ }^{94}$ For an overview of relevant case law, see EPO, Case Law of the Boards of Appeal, 2006, p. $87 \mathrm{ff}$.
} 
Although there are no specific limitations on the types of protectable selection inventions, in practice selection inventions appear mainly in the chemical field. ${ }^{95}$ In European patent law and practice, two types of selection inventions are quite common in the chemical field: chemical substances and groups of substances in respect of general formulae (so-called Markush formulae) under which they fall, on the one hand, and products or processes defined by parameter ranges as against known products or processes characterized by wider or overlapping parameter ranges, on the other hand. ${ }^{96}$ The Technical Boards of Appeal have developed considerable case law on the novelty assessment for both types of selection inventions in the field of chemistry, and have thoughtfully developed criteria for selection inventions. $^{97}$

\section{Policy lever}

In further shaping the novelty (and inventive step) requirement(s) for selection inventions for example in deciding how broad or generic the prior disclosure is, how narrowly the selection invention is defined, how far removed from any specific examples disclosed in the prior art the selection invention is, whether the features of the selection invention have been explicitly or implicitly described in the prior art ${ }^{98}$ - the selection invention doctrine can act as a judicially created micro policy lever, nominally applying to all inventions, but having major effects for specific industry sectors, namely the chemical and pharmaceutical field. It remains to be seen if, and if yes, to what extent, this doctrine will stretch out to the biotechnology sector in the future.

\subsubsection{Novelty - testing exemption}

\section{In general}

In the US novelty assessment literature experimental use plays a relevant role. ${ }^{99}$ Use or sale which takes part in the framework of a bona fide experiment is not novelty destroying and does not trigger the one-year grace period. ${ }^{100}$ In the framework of the nonstatutory experimental use, courts have looked into a variety of factors to determine whether a patentee's use is experimental, including whether the goods were sold, whether the patentee kept control over them, whether the patentee sought feedback, and whether the final product changed as a result. ${ }^{101}$

In Europe a similar novelty approach seems to apply in testing cases. ${ }^{102}$ The Technical Boards of Appeal repeatedly pointed out that a product made available for test purposes is to be

\footnotetext{
95 See AIPPI Resolution Question 209. Selection inventions - the inventi² ve step requirement, other patentability criteria and scope of protection, Buenos Aires, October 14, 2009 (see www.aippi.org). Also see AIPPI Q81 "Protection of groups of chemical substances and selection inventions" without passing a resolution on the subject.

${ }^{96}$ See EPO, Case Law of the Boards of Appeal, 2006, p. 87-88.

${ }^{97}$ See EPO, Case Law of the Boards of Appeal, 2006, p. 87-101.

${ }^{98}$ See EPO, Case Law of the Boards of Appeal, 2006, p. 87-101. Also see AIPPI Resolution Q 209, reference footnote.

${ }^{99}$ Experimental use as discussed in the present section, relates to the particular novelty approach for experiments in the framework of the patent application procedure, and not to experimental use as a defense in infringement cases.

${ }^{100}$ Burk \& Lemley, The Patent Crisis, 2009, 113.

${ }^{101}$ Burk \& Lemley, The Patent Crisis, 2009, 113.

${ }^{102}$ In addition, European patent law also foresees a special novelty treatment for inventions displayed at international exhibitions. The EPC sets forth that a disclosure of the invention shall not be taken into consideration if it occurred no earlier than six months preceding the filing of the European patent application and
} 
treated as confidential, and, hence, not novelty destroying. Sale of the product in a limited quantity is regarded as sale for test purposes, if the product is normally sold in large quantities. ${ }^{103}$ In the EPO approach it seems to be assumed that in testing cases a (explicit or tacit) confidentiality agreement existed beforehand.

\section{In medicine}

In Europe, the test exemption doctrine is employed quite regularly in the medical field. An illustrative case is the case concerning the implantation of a correction device into a patient, ${ }^{104}$ and where the Technical Board of Appeal had to decide on alleged prior use. ${ }^{105}$ The Board considered that a device having an investigational status, being implanted and tested within the restricted area of a hospital, under the responsibility of a surgeon operating within the framework of an investigator's agreement provided with a clause of confidentiality, has to be regarded as a prototype device. Even without the production of more specific evidence, the Board was of the opinion that the clinical tests performed on the device under the conduct and responsibility of a surgeon conferred on the operation as a whole an implicit obligation of confidentiality which had to be extended to the whole team involved in that operation. Neither the fact that the device was received and prepared by hospital staff, nor the fact that it was visible to the hospital staff during the operation, was suitable to prove that the device was accessible to the public. The decision was based on the reasoning of a previous Board decision where prior use was acknowledged but where the question of confidentiality was contested. ${ }^{106}$ In the latter case it was held that in the medical field there is a prima facie assumption that any person involved in a medical process is obliged to maintain confidentiality, given the need for patient confidentiality and the need to protect the development and testing of prototype devices.

\section{In microbiology}

The EPO also addressed the issue of prior testing in the field of microbiology. The Technical Board of Appeal explained that a reference to biological material in a scientific publication does not result in that biological material being considered as publicly available. ${ }^{107}$ The Board also stated that for a complex biochemical to be made available to the public, the minimum that would seem to be required for publication was a notice to those in the field that samples of the biochemical could be obtained on request, and clear evidence of exactly what the biochemical was. ${ }^{108}$

\section{Policy lever}

if it was due to the fact that the applicant or his legal predecessor has displayed the invention at an official, or officially recognised, international exhibition falling within the terms of the Convention on international exhibitions signed at Paris on 22 November 1928 and last revised on 30 November 1972 (Article 55 (1) (b) EPC). This type of non-prejudicial disclosure is not further discussed here.

${ }^{103}$ EPO Technical Board of Appeal cases T 221/91, T 267/91 and T 782/92. For a discussion of those cases, see EPO, Case Law of the Boards of Appeal, 2006, p. 61 (1.8.7.f).

${ }^{104}$ European patent 468.264 (B1) concerning a spinal column retaining apparatus awarded to Sofamor, Danek Group, Inc. v. DePuy Spine, Inc.

${ }^{105}$ EPO Technical Board of Appeal (T 906/01), September 282004.

${ }^{106}$ EPO Technical Board of Appeal (T 152/03), April 22 2004, relating to European patent 803.230 (B1) concerning an endovascular electrolytically detachable wire for thrombus formation.

${ }^{107}$ EPO Technical Board of Appeal (T 576/91), 20 October 1993, relating to European patent 235.308 (B1) concerning a coated foodstuff.

${ }^{108}$ EPO Technical Board of Appeal (T 128/92), 30 November 1994, relating to European patent 91.539 (B1) concerning active interleukin-2. 
It seems that in Europe, as well as in the US, the testing exemption doctrine is a judicial micro policy lever to accommodate inventions whose design requires testing. Such a doctrine equally applies to all inventions in all technical fields, but the effect of such a doctrine will mainly be felt in the pharmaceutical sector, where a lot of testing is necessary, and in the biotechnology sector when the shift from bench to bedside is being made.

\subsubsection{Inventive step (non-obviousness) - expectation of success}

In general

Most patent acts require that an invention is not obvious in view of the state of the art to enjoy patent protection. US patent law stipulates that a patent may not be obtained "if the differences between the subject matter sought to be patented and the prior art are such that the subject matter as a whole would have been obvious at the time the invention was made to a person having ordinary skill in the art to which said subject matter pertains" (35 USC 103 (a)).

In the same spirit, European patent law underlines that "an invention shall be considered as involving an inventive step if, having regard to the state of the art, it is not obvious to a person skilled in the art" (Article 56 EPC). The EPO Guidelines clarify that term 'obvious' refers to what does not go beyond the normal progress of technology, but merely follows plainly or logically from the prior art i.e. something which does not involve the exercise of any skill or ability beyond that to be expected of the person skilled in the art. ${ }^{109}$ Furthermore, the Technical Boards of Appeal have set forth that a course of action can be considered 'obvious' if the skilled person would have carried it out in expectation of some improvement or advantage. An illustrative example is the patent concerning the modification of a layered tablet containing simethicone and antacid. ${ }^{110}$ The Board stated that the question regarding the inventive step is not whether the skilled man could have inserted a barrier between the layers, but whether he would have done so in expectation of some improvement or advantage. Since the tablet was, on the face of it and from what was assumed in view of its commercialization, a satisfactory answer to the problem of undesirable migration, the addition of a barrier would have appeared superfluous, wasteful and devoid of any technical effect. In view of the recognition that a barrier has, after all, a substantial effect, the outcome was not predictable and the claimed modification involves an inventive step on this basis. ${ }^{111}$ In another case, it was held that obviousness is not at hand when the results are clearly predictable and when there is a reasonable expectation of success. ${ }^{12}$

\section{In biotechnology}

The EPO paid special attention to the expectation of success doctrine in the field of genetic engineering. The Technical Boards of Appeal pointedly and repeatedly examined whether it was obvious for the skilled person to try a suggested approach, route or method with a

\footnotetext{
${ }^{109}$ EPO Guidelines (2010), Part C-IV-11.4.

${ }^{110}$ European patent application with publication no 14.253 (A1) concerning a simethicone antacid tablet, refused by the EPO Examining Division on 20 July 1982.

${ }^{111}$ EPO Technical Board of Appeal (T 2/83), 15 March 1984 (Point 7 of the Reasons), OJ EPO 1984, 265.

${ }^{112}$ EPO Technical Board of Appeal (T 149/93), March 23 1995, relating to European patent application with publication no 253.393 (A1), concerning methods for treatment of sundamaged human skin with retinoids.
} 
reasonable expectation of success. ${ }^{113}$ An interesting example is the patent relating to the isolation, characterization and production of DNA molecules comprising the genes for preprochymosin. ${ }^{114}$ The Board considered that the teachings in 1981 on genetic engineering lead to the conclusion that none of the difficulties expected from the prevailing knowledge on cDNA cloning would be encountered, and that the person skilled in the art would be fairly confident at the onset of the project that the combination of these teachings and such standard knowledge on biotechnological protocols from that time ${ }^{115}$ would lead to the successful cloning of the genes encoding preprochymosin and its maturation forms. The Board concluded that it thus appeared that, at the date of priority, the cloning and expression of the chymosin DNA would have been perceived as "an endeavor likely to succeed" and that achieving this cloning did not pose such problems as to prove that this assumption was wrong. On this basis, the Board concluded that the claimed invention lacked inventive step. ${ }^{116}$ This example decision is not in contradiction with other appeal decisions in similar cases of the same time period, which acknowledged the cloning of other specific cDNA molecules as involving an inventive step, such as tissue plasminogen activator ${ }^{117}$, erythropoietin ${ }^{118}$, IFNgamma ${ }^{119}$, interleukin-II ${ }^{120}$ and human interferon ${ }^{121}$, as the actual facts of these cases were different.

So, in the field of gene technology, inventive step may be acknowledged if there is no reasonable expectation of success that the cloning and expression of a given gene can be carried out. Conversely, inventive step cannot be acknowledged in cases where, at the priority date, a skilled person can expect to perform the cloning and expression of a gene in a fairly straightforward manner, and the cloning, although requiring much work, does not pose such problems as to prove that the expectation of success was ill-founded.

\section{Policy lever}

The expectation of success doctrine as applied in Europe is a judicial micro policy lever. The characteristics of this type of obviousness test are not expressly industry specific, but produce more effect in one industry compared to another. Young industries, such as biotechnology in its early ages, where the level of uncertainty is high, are more prone to favor from this approach, compared to established industries where the level of uncertainty is low(er). Further research is needed to examine to what extent the expectation of success doctrine as employed in biotechnology in Europe, follows the theory on obviousness and uncertainty, as pioneered by Robert Merges. ${ }^{122}$ This theory suggests that where uncertainty is higher, courts should lower the standard of patentability to compensate for the risk of failure.

\footnotetext{
${ }^{113}$ EPO Technical Board of Appeal (T 60/89), August 31 1990, OJ EPO 1992, 268 relating to European patent 6.694 (B1) concerning a method of making a selected protein. For an overview of similar Board cases, see EPO, Case Law of the Boards of Appeal, 2006, 132-134.

${ }^{114}$ European patent 77.109 (B1) concerning DNA molecules comprising the genes for preprochymosin and its maturation forms, and microorganisms transformed thereby. Also see below, section 2.1.11.

${ }^{115}$ E.g. "Principles of Gene Manipulations" by R. W. Old and S. B. Primrose, Blackwell Scientific Publications, 1980, pages 59 to 88 and "Molecular Cloning, A laboratory Manual" by T. Maniatis et al., Cold Spring Harbor Laboratory, 1982.

${ }^{116}$ EPO Technical Board of Appeal (T 386/94), 11 January 1996 (Points 42 and 59 of the Reasons).

${ }^{117}$ EPO Technical Board of Appeal (T 923/92), 8 November 1995.

${ }^{118}$ EPO Technical Board of Appeal (T 412/93), 21 November 1994.

${ }^{119}$ EPO Technical Board of Appeal (T 223/92), 20 July 1993.

${ }^{120}$ EPO Technical Board of Appeal (T 128/92), 30 November 1994.

${ }^{121}$ EPO Technical Board of Appeal (T 223/92), 20 July 1993, where it was decided that the expectation of success was not likely by the method known for interferon- $\beta$.

${ }^{122}$ Robert P. Merges, Uncertainty and the Standard of Patentability, 7 High Tech. L. J., 1 (1992).
} 


\subsubsection{Inventive step (non-obviousness) - secondary indicia - commercial success}

\section{In general}

In US patent law, Graham vs. John Deere ${ }^{123}$ and $K S R^{124}$ define the standard for assessing non-obviousness, and set forth that secondary indicia can play a role therein. In European patent law, secondary indicia may equally be employed as auxiliary considerations in the assessment of inventive step in cases of doubt. Secondary indicia may encompass factors such as commercial success, the overcoming of prejudice, the age of the documents cited, the cost of advertising and the creation of a new market segment, the satisfaction of a long-standing need, the existence of imitations and forms of infringement. ${ }^{125}$ In principle, commercial success alone is not to be regarded as indicative of inventive step. Commercial success can only be taken into account if - first - a long felt need has been demonstrated, and if - second - the commercial success derived from the technical features of the invention and not from other influences (e.g. selling techniques or advertising). ${ }^{126}$

\section{In biotechnology and medicine}

There is no specific EPO case law on the application of the secondary indicia doctrine in the biotech or medical sector. Secondary indicia have not proven to be particularly relevant in the biotechnology or in the medical industry, except for one well known case, namely Viagra. Viagra is the brand name of sildenafil citrate, a substance vital in the treatment of impotence. When assessing the inventive step of the Viagra patent, ${ }^{127}$ the Board confirmed that the establishment of commercial success as an indicia of inventive step required two steps: "To establish commercial success as an indicia of inventive step requires two evidentiary steps first, to show that there has been commercial success and, second, to show that such success results from the claimed invention and not from one or more other causes. ${ }^{128}$ Viagra had been the subject of various awards and praise in various journals. The Board stated that the prizes would have been significant if awarded by persons who understand patent law for the unobvious nature of the technical contribution to the art made by the claimed invention. If

\footnotetext{
${ }^{123}$ William T. Graham, et al. v. John Deere Co. et al., 21 February 1966, 383 U.S. 1, 86 S.Ct. 684, 15 L.Ed.2d 545, 148 U.S.P.Q. 459 Check with Chisum on Patents,

${ }^{124}$ KSR International Co. v. Teleflex Inc., et al., 30 April 2007, 550 U.S. 398, 550 U.S. 398, 127 S. Ct. 1727, 82 U.S.P.Q.2d 1385. Check with Chisum on Patents The following article discusses the impact of the KSR decision on DNA-related inventions, Timo Minssen, 'The US Examination of Nonobviousness After KSR v. Teleflex with Special Emphasis on DNA-Related Inventions', ICC, 2008, 1-31.

${ }^{125}$ See EPO Technical Board of Appeal (T 1072/92), 28 June 1994, relating to European patent 291.003 concerning a hollow plag for sealing a heat exchanger tube. The Board concluded that "daß Beweisanzeichen wie die Befriedigung eines langen bestehenden Bedürfnisses, die Überwindung eines Vorurteils der Fachwelt oder ein großer wirtschaftlicher Erfolg lediglich Hilfserwägungen für die Beurteilung der erfinderischen Tätigkeit bilden. Solche Hilfserwägungen können Voraussetzung für eine positive Beurteilung der erfinderischen Tätigkeit sein, sind dies jedoch nicht zwangsläufig”. Also see the famous Epilady case, EPO Technical Board of Appeal (T 754/89), 24 April 1991, relating to European patent 101.656 (B1) concerning an electrically powered depilatory device comprising a helical spring. In this case the Board confirmed that in principle secondary indicia may be relevant to assess inventive step, but did not rely on secondary indicia in the case at stake as the inventive step could be decided on the basis of a pure technically skilled assessment.

${ }^{126}$ EPO Guidelines (2010) Part C - Chapter IV- 11.9.4. For an in-depth comparative US-EPC analysis of the subtest of commercial success, see Hanns Ullrich, Standards of Patentability for European Inventions, IIC Studies (Studies in Industrial Property and Copyright Law), Weinheim-New York, Verlag Chemie (published by the Max-Planck-Institute for Foreign and International Patent, Copright and Competition Law, Munich), 1977, 8496.

${ }^{127}$ European patent 702.555 awarded to Pfizer Ltd.

${ }^{128}$ EPO Technical Board of Appeal (T 1212/01), 3 February 2005 (Point 6.2. of the Reasons).
} 
however the prizes were awarded for the product's life-enhancing nature, or for the appellants' high standard of research, or for a high level of sales, then, for all that any of those reasons might well be prize-worthy, the prizes can have no significance in the context of inventive step. The Board arrived to the conclusion that the evidence did not establish that the "prizes and praises" resulted from the claimed inventive step. ${ }^{129}$

\section{Policy lever}

It is somewhat difficult to derive a conclusion on the basis from this one - albeit eminent EPO case in the field of medicine, as to the use of commercial success as a judicial policy lever. Further research is needed to examine to what extent the commercial success is indeed put to work as a (macro or micro) policy lever in Europe in the field of biotechnology or medicine.

\subsubsection{Industrial applicability (utility)}

\section{In general}

US patent law sets forth that whoever invents or discovers any new and useful process, machine, manufacture, or composition of matter, may obtain a patent therefore (35 USC 101). In addition, US courts have traditionally interpreted the utility requirement to mandate three separate tests: whether the invention has any purpose other than idle amusement, whether the invention actually works for its intended purpose, and whether the purpose is on that society would consider beneficial. ${ }^{130}$

Under European patent law, an invention shall be considered as susceptible of industrial application if it can be made or used in any kind of industry, including agriculture (Article 57 EPC). According to prevailing EPO case law, the industrial applicability requirement can not be equated with the requirement for a 'technical' contribution, and the terms 'industrial' and 'technical' can not be regarded as synonyms. ${ }^{131}$ The notion 'technical' is a quintessential feature of an invention, an 'invention' being the very first requirement (defined in Article 52(2) and (3) EPC) of claimed subject matter. ${ }^{132}$ The notion of 'industry', on the other hand, implies that an activity is carried out continuously, independently and for financial, commercial gain. ${ }^{133}$

\footnotetext{
${ }^{129}$ EPO Technical Board of Appeal (T 1212/01), 3 February 2005 (Points 6.3, 6.4 and 6.5 of the Reasons).

${ }^{130}$ Check with Chisum on Patents, $\S 4.01$ ?

${ }^{131}$ EPO Technical Board of Appeal (T 953/94), 15 July 1996, relating to European patent 169.703 concerning a method of functional analysis. The Board stated that the requirement (defined in Article 52(2) and (3) EPC) of claimed subject matter being a not excluded 'invention', is distinct from the requirement (defined in Article 57 EPC) of the claimed invention being 'susceptible of industrial application'. Even though the former requirement may, cum grano salis, be equated with a requirement for a 'technical' contribution, this is not the same as a requirement for an 'industrial' applicability. At least in this context, the terms 'technical' and 'industrial' are not synonyms. The Board underlines that "In Article $57 \mathrm{EPC}$, the meaning of 'industrial' is evidently intended to cover commercial applications; this is made clear, for instance, by the German version ("gewerblich"). In the context of Article 52(2) EPC, this is clearly not the case for the meaning of "technical"" (Point 3.11 of the Reasons).

132 Ibidem.

${ }^{133}$ EPO Technical Board of Appeal (T 144/83), 27 March 1986, OJ EPO 1986, 301 relating to European patent application with publication no 5.636 submitted by $\mathrm{Du}$ Pont concerning a method of improving the bodily appearance of a non-opiate-addicted mammals. The patent was refused the EPO Examining Division on the ground that, as far as the method relates to a cosmetic process, the subject matter of the claim was not susceptible for industrial application according to Article 57 EPC: the treatment of a human being with
} 


\section{In biotechnology}

In the US, the utility requirement seems to have lost much of its force in the last several decades. ${ }^{134}$ The only exceptions to the elimination of the utility requirement in US patent law can be found in the fields of biology and chemistry. The PTO's Utility Examination Guidelines indeed require that the asserted utility of the subject matter claimed is "specific and substantial, and [...] credible". ${ }^{135}$ Although the Guidelines are formulated in a technology-neutral manner, not one training example can be found outside the realm of chemistry and biotechnology. The three-fold "specific-substantial-credible"-requirement was ratified by the Federal Circuit in In re Fisher. ${ }^{136}$

In Europe, the industrial applicability requirement is very much present in the field of biotechnology. First and foremost, The EU Biotechnology Directive explicitly stipulates that the industrial application of a sequence or a partial sequence of a human gene must be disclosed in the patent application (Article 5 (3) Directive; Rule 29 (3) EPC IRs). The recitals and the parliamentary history indicate that the word 'industrial applicability' should be read as 'function', amounting to the obligation to indicate the function of a (partial sequence of a) gene. ${ }^{137}$ Furthermore, recent EPO case law emphasized that a "practical" application of the invention has to be disclosed. A typical case is the patent related to the production of the protein Tyrosine Phosphatase PTP20. ${ }^{138}$ The Board underlined that merely because a substance - in casu a polypeptide - can be produced in some ways does not necessarily mean that the industrial applicability requirement is fulfilled, unless there is also some profitable use for which the substance can be employed. ${ }^{139}$ Biotechnological inventions are quite often concerned with substances found in nature (e.g. a protein, a DNA sequence, etc.). In cases

naltrexone was considered essentially biological in nature and therefore the administration of the same could not be regarded as susceptible to industrial application. The Board took the view that the invention in case complied with the requirements of Article $57 \mathrm{EPC}$, as it was beyond doubt that the invention can be used by enterprises whose object is to beautify the human or animal body. Such enterprises in the cosmetic field - such as cosmetic salons and beauty parlours - are part of industry in the sense of Article $57 \mathrm{EPC}$, since the notion of concept 'industry' implies that an activity is carried out continuously, independently and for financial gain.

${ }^{134}$ Burk \& Lemley, 2009, 110-111.

${ }^{135}$ Revised Interim Uitlity Guidelines Training Materials, see http://www.uspto.gov/web/menu/utility.pdf, '). "Specific" means, for example, that a claim to a polynucleotide whose use is disclosed simply as a "gene probe" or "chromosome marker" would not be considered to be specific in the absence of a disclosure of a specific DNA target. "Substantial" refers to a utility that defines a 'real world' use. Utilities that require or constitute carrying out further research to identify or reasonably confirm a 'real world' context of use are not substantial utilities. "Credible" means whether the assertion of utility is believable to a person of ordinary skill in the art based on the totality of evidence and reasoning provided.

${ }^{136}$ In re Fisher, 421 F.3d 1365 (Fed. Cir. 2005). Check with Chisum on Patents

${ }^{137}$ Particularly relevant are Recitals 22, 23 and 24 of the EU Biotechnology Directive, which run as follows: "(22) Whereas the discussion on the patentability of sequences or partial sequences of genes is controversial; whereas, according to this Directive, the granting of a patent for inventions which concern such sequences or partial sequences should be subject to the same criteria of patentability as in all other areas of technology: novelty, inventive step and industrial application; whereas the industrial application of a sequence or partial sequence must be disclosed in the patent application as filed; (23) Whereas a mere DNA sequence without indication of a function does not contain any technical information and is therefore not a patentable invention; (24) Whereas, in order to comply with the industrial application criterion it is necessary in cases where a sequence or partial sequence of a gene is used to produce a protein or part of a protein, to specify which protein or part of a protein is produced or what function it performs" (My Italics). Also see EPO Guidelines - Part C IV.5.4 (2010).

${ }^{138}$ European patent application with publication no. 914.452 concerning novel PTP20, PCP-2, BDP1, CLK and SIRP proteins and related products and methods.

${ }^{139}$ EPO Technical Board of Appeal (T 0870/04), 11 May 2005 (Point 4 of the Reasons). 
where the structure and function of the substance is elucidated and means are provided for extracting it or producing it in large amounts, industrial applicability exists in relation to the possibility to exploit the information and technical means disclosed in order to manufacture the substance and use it for some function related to its natural one or for some other previously unknown (now disclosed) function or as a starting material for making useful analogs or derivatives with some improved features. If a function is well known to be essential for human health, then the identification of the substance having this function will immediately suggest a practical application in the case of a disease or condition caused by a deficiency, as was the case, for example, for insulin, human growth hormone or erythropoietin. In such cases, an adequate description will ensure in accordance with the requirements of Article $57 \mathrm{EPC}$ that the invention can be made or used in industry. ${ }^{140}$ In cases where a substance, naturally occurring in the human body, is identified, and possibly also structurally characterized and made available through some method, but either its function is not known or it is complex and incompletely understood, and no disease or condition has yet been identified as being attributable to an excess or deficiency of the substance, and no other practical use is suggested for the substance, then industrial applicability cannot be acknowledged. There must be a borderline between what can be accepted, and what can only be categorized as an interesting research result which per se does not yet allow a practical industrial application to be identified. Even though research results may be a scientific achievement of considerable merit, they are not necessarily an invention which can be applied industrially. ${ }^{141}$ A vague and speculative indication of possible objectives that might or might not be achievable by carrying out further research with the tool as described is not sufficient for fulfillment of the requirement of industrial applicability. The purpose of granting a patent is not to reserve an unexplored field of research for an applicant. ${ }^{142}$

In one of the very first national court decisions on industrial applicability for biotechnological inventions, the UK High Court of Justice Court of Appeal appeals court has invalidated a patent for lack of industrial application, ${ }^{143}$ despite a ruling of the EPO Board that the same patent was valid. ${ }^{144}$ The case demonstrates the danger of allowing parties to patent "too far upstream". Justice Jacob contended that, however clever and inventive discovering a gene sequence may have been, one cannot have a patent for it or for the protein for which it encodes if the patent does not disclose how it can be used. ${ }^{145}$ More in particular, it is difficult to see why the mere fact of the T-cell activity of Neutrokine- $\alpha$ may represent a valid basis for a possible industrial application". ${ }^{146}$

Policy lever

\footnotetext{
${ }^{140}$ Ibidem, Point 5 of the Reasons.

${ }^{141}$ Ibidem, Point 6 of the Reasons.

${ }^{142}$ Ibidem, Point 21 of the Reasons.

${ }^{143}$ High Court of Justice - Court of Appeal (on Appeal from the Chancery Division), Before the Rt Hon Justice Jacob (Elli Lilly v. Human Genome Sciences), 9 February 2010.

${ }^{144}$ EPO Technical Board of Appeal (T 18/09), 21 October 2009, relating to European patent 939.804, concerning a Neutrokine- $\alpha$ polypeptide, awarded to Ely Lilly. Claim 1 as granted reads as follows: "1. A nucleic acid molecule comprising a polynucleotide sequence encoding a Neutrokine- $\alpha$ polypeptide wherein said polynucleotide sequence is selected from the group consisting of: (a) a polynucleotide sequence encoding the full length Neutrokine- $\alpha$ polypeptide having the amino sequence or residues 1 to 285 of SEQ ID NO:2; (b) a polynucleotide sequence encoding the extracellular domain of the Neutrokine- $\alpha$ polypeptide having he amino acid sequence of residues 73 tot 285 of SEQ ID NO:2; (c) ...; (d) ...; (e) ... (f) ...”.

${ }^{145}$ High Court of Justice - Court of Appeal (on Appeal from the Chancery Division), Before the Rt Hon Justice Jacob (Elli Lilly v. Human Genome Sciences), 9 February 2010. Previous footnote. (Point 57 of the Reasons).

${ }^{146}$ High Court of Justice - Court of Appeal (on Appeal from the Chancery Division), Before the Rt Hon Justice Jacob (Elli Lilly v. Human Genome Sciences), 9 February 2010. Previous footnote. (Point 155 of the Reasons).
} 
In European patent law, the industrial applicability requirement constitutes both a macro and a micro policy lever in biotechnology. First and foremost, the industrial applicability requirement makes for a statutory macro policy lever. By expressly demanding the 'function' of (partial sequences of) genes, European patent law establishes a specific standard for inventions in the biotechnological field. Second, the industrial applicability requirement also constitutes a judicial micro policy lever particularly relevant in the context of biotechnology. By repeatedly underlining that the notion of 'industry' implies that an activity is carried out continuously, independently and for financial, commercial gain, the European industrial applicability requirement, being nominally neutral vis a vis specific industry sectors, favors technologies and/or industries which develop inventions which are more downstream and closer to the market. Applying the prevailing 'industry' interpretation rigorously within the biotechnology industry, might ultimately lead to a patent scenario where precedence is given to end products with a definite commercial value over research tools. Such an approach definitely has positive effects, as products and processes which are useful for research are not appropriable by patents and will, in principle, be available for use to all. However, such an approach might also have negative effects, as research tools, in the absence of patent protection, are denied the patent incentive, possibly resulting in lesser innovation.

\subsubsection{Skilled person}

\section{The role of the skilled person}

In US patent law, the "person having ordinary skill in the art" (PHOSITA) plays a pivotal role in deciding on a series of factual questions, which are measured from his/her perspective. First and foremost, the PHOSITA plays an important role in the assessment of obviousness: "A patent may not be obtained [...] if the differences between the subject matter sought to be patented and the prior art are such that the subject matter as a whole would have been obvious at the time the invention was made to a person having ordinary skill in the art to which said subject matter pertains" (35 USC 103). In other words, an invention may not have been obvious to a person with ordinary skill in the art to which the subject matter of the invention pertains at the time of the invention and in the light of the teachings of the prior art. ${ }^{147}$ The PHOSITA also comes to the fore to assess the adequacy of the patent disclosure: "The specification shall contain a written description of the invention, and of the manner and process of making and using it, in such full, clear, concise, and exact terms as to enable any person skilled in the art to which it pertains, or with which it is most nearly connected, to make and use the same, and shall set forth the best mode contemplated by the inventor of carrying out his invention" (35 USC 112). Last but not least, the PHOSITA is also central in defining the patent scope. The patent claims are being assessed with regard to the knowledge of a person having skill in the art. ${ }^{148}$

In European patent law the "person skilled in the art" (PSITA) also plays a key role. First, the PSITA is of importance in the framework of the inventive step assessment: "An invention shall be considered as involving an inventive step if, having regard to the state of the art, it is not obvious to a person skilled in the art" (Article 56 EPC). The PSITA also plays a vital role in the context of the patent disclosure: "The European patent application shall disclose the invention in a manner sufficiently clear and complete for it to be carried out by a person skilled in the art" (Article 83 EPC). Sanctions for non adequate disclosure are fierce, ranging

${ }^{147}$ Check with Chisum on Patents, $§ 5.01$

${ }^{148}$ Citation - Chisum on Patents? 
from opposition ${ }^{149}$ to revocation. ${ }^{150}$ Last but not least, the PSITA also shows up in the framework of claim interpretation and patent scope. The EPC is not very explicit about the role of the PSITA in this regard, ${ }^{151}$ but all the more so are the national courts of the member states, where quite often reference is made to how the PSITA would understand the terms in patent claims. Exemplary in this regard is the enunciation of the honorable Lord Hoffman who stated that "The question is always what the person skilled in the art would have understood the patentee to be using the language of the claim to mean". ${ }^{152}$

\section{The profile of the skilled person}

\section{In general}

Having elucidated the role of the skilled person, who exactly is he/she? In EPO case law the profile of the skilled person has been extensively debated. For the purpose of the inventive step assessment, the PSITA should be presumed to be an ordinary practitioner aware of what was common general knowledge in the art at the relevant date, not supposed to possess any inventive capability. Nevertheless the PSITA is expected to look for suggestions in neighboring fields if the same or similar problems arise in these fields. If the problem prompts the PSITA to seek its solution in another technical field, the specialist in that field is the person qualified to solve the problem and the assessment of whether the solution involves an inventive step will have to be based on that specialist's knowledge and ability. An interesting example relates to the assessment of inventive step of a cleaning apparatus for an endless conveyor belt, where the solution to the problem consists in discovering a rod-shaped elastic element which is less prone to breakage, reference to the knowledge and capabilities of a materials specialist, rather than a conveying equipment specialist, will have to be made. ${ }^{153}$ In

\footnotetext{
${ }^{149}$ See Article 100 (b) EPC, stipulating that "Opposition may only be filed on the grounds that the European patent does not disclose the invention in a manner sufficiently clear and complete for it to be carried out by a person skilled in the art".

${ }^{150}$ See Article 138 (1) (b) EPC, setting forth that "A European patent may be revoked with effect for a Contracting State only on the grounds that: the European patent does not disclose the invention in a manner sufficiently clear and complete for it to be carried out by a person skilled in the art".

${ }^{151}$ Article 69 (1) EPC stipulates that "The extent of the protection conferred by a European patent or a European patent application shall be determined by the claims". Article 1 Protocol on the Interpretation of Article 69 EPC of 5 October 1973 as revised by the Act revising the EPC of 29 November 2000 adds that "Article 69 should not be interpreted as meaning that the extent of the protection conferred by a European patent is to be understood as that defined by the strict, literal meaning of the wording used in the claims, the description and drawings being employed only for the purpose of resolving an ambiguity found in the claims. Nor should it be taken to mean that the claims serve only as a guideline and that the actual protection conferred may extend to what, from a consideration of the description and drawings by a person skilled in the art, the patent proprietor has contemplated. On the contrary, it is to be interpreted as defining a position between these extremes which combines a fair protection for the patent proprietor with a reasonable degree of legal certainty for third parties.

${ }^{152}$ House of Lords (Kirin-Amgen Inc. v. Hoechst Marion Roussel Ltd), 21 October 2004, [2004] UKHL 46; [2005] R.P.C. 9.

${ }^{153}$ EPO Technical Board of Appeal (T 32/81), 5 March 1982, OJ EPO 1982, 225, relating to European patent application with publication no 4.809 concerning a cleaning apparatus for endless conveyor belt. The application was refused by decision of the Examining Division arguing that by reference to the general knowledge of any technically skilled person the invention was certainly new but did not involve an inventive step. The Board argued that the problem to be solved consisted in discovering a rod-shaped elastic element which is less prone to breakage, which problem undeniably confronts the conveying equipment specialist; however, it prompts him at the same time to seek its solution in the field of material science. Consequently, the skilled person qualified to solve the problem cannot be a conveying equipment specialist, but has to be a materials specialist alone. Therefore, the assessment of whether the problem's solution involves an inventive step must be made by reference to the knowledge and ability of a materials specialist, not a conveying equipment specialist (Point 4.2. of the Reasons). Also see EPO, Case Law of the Boards of Appeal, 2006, p. 135 - under 7.1.1.
} 
advanced technical fields the PSITA could be a team of two or more experts from the relevant technical branches. For example, for the assessment of an invention relating to an iongenerating plasma apparatus, the semiconductor-expert would team up with a plasma specialist. ${ }^{154}$ Or in the field of advanced laser technology, the PSITA would be seen as a production team of three experts, one in physics, one in electronics and one in chemistry. ${ }^{155}$ For the purpose of disclosure, the PSITA should make use of his common general knowledge. ${ }^{156}$ Textbooks and general technical literature form part of the common general knowledge ${ }^{157}$, whereas information which can only be obtained after a comprehensive search is not to be regarded as part of the common general knowledge. ${ }^{158}$ The PSITA should not employ any inventive effort over and above his ordinary skills. ${ }^{159}$ In new fields of research, where relevant technical knowledge is not yet available from textbooks, patent specifications

154 EPO Technical Board of Appeal (T 424/90), 11 December 1991, relating to European patent 84.970 concerning a magnetically enhanced plasma process and apparatus. The Board held that the claimed apparatus is no doubt intended to be used in the reactive ion etching but did not accept that the competent skilled person is merely a semiconductor specialist. The Board considered that in real life, a semiconductor specialist would consult a plasma specialist, if his problem concerns providing a technical improvement of an ion generating plasma apparatus and the semiconductor specialist would be expected to form a team with the plasma specialist. In the Board's view, it is appropriate to follow Decision T 32/81, and to base the assessment of whether the claimed solution involves an inventive step on the knowledge and abilities of the specialist in that technical field in which the objective problem prompts the person skilled in the art to seek its solution (Point 1.3. of the Reasons).

155 EPO Technical Board of Appeal (T 222/86), 22 September 1987, relating to European patent 8.513 concerning a method and system to depict a picture of an object, such invention belonging to the technical field of laser engraving. In the opinion of the Board, laser engraving represents an advanced technology, where it is appropriate to identify the skilled person to be a production team of the following three experts: a physicist, who is competent for the laser, an expert in electronics, who is competent for the scanning and modulation, and a chemist, who is competent for the photosensitive layer of the recording carrier. The Board further underlines that the person qualified to solve a problem is regarded to be the specialist of the particular technical field, in which the particular problem prompts a skilled person to seek its solution, referring to Decision T 32/81 (Point 4.2 of the Reasons).

156 EPO Technical Board of Appeal (T 206/83), 26 March 1986, OJ EPO, 1987, 5 relating to European patent 1.473 concerning herbicidal halogenomethyl-pyridyloxy-phenoxy-alkanecarboxylic acids and derivatives, and processes of controlling unwanted plants therewith. The Board stated that the person skilled in the art is expected to have common general knowledge at his immediate disposal and that it would be unfair if more were to be expected of him, i.e. an awareness of the whole state of the art (Point 5 of the Reasons).

${ }^{157}$ EPO Technical Board of Appeal (T 206/83), 26 March 1986, OJ EPO, 1987, 5 (previous footnote). The Board underlined that it is normally accepted that common general knowledge is represented by basic handbooks and textbooks on the subject in question. The skilled person could well be expected to consult these to obtain clear advice as to what to do in the circumstances, since the skills of such persons not only includes knowledge about particular basic prior art but also knowledge as to where to find such information. Such books may indeed refer him to articles describing specifically how to act or at least giving a fairly generally applicable method for the purpose, which can be used without any doubt (Point 5 of the Reasons). Also see EPO Technical Board of Appeal (T 171/84), 24 October 1985, relating to European patent 3.870 concerning polymer resin emulsions. The Board argued that the document referred to by the appellant as closest prior art was neither cited in the patent specification in support of the disclosure, nor had it become part of common general knowledge, e.g. through appreciation in a standard textbook.

${ }^{158}$ EPO Technical Board of Appeal (T 206/83), 26 March 1986, OJ EPO, 1987, 5 (previous footnote). In casu, the Board was of the opinion that the indexes of Chemical Abstracts cover virtually the whole state of the art, and represent therefore much more than what is assumed to be the common general knowledge. Reliance on the contents of Chemical Abstracts to rectify insufficiency might be tantamount to leave the skilled reader to carry out a search in the whole state of the art, which would be an unacceptable burden (Point 6 of the Reasons).

${ }^{159}$ EPO Technical Board of Appeal (T 10/86), 1 September 1988, relating to European patent 49.816 concerning

a process for obtaining energy from the mass-energy equivalence at the formation of protons and neutrons. 
and scientific publications may be considered to form part of the common general knowledge. ${ }^{160}$

Finally, for the purpose of claim interpretation, the PSITA is expected to rule out interpretations which are illogical or which do not make technical sense. He/she should try, with synthetical propensity, i.e. building up rather than tearing down, to arrive at an interpretation of the claim which is technically sensible and takes into account the whole disclosure of the patent (Art. $69 \mathrm{EPC}$ ) and he should construe the patent by a mind willing to understand, not a mind desirous of misunderstanding. ${ }^{161}$

\section{In biotechnology}

EPO jurisprudence has given special consideration to the PSITA in the field of biotechnology. ${ }^{162}$ The Technical Boards of Appeal have confirmed prevailing case law on the notion of 'common general knowledge' and set forth that common general knowledge generally can be considered the information contained in basic handbooks, monographs and textbooks on the subject in question. ${ }^{163}$ Furthermore, the Boards have argued that the PSITA in biotechnology is considered to be conservative. He would never go against an established prejudice, nor try to enter unpredictable areas, nor take incalculable risks. The PSITA would only perform a transfer of technology from a neighboring field to his specific field of interest, if this transfer involved routine experimental work comprising only routine trials. ${ }^{164}$ The

${ }^{160}$ EPO Technical Board of Appeal (T 51/87), 8 December 1988, OJ EPO 1991, 177, relating to European patent 2.615 concerning 13-Halo and 13-deoxy derivatives of modified milbemycin compounds and their preparation. By contrast to previous decisions (see T 206/83, "Herbicides",previous footnote and T 171/84, "Redox Catalyst", OJ EPO 1986, 95), where the Board held that patent specifications were not normally part of the common general knowledge of the natural skilled addressee, the Board argued in the present case that the starting compounds at stake (highly elaborated microbial metabolites) opened a brand new field of research, so that any technical knowledge acquired in this field at the beginning, through basic pioneering work had not yet been distilled into the form of textbooks. In prior decisions (see T 206/83, previous footnote) the situation was quite different, as the PSITA was a person working in the field of classical herbicide chemistry, which was not a new developing field like that of the chemistry of C-076 compounds here. The PSITA, therefore, could not be presumed to possess the same common general knowledge in both cases.

${ }^{161}$ EPO Technical Board of Appeal (T 190/99) 6 March 2001, relating to European patent 448.265 concerning a woven slide fastener stringer (Point 2.4 of the Reasons). Also see EPO, Case Law of the Boards of Appeal, 2006, p. 205.

${ }^{162}$ An interesting measure for comparison may be found in E. Richard Gold and Karen Lynne Durell, Innovating the Skilled Reader: Tailoring Patent Law to New Technologies (19(1) Intellectual Property Journal, 189-226, 2005) where the skilled reader has been analysed in Canadian case law in an attempt to prove that 'one size does not fit all'.

${ }^{163}$ EPO Technical Board of Appeal (T 890/02), 14 October 2004, OJ EPO, 497, relating to European patent application No. 96920888.3 (with international publication No. WO 96/38567) concerning DNA sequences of a gene of hydroxy-phenyl pyruvate dioxygenase and production of plants containing a gene of hydroxy-phenyl pyruvate dioxygenase, which plants are tolerant to certain herbicides, submitted by Bayer CropScience. The Board held that whilst not being stricto sensu encyclopaedias or handbooks, the ENZYME and the EMBL databases nonetheless answer to the definition of, respectively, an encyclopaedia or a handbook. Furthermore, they fulfil the three criteria set out in the case law when defining the common general knowledge, namely (a) they are known by the skilled person to be an appropriate source for obtaining the desired information, (b) looking for this information requires no undue effort, since no search strategy is needed but only the EC number or the enzyme name (in the present case the enzyme name is known from document D10 itself), and (c) the information retrieved (for example, the nucleotide sequence) does not need any further research work, i.e. it is unambiguous and straightforward. For these reasons, in the Board's judgment, the information in these databases ENZYME and EMBL meets the definition of common general knowledge given in the case law (Point 9 of the Reasons). Also see EPO Guidelines (2010) Part C - Chapter II - 4.1 and the cases cited there.

164 EPO Technical Board of Appeal (T 455/91), 20 June 1994, OJ EPO 1995, 684 relating to European patent 60.057 concerning the expression of polypeptides in yeast. In the Board's view, the conservative attitude must not be seen in the sense of being reluctant or opposed to modify or adjust a known product or process, but 
PSITA would not engage in creative thinking: it is not the Nobel Prize laureate's level of skill which determines the PSITA and hence what must be considered as falling within common general knowledge of the time. ${ }^{165}$

An illustrative example of the profile of the PSITA in biotechnology is the inventive step assessment applied for the identification, characterization and production of human immune interferon. In this case the Board had to consider the knowledge and capabilities of the PSITA in the field of genetic engineering around October $1981 .{ }^{166}$ By this time, a considerably greater number of genes had been made the subject of cloning and expressing methods, and skills and experience in this technical field were developing rapidly. The PSITA had to be assumed to lack the inventive imagination to solve problems for which routine methods of solution did not already exist. The knowledge of the PSITA had to be considered as that of a team of appropriate specialists who knew all the difficulties still to be expected when considering the cloning of a new gene. Similarly, in the case of the production of erythropoietin, it was agreed that the PSITA could be treated as "a team of three composed of one $\mathrm{PhD}$ researcher with several years experience in the aspect of gene technology or biochemistry under consideration, assisted by two laboratory technicians fully acquainted with the known techniques relevant to that aspect". ${ }^{167}$

rather in the sense of being cautious. For example, the skilled person in question would neither go against an established prejudice nor try to enter into "sacrosanct" or unpredictable areas nor take incalculable risks. However, within the normal design procedures, the said expert would readily seek appropriate, manifest changes, modifications or adjustments which involve little trouble or work and no risks or only calculable risks, especially for the sake of obtaining a more handy or convenient product or of simplifying a procedure. In particular, the skilled person working in one field (eg expression in yeast) would regard a means conveniently adopted in a neighboring field (eg the bacterial art) as being readily usable also in that field, if this transfer of technical knowledge involves nothing out of the ordinary" (Point 5.1.3.3 of the Reasons).

${ }^{165}$ EPO Technical Board of Appeal (T 60/89), 31 August 1990, OJ EPO 1992, 268 relating to European patent 6.694 (see previous footnote). In the opinion of the Board the skilled person in the field of genetic engineering in 1978 [the year in which the priority application had been submitted] is not to be defined as a Nobel Prize laureate, even if a number of scientists working in this field at that time were actually awarded the Nobel Prize. Rather, it is understood that the skilled person was to be seen as a graduate scientist or a team of scientists of that skill, working in laboratories which developed from molecular genetics to genetic engineering techniques, at that time (Point 2.2.4 of the Reasons). Also see EPO Technical Board of Appeal (T 0500/91), 21 October 1992, relating to European patent 32.134, concerning DNA sequences, recombinant DNA molecules and processes for producing human interferon-alpha like polypeptides awarded to Biogen on 15 August 1984: "It is true that at the priority date of the disputed patent, only a limited number of persons were skilled in recombinant DNA-technology and that probably all of them were advanced senior scientists with skills above the average level in the broader art of biochemistry. [...] the notional person skilled in the art of genetic engineering would not be defined as a Nobel Prize laureate, but rather a graduate scientist or a team of scientists of that level of skill, working in laboratories which were developing genetic engineering techniques, in contrast to developing the science of molecular genetics, at the time in question (in that particular case around 1978)" (Point 2.2 of the Reasons). In other words, in accordance with the established jurisprudence of the Boards of Appeal, the notional skilled person who may be represented by a team of appropriate specialists (T 141/87 of 29 September 1989, not published in the OJ EPO and T 60/89), the PSITA is oriented towards practicalities, and the development of the art normally expected by him does not include solving technical problems by performing scientific research in areas not yet explored" (Point 2.2 of the Reasons).

${ }^{166}$ EPO Technical Board of Appeal (T 223/92), 20 July 1993, relating to European patent 77.670 concerning human immune (gamma) interferon (IFN- gamma) awarded to Genentech on 28 June 1989. Appeal against the Decision of the EPO Opposition Division from 13 January 1992 rejecting the opposition filed against EP 6.694. This is more than one year later than was the case in T 500/91 (see previous footnote).

${ }^{167}$ EPO Technical Board of Appeal (T 412/93), 21 November 1994, relating to European patent 148.605 concerning the production of recombinant erythropoietin and awarded to Kirin Amgen on 25 July 1990. The parties agreed that for this case the skilled person should be treated as a team of three composed of one $\mathrm{PhD}$ researcher with several years experience in the aspect of gene technology or biochemistry under consideration, assisted by two laboratory technicians fully acquainted with the known techniques relevant to that aspect. [...] This definition of the skilled person coincides with the view of the Board, and references in this decision to "skilled person" are to be interpreted as meaning this team. In decision T 223/92 (loc. cit.) where the priority 
EPO jurisprudence also clarified that the same level of skill has to be applied when, for the same invention, the question of inventive step (Article 56 EPC) and sufficient disclosure (Article 83 EPC) have to be considered. ${ }^{168}$ Although the same level of skill is applied for both questions, the two starting points differ: for inventive step purposes, the skilled man knows only the prior art, whereas for sufficiency of disclosure, he knows the prior art and the disclosed invention. ${ }^{169}$

Policy lever

In Europe, the skilled person was formally called into life by the legislature and was mainly fleshed out by EPO case law: the definition of the role of the PSITA is mainly statutory, whereas the description of the exact profile of the PSITA is mainly judicial. Comparing the profile of the PSITA in general and in the domain of biotechnology, does not seem to reveal different standards. Rather than variations between industry sectors, other differences come to the fore. First, a distinction between 'old' and 'new' fields of research can be disentangled. In 'old', conventional technical areas the standard of the PSITA seems to be lower than the level of the PSITA in 'new' technological fields. In conventional fields common general knowledge is formed by textbooks, whereas in new fields, common general knowledge encompasses patent specifications and scientific publications as well. Furthermore, a distinction between 'low' and 'advanced' technologies can be observed. In 'low' key technologies, the PSITA measuring certain factual questions can be a single skilled person. In advanced and more complex fields of research, the PSITA is not necessarily one skilled person, but can be held to be a team of skilled persons. Since the biotechnological field is both 'new' and pretty 'advanced', the level of the PSITA can differ from other sectors, leading to the conclusion that the PSITA can, indirectly, be seen as a judicial micro policy lever. So, we tend to disagree with Burk and Lemley who claim that the use of the PHOSITA is a judicial macro policy lever because it explicitly creates different standards for different technologies and different industries, thus creating the most fundamental policy lever, because it makes so much turn on the knowledge of scientists in any given field. ${ }^{170}$

\subsubsection{Enabling disclosure}

In general

claimed was for much the same time, 1983, as in this case, the Board considering that case defined the "skilled person" as a highly skilled technician (Point 5.5 of the Reasons), which in real terms would mean a PhD. researcher for the knowledge. The notional skilled person in terms of patent law can then be treated as comprising this researcher and two laboratory assistants having the necessary manual dexterity and lack of fatigue (Point 4 of the Reasons).

${ }^{168}$ EPO Technical Board of Appeal (T 60/89), 31 August 1990, OJ EPO 1992, 268. The case relates to European patent 6.694 awarded to Harvard College concerning a method of making a selected protein by inserting DNA, and invented by Walter Gilbert. The Board adopts the view that the same level of skill has to be applied when, for the same invention, the two questions of sufficient disclosure and inventive step have to be considered (Point 3.2.5 of the Reasons).

169 EPO Technical Board of Appeal (T 694/92), 8 May 1996, OJ EPO 1997, 408, relating to European patent 122.791 concerning plant gene expression and awarded to Mycogen Plant Science. Parting from previous case law (see T 60/89, previous footnote) the Board underlined that "whereas for the purpose of evaluating inventive step the skilled person has knowledge of the prior art only, for the purpose of evaluating sufficiency of disclosure (and, hence, support) he or she has knowledge of the prior art and of the invention as disclosed".

${ }^{170}$ Burk \& Lemley, The Patent Crisis, 2009, 116. 
In the US, the UPA prescribes that the specification shall contain a written description of the invention (written description requirement) in such full, clear, concise, and exact terms as to enable any person skilled in the art to make and use the same (enablement requirement), and shall set forth the best mode contemplated by the inventor of carrying out his invention (best mode requirement) (35 USC 112). The modern purpose of the written description requirement is to provide evidence that the patent applicant has conceptual possession of the invention. ${ }^{171}$

In Europe, the EPC equally prescribes that a European patent application shall disclose the invention in a manner sufficiently clear and complete (written description requirement) for it to be carried out by a person skilled in the art (enablement requirement), but the EPC does not require best mode (Article $83 \mathrm{EPC}$ ). EPO case law clarifies that sufficiency of disclosure must be assessed on the basis of the application as a whole, including the description and claims ${ }^{172}$, and not of the claims alone. EPO jurisprudence has further added, that whether the invention is indeed disclosed sufficiently in accordance with article $83 \mathrm{EPC}$, will be assessed through the eyes of PSITA's common general knowledge at the relevant date. ${ }^{173}$ EPO case law also underlined that the disclosure should be reproducible without undue burden, apart from unexplored fields, where a reasonable amount of trial and error is permissible. ${ }^{174}$ Last but not least, it is required that an invention shall describe in detail at least one way of carrying out the invention claimed, using examples where appropriate (Rule 42 (1) (e) EPC IRs).

\section{In biotechnology}

${ }^{171}$ Burk \& Lemley, The Patent Crisis, 2009, 118. Check with Chisum on Patents

${ }^{172}$ See EPO Technical Board of Appeal (T 14/83), 7 June 1983, OJ EPO, 1984, 105, relating to European patent application with publication no 4.795 , concerning a method for producing a vinyl chloride resin. The Board took the view that the question whether an invention has been disclosed sufficiently clear and completely is not to be decided solely on the basis of the content of the claims. If a chemical invention involves the task of manufacturing a product with certain measurable properties (e.g. gel content or degree of polymerisation of a copolymer), and this task is performed by means of a process involving several variables, then the means of its performance are to be regarded as sufficiently disclosed within the meaning of Article 83 EPC if, encountering occasional lack of success notwithstanding strict adherence to the prescribed limits of those variables, clear information, contained in the description, regarding the effects of individual variables on the properties of the product enables the person skilled in the art to bring about the desired properties quickly and reliably in such an event (Headnote 1).

${ }^{173}$ See EPO Technical Board of Appeal (T 322/93), 2 April 1997 relating to European patent application with publication no 250.766 concerning microemulsions containing perfluoropolyethers. The Board confirmed that literally fulfilling the statutory requirements does not automatically mean that the application as filed contains sufficient information to allow a person skilled in the art, using his common general knowledge, to carry out the invention without undue burden within substantially the whole area that is claimed. That has to be decided by appraising the information contained in the examples as well as the other parts of the description in the light of the skilled person's common general knowledge at the relevant date (Point 3.1. of the Reasons).

${ }^{174}$ EPO Technical Board of Appeal (T 226/85), 17 March 1987, OJ EPO1988, 336 relating to European patent 9.942 concerning a pourable scouring cleanser composition. The Board stated that even though a reasonable amount of trial and error is permissible when it comes to the sufficiency of disclosure in an unexplored field or as it is in this case - where there are many technical difficulties, there must then be available adequate instructions in the specification or on the basis of common general knowledge which would lead the skilled person necessarily and directly towards success through the evaluation of initial failures or through an acceptable statistical expectation rate in case of random experiments (following decision T 14/83). In the present appeal the sensitivity or inherent instability of the composition, or other unexplained circumstances are such that the skilled person can only reproduce the invention in a number of instances with some luck, if at all, in view of the unknown character of reasons which cause failure. For this reason, the patent is invalid in its entirety for not complying with the requirements of Article 83 EPC (Point 8 of the Reasons). Also see EPO, Case Law of the Boards of Appeal, 2006. 
In the US, the written description requirement has been enforced quite stringently in biotechnology. In various cases where human DNA sequences were claimed, US courts repeatedly underlined that the written description requirement is not adequately met when the actual DNA sequence is not fully disclosed and that a full description of the DNA itself is required. ${ }^{175}$ Recently, Guidelines have formally implemented this viewpoint.

In Europe, the written description requirement has also been applied quite rigorously. According to EPO policy and case law, DNA sequences were to be fully represented. Rule 30 EPC IRs now formally requires that if nucleotide or amino acid sequences are disclosed in the European patent application, the description shall contain a sequence listing conforming to the rules laid down by the President of the EPO for the standardized representation of nucleotide and amino acid sequences. ${ }^{176} 177$

EPO case law on enablement has been focusing a lot on the one-way-rule. An illustrative example is the invention relating to the expression of preprochymosin. ${ }^{178}$ The patent specification provided a technically detailed example for the expression of preprochymosin and its maturation forms in E.coli. Although the parties agreed that sufficient information was given to reproduce the invention in E.coli, it was debated whether sufficiency of disclosure was achieved in relation with a process for expression in micro-organisms in general. ${ }^{179}$ The patentee claimed that expression in micro-organisms was definitely intended and that the references to expression sufficed to establish enablement, as the state of the art provided examples of foreign gene expression in eucaryots (such as yeasts) and procaryots; chymosin being an eucaryotic gene should be more likely to express in eucaryots than in E.coli. ${ }^{180}$ The Board believed that one way to carry out the invention was clearly indicated, that there existed no serious doubts that the invention could eventually be carried out with other microorganisms than E.coli ${ }^{181}$, and decided that the invention was sufficiently disclosed.

Another interesting case is the patent related to the production of recombinant interferon. The invention provided a route, through recombinant DNA technology, to certain types of interferons but in a manner that would not provide identical results each time when repeated. It was the view of the Board that variations in the construction within a class of genetic precursors, such as recombinant DNA molecules claimed by a combination of structural limitations and functional tests, are immaterial to the sufficiency of the disclosure provided the skilled person could reliably obtain some members of the class without necessarily knowing in advance which member would thereby be made available. So, an invention may also be sufficiently disclosed where results are not exactly repeatable. ${ }^{182}$

\footnotetext{
${ }^{175}$ Fiers v. Revel, 984 F.2d 1164 (Fed. Cir. 1993); Regents of the University of California v. Eli Lilly, 119 F.3d 1559 (Fed. Cir. 1997).

${ }^{176}$ Rule 30 EPC IRs has been introduced as a result from the decision of the President of the EPO and the Notice from the EPO, Special edition No. 3, OJ EPO 2007, C.1. and C.2.

${ }^{177}$ If such a list is not provided within a period of two months, the application shall be refused. See Rule 30 (3) EPC IRs: "Where the applicant has not filed a sequence listing complying with the requirements under paragraph 1 at the date of filing, the European Patent Office shall invite the applicant to furnish such a sequence listing and pay the late furnishing fee. If the applicant does not furnish the required sequence listing and pay the required late furnishing fee within a period of two months after such an invitation, the application shall be refused".

${ }^{178}$ European patent application with publication no 77.109, concerning DNA molecules comprising the genes for preprochymosin and its maturation forms, and microorganisms transformed thereby.

${ }^{179}$ EPO Technical Board of Appeal (T 386/94), 11 January 1996, OJ EPO 1996, 658 (Point 8 of the Reasons).

${ }^{180}$ Ibidem (Point 9 of the Reasons).

${ }^{181}$ Ibidem (Point 14 of the Reasons).

${ }^{182}$ EPO Technical Board of Appeal (T 301/87), 16 February 1989, OJ EPO 1990, 335. Also see EPO Technical Board of Appeal (T 636/97), 26 March 1998, relating to European patent 148.605 concerning the production of erythropoietin and awarded to Kirin Amgen: "For the board it is a fundamental principle of patent law that a
} 
Yet another prominent case, is the invention relating to a method for producing transgenic animals, resulting in the famous Harvard-oncomouse patent. ${ }^{183}$ The claimed invention was defined by the incorporation of an activated oncogene sequence into the genome of nonhuman mammalian animals. ${ }^{184}$ The Examining Division took the view that the claimed invention referred to all non-human mammalian animals, whereas the invention described in the examples had been performed only on mice. Not convinced that a skilled person would be able to carry out successfully on all other kinds of non-human mammals the invention as performed on mice, the Examining Division refused the application, inter alia, on the ground that the claims were unrealistically broad. ${ }^{185}$ The Board argued, however, that the mere fact that a claim is broad is not in itself a ground for considering the application as not complying with the requirement for sufficient disclosure. Only if there are serious doubts, substantiated by verifiable facts, may an application be objected to for lack of sufficient disclosure. ${ }^{186}$

\section{Policy lever}

At first sight, it seems that the enabling disclosure standard is relatively high in biotechnology, especially in the area of DNA sequences. Initiated by EPO case law, the current enabling disclosure standard for DNA sequences is now formally embedded in the EPC. Thus the enabling disclosure requirement turned from a judicial into a statutory macro policy lever.

Burk and Lemley quite understandably expect that a more stringent written description requirement results in DNA patents with a narrower scope, in other words, that the effect of a stringent written description requirement is narrower scope. ${ }^{187}$ However, scrutinous analysis of a large set of human DNA claims proved that this is not always the case, and that quite some broad and unclear DNA patents have been awarded. ${ }^{188}$

\subsection{Patent scope}

Now the policy levers affecting patent acquisition have been screened, we now turn to policy levers dealing with patent scope. The policy levers affecting scope of protection and rights of the patentee are being treated separately. Indeed, European case law has introduced a clear

claim can validly cover broad subject matter, even though the description of the relevant patent does not enable every method of arriving at that subject matter to be carried out. Otherwise no dominant patent could exist, and each developer of a new method of arriving at that subject matter would be free of earlier patents. In many cases in the field of biotechnology, patent protection would then become illusory. This is not to say that some claims might not be too broad in scope and not be enabled over their whole scope for the purpose of Article 83 EPC but this was not considered to be the case in respect of Claim 1 by this Board in T 412/93 on the evidence before the board and this is res judicata" (Point 4.5 of the Reasons).

${ }^{183}$ European patent 169.672 (B1), granted 13 May 1992.

${ }^{184}$ See e.g. claim 19, claiming "A transgenic non-human mammalian animal whose germ cells and somatic cells contain an activated oncogene sequence as a result of chromosomal incorporation into the animal genome, or into the genome of an ancestor of said animal, said oncogene optionally being further defined according to any one of the claims 3 to 10 ”.

${ }^{185}$ EPO Techncial Board of Appeal (T 19/90), 3 October 1990, OJ EPO 1990, 476 (Point 3.2. of the Reasons). ${ }^{186}$ Ibidem (Point 3.3. of the Reasons).

187 "Application of the enablement requirement through the intermediary of the PHOSITA has the same narrowing effect. In certain industries, such as software, the enablement requirement is easily satisfied and therefore plays virtually no role in limiting the scope of claims. In other industries, such as biotechnology, the doctrine has been applied with much more vigor" (Burk \& Lemley, The Patent Crisis, 2009, 122).

${ }^{188}$ See Huys, I., Berthels, N., Matthijs, G. \& Van Overwalle, G., 'Legal Uncertainty in the Area of Genetic Diagnostic Testing', 27, Nature Biotechnology, October 2009, 903-909. For a discussion, see below, sections 2.2.2. and 2.2.3. 
distinction between the protection and the rights which are conferred by a patent. The protection conferred by a patent is determined by the terms of the claims (Article 69 (1) EPC), and in particular by the categories of such claims and their technical features. In this connection, Article 69 EPC and its Protocol are to be applied, both in proceedings before the EPO and in proceedings within the Contracting States, whenever it is necessary to determine the protection which is conferred. In contrast, the rights conferred on the proprietor of a European patent (Article 64 (1) EPC) are the legal rights which the law of a designated Contracting State may confer upon the proprietor, for example, as regards what acts of third parties constitute infringement of the patent, and as regards the remedies which are available in respect of any infringement. ${ }^{189}$

\subsubsection{Scope of product claims - absolute vs. limited scope}

\section{In general}

US patent law is conceived as a patent system providing absolute product protection. ${ }^{190}$ European patent law equally provides full product protection. EPO case law has pointedly expounded that the protection conferred by a product claim to a physical entity, such as a compound per se, confers absolute protection upon such physical entity, that is, "wherever it exists and whatever its context (and therefore for all uses of such physical entity, whether known or unknown)". ${ }^{191}$

\section{In biotechnology}

From the early ages of biotechnology onwards, the EPO took the view that the absolute product protection regime would equally apply to biotechnological inventions. This approach was laid down and further elaborated in the EU Biotechnology Directive which stipulates that the protection conferred by a patent on a product containing or consisting of genetic information shall extend "to all material, in which the product is incorporated and in which the genetic information is contained and performs its function" (Article 9 EU Biotechnology Directive). The wide approach put forward in the Directive caused a lot of controversy. The central question in this debate was whether a patent for a DNA sequence could encompass all possible future applications, or whether it should be restricted to the specific use described in the patent application. In other words, should DNA patents follow the regime of the classical, wide, absolute protection (absoluter Stoffschutz)? Or should a restricted purpose bound protection (zweckgebundener or funktionsgebundener Schutz) apply? Only recently, the European Commission emphasized that it does not intend to take a particular standpoint between classical and narrow scope of protection for DNA sequences. ${ }^{192}$ Based on an analysis of the Directive, the Commission concluded that a broad interpretation is acceptable

\footnotetext{
${ }^{189}$ EPO Enlarged Board of Appeal (G 02/88), 11 December 1989 (Mobil Oil III), OJ EPO, 1009, 93 (Point 3.3. of the Reasons).

${ }^{190}$ Check with Chisum on Patents

${ }^{191}$ EPO Enlarged Board of Appeal (G 02/88), 11 December 1989 (Mobil Oil III), OJ EPO, 1009, 93 (Point 5 of the Reasons).

${ }^{192}$ Commission of the European Communities, Report from the Commission to the Council and the European Parliament. Development and Implications of Patent Law in the Field of Biotechnology and genetic engineering (SEC(2005) 943), Brussels, 14.07.2005, COM(2005) 312 final, whereby the question was put forward "whether patents on gene sequences (DNA sequences) should be allowed in accordance with the classical model of patent claim, whereby a first inventor can claim an invention which covers possible future uses of that sequence, or whether the patent should be restricted so that only the specific use disclosed in the patent application may be claimed ("purpose-bound protection")" (See Point K of the text adopted).
} 
(Articles 8, 9, 10 and 11 of the Directive) and that a narrow scope might find support as well (Article 5 (3) and Recitals 23 and 25 of the Directive). ${ }^{193}$ Next to the Commission, the European Parliament intervened in the debate and called on the EPO and the EU member states to introduce a restricted scope of patents on DNA sequences, and, more especially, "to grant patents on human DNA only in connection with a concrete application and for the scope of the patent to be limited to this concrete application so that other users can use and patent the same DNA sequence for other applications (purpose bound protection)". ${ }^{194}$

At present, most EPO contracting states have opted for the conventional absolute protection regime and only a few countries, such as France and Germany, have given effect to the cry for limited product protection in the field of genetics. ${ }^{195}$

\section{Policy lever}

The use of the absolute product protection doctrine by some EPC contracting states to expressly delimit the scope of patents in the area of genetics and introduce purpose bound protection, turns this doctrine into a national statutory macro policy lever. In the purpose bound approach, only the specific (disclosed) purpose of a substance is protected by a patent and any newly found purpose should be subject of a new patent application. Such an approach is motivated by the desire to restrict the stifling effect of gene patents on innovation, and to safeguard the incentive for the development of new applications.

\subsubsection{Clarity of claims}

\section{In general}

European patent law requires that the claims "shall define the matter for which protection is sought" and that they "shall be clear and concise and be supported by the description." (Article 84 EPC). The Boards of Appeal have repeatedly added that claims have to be clear for the sake of legal certainty, as their purpose is to enable the protection conferred by the patent to be determined. ${ }^{196}$

The EPC further prescribes that the claims shall define the matter for which protection is sought "in terms of the technical features of the invention" (Rule 43 (1) EPC IRs). EPO case

193 The Commission intended to monitor for any economic consequences of possible divergences between Member States' legislation on this point, but so far, no such studies have been announced.

${ }^{194}$ European Parliament, European Parliament resolution on patents for biotechnological inventions, Strasbourg, 26 October $2005 \quad$ (P6_TA-PROV(2005)0407), $\quad$ Point 5 (see www.europarl.eu.int/omk/sipade3?SAME LEVEL=1\&LEVEL=0\&NAV=S\&DETAIL $=\& P U B R E F=-$

//EP//TEXT+TA+P6-TA-2005-0407+0+DOC+XML+V0//EN). The European Parliament further called on the Commission to examine whether this interpretation of the Directive can be achieved by means of a recommendation to the Member States or whether it requires an amendment of the Directive.

${ }^{195}$ For more details, see Van Overwalle, G. 'The Implementation of the Biotechnology Directive in Belgium and its Aftereffects. The Introduction of a New Research Exemption and a Compulsory License for Public Health', International Review of Intellectual Property and Competition Law (IIC), 2006, 889-920. Also see Timo Minssen, Es bleibet dabei: Eine schwedische Stellungnahme zur europäischen Debatte über den absoluten Erzeugnisschutz bei der DNA-Patentierung, Klinische Forschung and Recht, 2008, Heft 3 \& 4, p. 93-112.

${ }^{196}$ EPO Technical Board of Appeal (T 337/95), OJ EPO 1996, 628 relating to European patent application EP901033381 concerning 3-(substituted phenyl)pyrazole derivatives, salts thereof, herbicides therefrom, and process for producing said derivatives or salts. The Board emphasizes that claims have to be clear to ensure "that the public is not left in any doubt as to which subject matter is covered by a particular patent and which is not. This is one aspect of legal certainty which is a principle of paramount importance in any system where the rights of the public are affected by the granting of a monopoly (see J 34/92, not published in the OJ EPO, No. 4.1 of the Reasons for the Decision)" (Point 2.4 of the Reasons). For similar cases, see EPO, Case Law of the Boards of Appeal, 2006, 186. 
law has added that Article $84 \mathrm{EPC}$ has to be interpreted as meaning not only that a claim must be comprehensible from a technical point of view, but also that it must define the object of the invention clearly, that is to say, indicate all the essential features thereof: all features which are necessary for solving the technical problem with which the application is concerned have to be regarded as essential features. ${ }^{197}$

\section{In chemistry}

In chemistry, European patents have sometimes been awarded with a scope that is unclear. A typical example is the use of the term 'active ingredient'. In a case relating to the production of a concentrated aerosol space spray, claiming "a composition essentially comprising 20$85 \% \mathrm{w} / \mathrm{w}$ active ingredient in adjunct with suitable propellants" ${ }^{\prime 198}$, the Board decided that the term 'active ingredient' was unclear, hence contrary to Article 84 EPC. ${ }^{199}$ Another example is the use of the term 'substantially pure'. In a case claiming "a substantially pure piperidine derivative", ${ }^{200}$ the Board concluded that since there does not exist any unequivocal generally accepted meaning in the relevant art for the feature 'substantially pure', this feature casts doubts as to the actual subject matter covered by the claim and is to be considered unclear and contrary to Article 84 EPC. ${ }^{201}$

\section{In biotechnology}

The clarity of European biotech patent claims has quite often been subject of disputes as well. A well known example was the use of the term 'higher' in the context of the production of erythropoietin. Here, the Board took the view that what was to be measured was clear, namely values of the molecular weight of urinary EPO, hence Article 84 EPC was not violated. ${ }^{202} 203$

\footnotetext{
${ }^{197}$ See EPO, EPO, Case Law of the Boards of Appeal, 2006, 189.

${ }^{198}$ The full claim (Claim 1 of WO 9204419 (A1)) runs as follows: "a dispenser for space spraying consisting of a container comprising a metering device, and a composition essentially comprising $20-85 \% \mathrm{w} / \mathrm{w}$ active ingredient in adjunct with suitable propellants, solvents and other adjuvants" (Claims not available for EP 0591195 (A1), only for corresponding WO patent application).

199 EPO Technical Board of Appeal (T 586/97), 14 September 2000, relating to European patent application 591.195 concerning a concentrated aerosol space spray. The Board stated that when an essential ingredient comprised in a chemical composition is open to be labeled arbitrarily "active ingredient" or not depending exclusively on the mental label the user wishes to apply, thereby rendering the meaning of that feature protean, then the public is left in doubts as to the distinction which compositions are covered by the claim and which are not, which is at variance with the principle of legal certainty. Because of that lack of legal certainty, the claim fails to meet the requirement of clarity imposed by Article 84 EPC. (Point 4.1.2.2 of the Reasons).

${ }^{200}$ Claim 1 of European patent application with publication no 723.958 concerning substantially pure piperidine derivative compounds.

${ }^{201}$ EPO Technical Board of Appeal (T 728/98), 12 May 2000, OJ EPO, 2001, 319, relating to European patent application with publication no 723.958 .

${ }^{202}$ EPO Technical Board of Appeal (T 412/93), 21 November 1994, relating to European patent 148.605 (B1) concerning the production of erythropoietin and awarded to Kirin Amgen. Most relevant here is claim 20: "A polypeptide having part or all of the primary structural conformation of human or monkey erythropoietin as set forth in Table VI or Table V or any allelic variant or derivative thereof possessing the biological property of causing bone marrow cells to increase production of recticulocytes and red blood cells and to increase hemoglobin synthesis or iron uptake and characterized by being the product of procaryotic or eucaryotic expression of an exogenous DNA sequence". The dispute related to claim 19 of auxiliary request 11, which was based on Claim 20 as granted amended by the addition at the end of the claim of the feature "and which has higher molecular weight by SDS-PAGE from erythropoietin isolated from urinary sources". This amendment was objected to by some appellants for lack of clarity: use of a term such as "higher" made this feature unclear and contravenes Article 84 EPC. The Board underlined, however, that what is to be measured is clear. "Values of the molecular weight of u-EPO measured by SDS-PAGE were part of the prior art. Frequently where something has to be measured there will be a grey area where measurement error may make it difficult to
} 
However, in many biotech cases, it is by far not clear what some terms mean. A key example is the use of the term 'isolated'. According to the EU Biotechnology Directive sequences are patentable if 'isolated' from the human body (Article 5 (2) EU Biotechnology Directive). Following an in depth analysis of diagnostic gene patents, we found that the term 'isolated' was seldom clarified in the patent description, and if a definition was provided, instead of providing clarity, the intended meaning was often further obscured due to the use of unclear or broad terms in the definition itself, such as 'substantially'. ${ }^{204}$

Unclarity also reigns with regard to the terms employed to depict nucleic acid sequences. Such sequences may appear as DNA sequences, cDNA sequences, RNA sequences, short fragments, primers, probes and so forth. To determine the exact scope of the granted claim, and determine the freedom to operate - e.g. whether or not the use of a cDNA when performing a genetic diagnostic test, infringes upon the nucleic acid sequence at stake - it should be identified what acts fall under the term 'product' and under the term 'use', ${ }^{205}$ which, in this area, is not straightforward. ${ }^{206}$

\section{Policy lever}

The demand for clear patent claims is put forward for any invention, in whatever technological field. It might well be that in 'new' technological fields, the requirement is applied more loosely, as no consensus has been reached yet on the exact description of terms and concepts employed. The clear claims requirement may then be employed as a judicial micro policy lever. Patent landscaping studies in the field of gene patents indeed suggest that unclear terms are often used. ${ }^{207}$ The downside of applying the clarity of claims doctrine with some flexibility, is that it creates vagueness about the exact scope of the claims, and, consequently, increases legal uncertainty.

\subsubsection{Breadth of claims}

\section{In general}

In US patent law the breadth of claims is discussed in ${ }^{208}$ In the US pioneering patents have traditionally been given wide protection, allowing broad claims. ${ }^{209}$ However, the pioneer patent rule has not been invoked by the Federal Circuit in recent years. ${ }^{210}$

determine whether a particular product falls within a claim or not. This does not justify an objection under Article 84 EPC" (Point 60 of the Reasons).

${ }^{203}$ In a previous case (the aerosol space spray, EPO Technical Board of Appeal (T 586/97), 14 September 2000, relating to European patent application 591.195, see previous footnote) the Board decided differently. In the absence of any unambiguous reference point, a relative term such as "lower alkyl" in the field of organic chemistry does not have a generally accepted meaning with respect to its maximum number of carbon atoms, such a term is ambiguous and therefore not suitable for clearly defining the subject matter for which protection is sought in a claim which is directed to a group of organic compounds per se (EPO Technical Board of Appeal (T 586/97), 14 September 2000, relating to European patent application 591.195 (Point 2.8 of the Reasons).

${ }^{204}$ HUYS, I., BERTHELS, N., MATTHIJS, G. and VAN OVERWALLE, G., 'Legal Uncertainty in the Area of Genetic Diagnostic Testing', 27, Nature Biotechnology, October 2009, 903-909.

${ }^{205}$ Cf. Article 28 (1) (a) TRIPs Agreement: "A patent shall confer on its owner the following exclusive rights: (a) where the subject matter of a patent is a product, to prevent third parties not having the owner's consent from the acts of: making, using, offering for sale, selling, or importing for these purposes that product" (My Italics).

${ }^{206}$ Ibidem.

${ }^{207}$ See HUYS, I., BERTHELS, N., MATTHIJS, G. and VAN OVERWALLE, G., 'Legal Uncertainty in the Area of Genetic Diagnostic Testing', 27, Nature Biotechnology, October 2009, 903-909. (previous footnote). Also see Holman, C.M., 'The Impact of Human Gene Patents on Innovation and Access: A Survey of Human Gene Patent Litigation', 76 University of Missouri-Kansas City Law Review, 2007, 295-362. previous footnote ${ }^{208}$ Check with Chisum on Patents 
In European patent law the demand that claims shall be "supported by the description" (Article 84 EPC) is interpreted to mean that there must be a basis in the description for the subject matter of every claim and that "the scope of the claims must not be broader than is justified by the extent of the description and drawings and also the contribution to the art". ${ }^{211}$ In other words, it is the definition of the invention in the claims that needs support.

According to EPO case law, this requirement reflects the general legal principle that the extent of the patent monopoly, as defined by the claims, should correspond to the technical contribution to the art in order for it to be supported or justified. This means that the definitions in the claims should essentially correspond to the scope of the invention as disclosed in the description: the claims should not extend to subject matter which, after reading the description, would still not be at the disposal of the person skilled in the art. ${ }^{212}$

Even though European patent law sets forth that claims and scope must correspond, a certain degree of generalization is commonly accepted. ${ }^{213}$ Moreover, inventions which open up a whole new field are entitled to more generality in the claims than inventions which are concerned with advances in known technology. ${ }^{214}$ Thus, European patent law is willing to provide wide protection for pioneering inventions as well.

\section{In biotechnology}

In the early days of plant biotechnology, European patents have been awarded wide claims. A typical example is one of the very first plant patents granted in 1989 to Lubrizol Genetics, with patent claims for genetically modified "plant cells" ${ }^{215}$ and "plants". ${ }^{216}$ The claims had been awarded, notwithstanding the fact that the description only disclosed transformation of only two varieties of a plant, namely sunflower and tobacco. ${ }^{217}$ Similar claims were granted for other Agrobacterium-tumefaciens-mediated gene modification systems and the resulting transformed "plant cells" and "plants". ${ }^{218}$ Also in these cases, claims encompassing the whole

${ }^{209}$ Burk \& Lemley, The Patent Crisis, 2009, 127 with the references cited in footnote 102. Check with Chisum on Patents

${ }^{210}$ Burk \& Lemley, The Patent Crisis, 2009, 127.

${ }^{211}$ EPO Guidelines 2010, Part C-III-6.1.

${ }^{212}$ EPO Technical Board of Appeal (T 409/91) 18 March 1993, OJ EPO 9/1994, 653 relating to European patent 261.958 concerning middle distillate compositions with reduced wax crystal size (Point 3.3 of the Reasons). Also see EPO Guidelines 2010, Part C-III-6.1.

${ }^{213}$ See EPO Guidelines 2010, Part C-III-6.2: "Most claims are generalisations from one or more particular examples. The extent of generalisation permissible is a matter which the examiner must judge in each particular case in the light of the relevant prior art. ... A fair statement of claim is one which is not so broad that it goes beyond the invention nor yet so narrow as to deprive the applicant of a just reward for the disclosure of his invention. The applicant should be allowed to cover all obvious modifications of, equivalents to and uses of that which he has described. In particular, if it is reasonable to predict that all the variants covered by the claims have the properties or uses the applicant ascribes to them in the description, he should be allowed to draw his claims accordingly."

${ }^{214}$ EPO Guidelines 2010, Part C-III-6.2.

${ }^{215}$ See claim 19 of European patent 122.791 (B1) entitled Plant gene expression, which runs as follows: "A plant cell produced according to the method of any of Claims 10-18".

${ }^{216}$ See claim 20 of European patent 122.791 (B1), which runs as follows: "A plant or plant tissue grown from a plant cell according to claim 19".

${ }_{217}$ See the description of European patent 122.791 (B1), stating that "The invention is exemplified by the introduction and expression of phaseolin, a major seed storage protein of beans, into sunflower and tobacco plant tissues".

${ }^{218}$ See claim 4 of European patent 120.515 (BA) concerning a process for the incorporation of foreign DNA into the genome of dicotyledonous plants awarded to Leiden University, claiming "plants and plant cells obtained after the genetic properties of the original plants c.q. plant cells have been modified with application of the process according to claim 1". Also see claim 19 of European patent 126.546 (B1) from Lubrizol Genetics, 
plant kingdom were awarded, including both dicotyledonous ánd monocotyledonous plants, even though the experiments described in the patent specification were related to a few varieties of plants only, mostly potatoes, tomatoes, carrots, alfalfa and/or sunflowers.

Wide claims were also granted at the onset of animal biotechnology. The most prominent example here is the patent granted for the Harvard onco-mouse, with claims for "non-human mammalian animal" 219 , even though the description only discloses experiments with mice. ${ }^{220}$ The application and grant of these pioneering plant and animal patents, gave rise to a great deal of EPO jurisprudence. However, the disputes mostly revolved around the eligibility of animals for patent protection ${ }^{221}$ and hardly ever focused on the width of the claims at hand. ${ }^{222}$ Broad formulation can also be witnessed in the area of human genetics, even today. Patents relating to human genes, quite often encompass broadly formulated gene claims, covering many types of genes. ${ }^{223}$ Gene patents often include broad method claims as well, claiming the link between a mutation and a disease, without specifying steps as to how this link is determined. A typical example here is the claim related to the testing for Spinocerebellar

claiming "a plant, a plant tissue, or a plant cell produced according to the method of any of Claims 9-18" and stating once again that "the invention is exemplified by introduction and expression of a structural gene for phaseolin, the major seed storage protein of the bean Phaseolus vulgaris L., into sunflower and tobacco plant cells". Also see claim 8 of European patent 131.620 (B1), entitled Genetically transformed plants and awarded to Monsanto, claiming "a seed obtained from a plant produced by the method of any of claims 5 tot 7", and stating that "[...] this invention is likely to be useful to transform cells from any type of plant which can be infected by bacteria from the genus Agrobacterium. It is believed that virtually all dicotyledonous plants, and certain monocots, can be infected by one or more strains of Agrobacterium. [...] Certain types of plant cells can be cultured in vitro and regenerated into differentiated plants using techniques known to those skilled in the art. Such plant types include potatoes, tomatoes, carrots, alfalfa and sunflowers". For more, see VAN OVERWALLE, G., Octrooieerbaarheid van plantenbiotechnologische uitvindingen - Patentability of Plant Biotechnological Inventions (Substantive Summary), Brussels, Bruylant, 1996, 739 p.

${ }^{219}$ See claim19 of European patent 169.672 (B1), entitled "Method for producing transgenic animals", claiming "a transgenic non-human mammalian animal whose germ cells and somatic cells contain an activated oncogene sequence as a result of chromosomal incorporation into the animal genome, or into the genome of an ancestor of said animal, said oncogene optionally being further defined according to any one of the claims 3 to 10 ".

${ }^{220}$ For more, see VAN OVERWALLE, G., The Legal Protection of Biotechnological Inventions in Europe and in the United States. Current Framework and Future Developments, in Leuven Law Series, Leuven, University Press, 1997, 78 p.

${ }^{221}$ More in particular in the light of the exclusion of plant and animal varieties in Article 53 (b) EPC, now interpreted somewhat more liberally thanks to the EU Biotechnology Directive (Article 4) and its EPC counterpart (Rule 27 EPC IRs: "Biotechnological inventions shall also be patentable if they concern: (b) plants or animals if the technical feasibility of the invention is not confined to a particular plant or animal variety"). For more on the chain of case law on plant and animals patents, see Van Overwalle, 1996 (previous footnote); Van Overwalle, 1997 (previous footnote) and VAN OVERWALLE, G., 'Biotechnology and Patents: Global Standards, European Approaches and National Accents', in Genetic Engineering and the World Trade System, Daniel WÜGER and Thomas COTTIER (eds.), Cambridge University Press, 2008, 77-108.

${ }^{222}$ In the Harvard onco-mouse case, breadth of claims was indeed an issue, and after intense debates the claim was narrowed down to rodents (EPO Opposition Division, 7 November 2001) and later to transgenic mice (EPO Technical Board of Appeal (T 0315/03), 6 July 2004), mainly on ethical grounds (Article 53 (a) EPC), more in particular animal suffering.

${ }^{223}$ Cf. Thomas B. Kepler, Colin Crossman \& Robert Cook-Deegan, Metastasizing patent claims on BRCA1, Genomics, 2010. Many patents make claims on DNA sequences; some include claims on oligonucleotides related to the primary patented gene. Kepler et al. used bioinformatics to quantify the reach of one such claim from US patent 4.747.282 on BRCA1. The found that human chromosome 1 (which does not contain BRCA1) contains over 300,000 oligonucleotides covered by this claim, and that $80 \%$ of cDNA and mRNA sequences contributed to GenBank before the patent application was filed also contain at least one claimed oligonucleotide. Any "isolated" DNA molecules that include such 15 bp nucleotide sequences would fall under the claim as granted by the US Patent and Trademark Office. Anyone making, using, selling, or importing such a molecule for any purpose within the United States would thus be infringing the claim. This claim and others like it turn out, on examination, to be surprisingly broad, and if enforced would have substantial implications for medical practice and scientific research. 
ataxia 6 (SCA6) demanding protection for "a method of determining whether an individual has or is at risk for developing spinocerebellar ataxia type 6 (SCA-6), comprising assessing whether the number of CAG nucleotide repeat units in the alpha1A calcium channel subunit gene of said individual is greater than a control number, thereby indicating that said individual has or is at risk for developing SCA6)"224, and thereby referring to the use of "any" test. In view of the prevailing patentability criteria it should be almost impossible to construe claims so broadly that they would cover an indefinite number of tests. ${ }^{225}$ However, the examples show that nevertheless, such overly broad claims are granted. ${ }^{226}$

\section{Policy lever}

The pioneering patent rule and related breadth of claim doctrine is a judicial micro policy lever. Application of the nominally neutral rule is likely to result in differing claim language and differing patent protection in different industries. Burk and Lemley suggest that the rule produces effect in the pharmaceutical industry where innovation is likely to take the form of discrete new inventions opening up entire fields of inquiry and new markets for treatment of an illness or disease. By contrast, industries such as software, are characterized by incremental improvements. ${ }^{227}$ This view should be put in perspective for two reasons. First, recent surveys point out that a lot of incremental improvements equally take place in the pharmaceutical sector as well, leading to so called evergreening. ${ }^{228}$ More importantly, rather than suggesting that the pioneering patent rule creates differences among industries, the pioneering rule may lead to differences in one and the same industry, favoring research and development in the explorative and pioneering high days within that industry, and reluctantly accommodating advances in later years. So, broad claims are more likely to be accepted in 'new' technology fields, such as the early days of biotechnology, rather than in 'known' technologies, such as the later stages within those areas of biotechnology which have already been widely explored.

Moreover, it may be doubted that the pioneering patent rule is always applied consistently, even within the same (stage within an) industry. ${ }^{229}$

\subsection{Patent rights and limitations}

\subsubsection{Research exemption}

224 Claim 1 of European patent 1.015.628 providing a method of screening individuals at risk for developing diseases caused by trinucleotide repeat sequence instability.

${ }^{225}$ See HUYS, I., BERTHELS, N., MATTHIJS, G. and VAN OVERWALLE, G., 'Legal Uncertainty in the Area of Genetic Diagnostic Testing', 27, Nature Biotechnology, October 2009, 903-909.

${ }^{226}$ Ibidem.

${ }^{227}$ Burk \& Lemley, The Patent Crisis, 2009, 127-128.

228 See the Final Report of the Pharmaceutical sector inquiry, 8 July 2009 (available at http://ec.europa.eu/competition/sectors/pharmaceuticals/inquiry/index.html).

${ }^{229}$ As we have clearly demonstrated, the EPO grants wide protection for transgenic plants: based on experiments with only a few plant varieties, claims were awarded for "plants". This seems at odds with the instructions in the EPO Guidelines 2010, more in particular the example relating to "plant seedlings": "The question of support is illustrated by the following example: (i) seedlings" by subjecting them to a controlled cold shock so as to produce specified results, whereas the description discloses the process applied to one kind of plant only. Since it is well-known that plants vary widely in their properties, there are well-founded reasons for believing that the process is not applicable to all plant seedlings. Unless the applicant can provide convincing evidence that the process is nevertheless generally applicable, he must restrict his claim to the particular kind of plant referred to in the description. A mere assertion that the process is applicable to all plant seedlings is not sufficient". (EPO Guidelines 2010, Part C - Chapter III - 6.3.) 


\section{In general}

In the US the research exemption exists as a judicially created theory. ${ }^{230}$ The exception has recently been narrowed down considerably in the landmark case Madey v. Duke University. ${ }^{231}$ In Madey v. Duke University - which in fact involved electron laser technology - it was recalled that "Regardless of whether a particular institution or entity is engaged in an endeavor for commercial gain, so long as the act is in furtherance of the alleged infringer's legitimate business and is not solely for amusement, to satisfy idle curiosity, or for strict philosophical inquiry, the act does not qualify for the very narrow and strictly limited experimental use defense." Furthermore, the profit or nonprofit status of the user is not decisive for the applicability of the doctrine.

In Europe, the research exemption is phrased as a statutory restriction to the rights of the patent holder. The original European "mother" provision states that the rights that are conferred by a patent shall not extend to "acts done for experimental purposes relating to the subject matter of the patented invention". ${ }^{232}$ The equivalent provisions in the European member states mirror but sometimes deviate from this wording. Because different national legislations and court rulings exist, the exact scope of the exemption differs from country to country. There seems to be a general consensus that the exemption applies irrespective of the place of the experiment: experiments are exempted, whether they are carried in a public laboratory, a hospital or a private company. Agreement also exists with regard to the nature of the experiments: experiments 'on' the patented subject matter fall under the research exemption, whereas experiments 'with' the patented subject matter are not shielded by the exception. Doubts mainly arise with regard to the final purpose of the experiment: are only experiments with a strict non-commercial scientific goal exempted, or also experiments with a commercial or a mixed scientific/commercial objective? ${ }^{233}$

\section{In biotechnology}

In an aim to foster biotechnological innovation, and, more in particular, to shield the use of research tools ${ }^{234}$ from infringement, the patent legislator of one European member state, namely Belgium, decided to reshape and widen the research exemption. In 2005 the Belgian Patent Act was reworded to stipulate that the rights of a patent holder do not extend to "acts carried out for scientific purposes 'on' or 'with' the subject matter of the invention". ${ }^{235}$ The

\footnotetext{
${ }^{230}$ Check with Chisum on Patents

23164 USPQ2d 1737 (Fed. Cir. 2002).

${ }^{232}$ Article 27 of the Agreement relating to Community patents, done at Luxembourg on 15 December 1989 (89/695/EEC), Official Journal L 401, 30 December 1989, 1-27. The so-called Community Patent Convention has never entered into force. Discussions were resumed in 2000 in the framework of a Proposal for a Council Regulation on the Community patent, Brussels, 1.8.2000, COM(2000) 412 final (see Article 9).

${ }^{233}$ There is a vast literature on this issue. See e.g. Chrocziel, P. Die Benutzung patentierter Erfindungen zu Versuchs- und Forschungszwecken (Carl Heymanns Verlag, Köln, 1986) (in German); Cornish, W. R. Experimental Use of Patented Inventions in European Community States, IIC Int. Rev. Int. Prop. Comp. Law 29, 735-753 (1998); STRAUS, "The research exemption. The Situation in Germany", in Van Overwalle Geertrui (ed.), Octrooirecht en geneesmiddelen - Patent law and medicines, Bruylant, Brussels, 2000, 107-120; Geertrui Van Overwalle, Esther van Zimmeren, Birgit Verbeure and Gert Matthijs, Models for facilitating access to patents on genetic inventions, Nature Review Genetics, 2006, 143-148.

${ }^{234}$ Research tools are instruments, reagents, methods, and information, the main commercial value of which is furthering research, see National Research Council, Reaping the Benefits of Genomic and Proteomic Research: Intellectual Property Rights, Innovation, and Public Health, National Academies Press, Washington DC, Prepublication Copy, December 2005, pp. 51-53 (see www.nap.edu/catalog/11487.html) see previous footnote.

${ }^{235}$ New wording of Article 28 (2) of the Belgian Patent Act, introduced by the Act of 28 April 2005 to modify the Act of 28 March 1984 on Invention Patents, with Regard to the Patentability of Biotechnological Inventions,
} 
new wording aims at both exempting research 'on' and research 'with' the subject matter of the invention to guarantee a maximum freedom to operate for research activities. 'On' refers to experiments where it is verified whether the patented invention works the way it is described in the patent or whether the invention is indeed novel and inventive as claimed in the patent, in other words, experiments relating to the activity, function, usefulness or feasibility of the patented invention itself. Experiments 'with' refers to experiments where the patented invention is used to investigate something else, in other words, where the patented invention is used as an instrument, as an "Apparativ" (for instance, a patented scale which is used to weigh compounds for manufacturing a vaccine).

The new wording aims at exempting both experiments with a strict scientific purpose and acts with a mixed scientific/commercial aim. ${ }^{236}$ Indeed, in the debate on whether to opt for a strict or a wide interpretation of the notion 'scientific purpose', the Belgian legislator opts for a wide scope of interpretation. In the strict approach only acts serving a strict scientific goal, aimed at expanding knowledge or testing a proposition, are shielded from infringement. In a wide approach acts with a strict scientific or a mixed scientific and commercial goal, aimed at developing new applications, improved therapeutic effects, more effective production methods, new indications, etc. are also exempted. Purely commercial acts ${ }^{237}$ do in no way fall under the renewed research exemption. ${ }^{238}$

\section{Policy lever}

The conventional European research exemption (research-on-exemption) might well be a statutory micro policy lever, introduced to foster research and follow-on innovation across sectors, and resorting wider effect in certain sectors than others. The broadened Belgian research exemption (research-on-plus-with-exemption), can definitely be seen as a statutory macro policy lever, intended to foster innovation in a specific industry, namely the biotechnology industry. Our conclusion on this point is fully in line with the observations expressed by Burk and Lemley, that the statutory experimental-use-on -provision functions as a global policy lever, pertaining to have effect in all industry sectors, whereas the experimental-use-with-provision, although nominally industry-neutral, constitutes in fact a macro policy lever for the biotechnology industry. ${ }^{239}$

However, it remains to be seen to which extent the broadened research exception or experimental-use-with exemption will indeed fulfill its primary objective of enabling use of patented products and tools, and stimulating (mixed fundamental and commercial) research and development in the field of biotechnology. Doubtful borderline cases may arise in day-today practice. What about spin-offs originating from university-based research with

Official Gazette, 13 May 2005 (Wet van 28 april 2005 tot wijziging van de wet van 28 maart 1984 op de uitvindingsoctrooien, wat betreft de octrooieerbaarheid van de biotechnologische uitvindingen, Belgisch Staatsblad, 13 mei 2005). For an in-depth analysis of the renewed Belgian research exemption, see VAN OVERWALLE, G., 'The Implementation of the Biotechnology Directive in Belgium and its Aftereffects. The Introduction of a New Research Exemption and a Compulsory License for Public Health', 37 International Review of Intellectual Property and Competition Law (IIC), 2006, 889-920.

${ }^{236}$ Provided that mixed research is mainly scientific in nature, which excludes companies with mainly commercial goals, from the scope of the exemption, see the Statement of the Minister for Economic Affairs, Verwilghen, on the scope of research exemption, Parl. Doc., Chamber, 2004-2005, DOC 51 1348/006, p. 59. Also see, Parl. Doc., Senate, 2004-2005, 3-1088/3, p. 2.

${ }^{237}$ E.g. the preparation of the registration dossier for clinical trials and acts required in order to be eligible for a license to commercialize so-called me too-medicines.

${ }^{238}$ However, the preparation of the registration dossier for clinical trials are exempted from patent infringement under European Directive 2004/27/EC of the European Parliament and the Council of 31 March 2004 and the equivalent Belgian variant of the so-called 'Bolar' exemption.

${ }^{239}$ Burk and Lemley, the Patent Crisis, 2009, 113. 
commercial objectives? Or pharmaceutical and/or biotechnology companies having a clearcut commercial mission, but hosting large research activities as well? But, more importantly, there might be a tremendous downside to establishing a wide experimental-use-with exemption. Trade secret protection might increase or - even worse - research activities might be stifled, in those sectors where new research tools are being developed, as a result of the fact that the prospect of an adequate patent protection is being eroded. ${ }^{240}$

\subsubsection{Compulsory licensing}

In general

Many countries around the world allow compulsory licenses in their national legislation granted. In Europe, national legislators have traditionally introduced compulsory licenses for failure to work patents, dependency of patents and public interest motives, such as national economy, national security or national emergency. ${ }^{241}$

The US is often thought of as one of the few countries without compulsory license mechanisms. But in fact, in a limited number of cases, US courts or government officials may grant compulsory licenses on the basis of specific legal provisions. ${ }^{242}$ Furthermore, in US patent and antitrust cases the actual effect of a refusal of a judge to grant an injunction to the patent owner, or an order to license out will be that the alleged infringer can continue using the patented subject matter under the conditions set by the court without the authorization of the patent owner. Hence, the ultimate effects are similar to the grant of a compulsory license. $^{243}$

\section{In biotechnology}

In the aftermath of the Myriad controversy, ${ }^{244}$ various European countries have adjusted existing compulsory license regimes, or designed additional compulsory license mechanisms to remedy problems resulting from or restrictive licensing practices in the area of genetics, in particular in the field of genetic testing. In France the existing compulsory license for public

\footnotetext{
${ }^{240}$ See VAN OVERWALLE, G., Research Tools in the R\&D Phase. Belgian Report Prepared for The Institute for Future Technology (IFTECH) and Commissioned by the Japanese Patent Office, March 102008,40 p.

${ }^{241}$ For an in-depth analysis of the history, the grounds, the application procedure and the scope of the various types of compulsory licenses, see Esther van Zimmeren and Geertrui Van Overwalle, in Encyclopedia for Life Support Systems (EOLSS) (Theme Biotechnology - Topic Medical Biotechnology), DOELLE, H.W. and ROKEM, J. S. (eds.) (see http://www.eolss.net) (40 p).

242 E.g. government use, 28 U.S.C. $\S 1498 ;$ Atomic Energy Act, 42 U.S.C. $\S 2183$, Clean Air Act, 42 U.S.C. § 7608; Plant Variety Protection Act, 7 U.S.C. $§ 2404$ and the "march in right" in the so-called BayhDole Act, 35 USC § 203.

${ }^{243}$ Esther van Zimmeren and Geertrui Van Overwalle, in Encyclopedia for Life Support Systems (EOLSS) (Theme Biotechnology - Topic Medical Biotechnology), DOELLE, H.W. and ROKEM, J. S. (eds.) (see http://www.eolss.net) (40 p) see previous footnote

${ }^{244}$ Myriad Genetics obtained several European and US patents for the screening of breast cancer genes, but licensed the test exclusively to a limited number of commercial genetic laboratories within specific geographical regions. This highly restrictive licensing policy gave rise to a strong and worldwide reaction. There is a vast literature on the European response to the Myriad patents. The interested reader might care to take a look at Matthijs, G. \& Halley, D. European-wide opposition against the breast cancer gene patents. Eur. J. Hum. Genet. 10, 783-784 (2002); Herrlinger, K. A. Die Patentierung von Krankheitsgenen (Carl Heymanns Verlag, Köln, 2005); Walpole, I. R., Dawkins, H. J. S., Sinden, P. D. \& O'Leary, P. C. Human gene patents: the possible impacts on genetic services healthcare. Med. J. Aust. 179, 256-283 (2003); VAN OVERWALLE, G., 'IPR Issues and High Quality Genetic Testing', in Quality Issues in Clinical Genetic Services, Kristoffersson, U., Schmidtke, J. and Cassiman, J.-J. (eds.), Springer, 2010.
} 
interest was broadened to include genetic diagnostics in $2004^{245} 246$ and in Belgium a new compulsory license for public health was introduced in the Patent Act in $2005 .{ }^{247}$ Such compulsory license is considered legitimate for reasons of public health if the quantity or the quality of medicines or methods available to the public is insufficient, if medicines or methods are only available at abnormally high prices, if the patent is exploited in a manner contrary to public health interests or if the patent is worked in a manner resulting in anticompetitive practices qualified as such in a final administrative or court decision. ${ }^{248}$ The compulsory license can not only be invoked against obstructive patents in the field of diagnostics but also against patents in the pharmaceutical field at large. More in particular compulsory licenses can be granted with respect to patents issued for "medicines, medical devices, in vitro diagnostic medical devices, related therapeutic products, processes for obtaining such products, products necessary in obtaining these products, processes for manufacturing such products and ex vivo diagnostic methods". 249250251

245 Article 18 of Act no 2004-800 of 6 August 2004 (French OJ of 7 August 2004) and Article 10 of Act no 2004-1338 of 8 December 2004 (French OJ 9 December 2004), both available at http://www.légifrance.fr.

${ }^{246}$ Switzerland also included a separate compulsory license in case of anti-competitive practices with regard to diagnostic products or processes, see Act of June 222007 to modify the Patent Act of June 25 1954, AS 2008, 2551-2584, available at http://www.admin.ch/ch/d/as/2008/2551.pdf. The Swiss regime will not be further discussed here. For more, see Christophe Germann, 'The Swiss Approach to Compulsory Licensing for Diagnostic Products and Processes' in Gene Patents and Public Health, VAN OVERWALLE, G. (ed.), Brussels, Bruylant (2007), 149-158; van Zimmeren and Geertrui Van Overwalle, in Encyclopedia for Life Support Systems (EOLSS) (Theme Biotechnology - Topic Medical Biotechnology), DOELLE, H.W. and ROKEM, J. S. (eds.) (see http://www.eolss.net) (40 p) (in press).

${ }^{247}$ Article 31 bis of the Belgian Patent Act, introduced by the Act of April 282005 to modify the Act of March 281984 on Invention Patents, with regard to the Patentability of Biotechnological Inventions, Official Gazette, May 13, 2005. For an in-depth analysis of the history, scope and application procedure of this newly designed license, see DEBRULLE, J., DE CORT, L. \& PETIT, M., 'La licence obligatoire belge pour raisons de santé publique' in Gene Patents and Public Health, VAN OVERWALLE, G. (ed.), Brussels, Bruylant (2007), 161198 (with a summary in English on pages 199-209); VAN OVERWALLE, G., 'The Implementation of the Biotechnology Directive in Belgium and its After-Effects. The Introduction of a New Research Exemption and a Compulsory License for Public Health', (2006) IIC 37, 889-919. see previous footnote

${ }^{248}$ Article L.613-16 of the French IP Code. The Belgian Patent Act stipulates that "[in] the interest of public health, the King, by decree established after consultation in the Council of Ministers, can grant a license for the exploitation and application of an invention protected by a patent" (our italics) (Article 31 bis $\S 1$ ). Additionally, some examples where the public health interest is at stake were put forward in a later Ministerial Statement. These examples are largely a reflection of the examples provided in the French IP Code. The proposal to include this more detailed wording also in the Belgian Patent Act in order to increase the transparency and the strength of the provision was refused. So, rather than defining the notion 'public health' in the patent act, the concept is clarified by providing some examples in a political statement.

${ }^{249}$ Article L.613-16 of the French IP Code. In the Belgian Patent Act the scope of application has been modeled after the French system. Compulsory licenses can be granted for "a) a medicine, a medical device, a medical device or product for diagnosis, a derived or combinable therapeutic product; b) the process or product necessary for the fabrication of one or more products indicated under a); and c) a diagnostic method applied outside the human or animal body" (Article 31 bis $\S 1$ of the Belgian Patent Act). Translation provided by Van Overwalle \& Haasl, VAN OVERWALLE, G. (ed.), Gene Patents and Public Health, Brussels, Bruylant (2007).

${ }^{250}$ One of the reasons why the field of application of the compulsory license regime was broadened from diagnostics to pharmaceuticals, was to avoid the criticism that the new regime runs counter to the nondiscrimination prescription of TRIPS. Some have argued, however, that this was not necessary, as the TRIPs rule only applies to the grant of patent rights (article 27 TRIPs), not to the exercise of patent rights (article 28 TRIPs).

${ }^{251}$ In addition to national initiatives to solve domestic public health problems, European legislation has been introduced to aid developing countries with health problems. A European Regulation on compulsory licensing of patents relating to the manufacture of pharmaceutical products for export to countries with public health problems was accepted in 2006 (Regulation (EC) No 816/2006 of the European Parliament and of the Council of 17 May 2006 on compulsory licensing of patents relating to the manufacture of pharmaceutical products for export to countries with public health problems, Official Journal L. 157/1, 9 June 2006 (available at http://eurlex.europa.eu/en/index.htm, 14 February 2007) obliging Member States to grant a compulsory licence for the manufacture and sale of patented pharmaceutical products for export to countries without or with insufficient 


\section{Policy lever}

The traditional compulsory license regimes for non working and dependency are statutory micro policy levers. These license mechanisms have been designed to "prevent the abuses which might result from the exercise of the exclusive rights conferred by the patent" ${ }^{\text {,252, }}$ irrespective of the sector or area where these abuses might emerge. It is quite likely, however, that the compulsory license for dependency will be employed more in sectors characterized by follow-on innovation than other industries. The newly shaped compulsory license regime for public health is definitely a statutory macro policy lever. Although initially designed as a measure to resolve problems in the area of genetics, it is conceived as a remedy to solve problems in the pharmaceutical field at large.

Rather than a direct measure to seize abusive patent holders, the compulsory license may act as an indirect policy instrument with a preventive and dissuading effect towards patent holders applying (extremely) restrictive licensing policies and may compel a non-cooperative patent holder to enter into fair and reasonable licensing negotiations. It is exactly this preventive threat function which may turn the compulsory licensing mechanism into more than just another tool of symbolic law-making.

\subsubsection{Patent term}

\section{In general}

US patent law sets forth that a patent shall last for 20 years from the date on which the patent application was filed (35 USC 154 (a) (2)). In the same line, European patent law prescribes that the term of the European patent shall be 20 years from the date of filing of the application (article $\left.63\left(1^{\circ}\right) \mathrm{EPC}\right)$.

\section{In medicine and biotechnology}

From 1991 onwards, EPC contracting states can extend the term of a European patent, under the same conditions as those applying to national patents, if the subject matter of the European patent is a product or a process for manufacturing a product or a use of a product which has to undergo an administrative authorization procedure required by law before it can be put on the market in that state (article 63 (2) EPC). As a result, various EU member states have promulgated an extension regime of maximum 5 years in the pharmaceutical sector ${ }^{253}$ (resulting in so-called supplementary protection certificates), extendable with an extra 6

production facilities in the pharmaceutical sector so long as a number of conditions are fulfilled. For some more background information, see Vandoren, P., and Ravillard, 'A New EC Initiative to Allow Export of Medicines under Compulsory Licences to Poor Countries', 2005 The Journal of World Intellectual Property, 103-121. Also see WTO, Compulsory licensing of pharmaceuticals and TRIPS. Frequently Asked Questions (available at www.wto.org/english/tratop e/trips e/public health faq e.htm).

${ }^{252}$ Article 5.A.2 Paris Convention.

${ }^{253}$ Council Regulation (EEC) 1768/92 of 18 June 1992 concerning the creation of a supplementary protection certificate for medicinal products, Official Journal European Union L 182, 2 July 7 1992, p. 1. For an in-depth analysis, see Octrooirecht en geneesmiddelen [Patent law and medicines],Brussel, Bruylant, 2001. A similar extension regime of 5 years has been introduced for plant protection products, see Regulation (EC) No 1610/96 of the European Parliament and of the Council of 23 July 1996 concerning the creation of a supplementary protection certificate for plant protection products, Official Journal of the EU L 198, 8.8.1996, p. 30-35. 
months for medicinal products for pediatric use. ${ }^{254}$ In the US, similar extension regimes exist for pharmaceutical patents. ${ }^{255}$

Next to regimes providing longer terms of protection in certain sectors, alternative national regimes have been put in place with shorter protection terms, amounting to so-called "petty patents", "utility models" or "Gebrauchsmuster". ${ }^{256}$ However, when harmonizing the varying national regimes on this point, ${ }^{257}$ the EU legislator clearly stated that inventions relating to biological material or to chemical or pharmaceutical substances or processes, were excluded from such protection regimes, ${ }^{258}$ because utility model protection is tailored to technical inventions involving a specific (read: lower) level of inventiveness, ${ }^{259}$ which is out of place in biology and pharma. ${ }^{260} 261$

\section{Policy lever}

The supplementary protection certificate regime is a clear example of a statutory macro policy lever. Prolongation of the patent term has been introduced explicitly to accommodate the need for an adequate term of protection in specific industries, namely industries characterized by substantial administrative authorization procedures, such as the pharmaceutical sector. The patent term extension initiative shows an increased interest from the legislator to tailor patent law to the administrative needs of particular industries, in casu

${ }^{254}$ Regulation (EC) 1901/2006 of the European Parliament and of the Council of 12 December 2006 on medicinal products for paediatric use and amending Regulation (EEC) 1768/92, Directive 2001/20/EC, Directive 2001/83/EC and Regulation (EC) 726/2004,Official Journal European Union, L 378/1, 17 December 2006.

${ }^{255}$ See US: Drug Prize Competition and Patent Restoration Act, 1984. Check with Chisum on Patents

${ }^{256}$ For the regime in Germany, see e.g. See Karsten Königer, 'Registration without Examination: The Utility Model - A Useful Model?' in Patents and Technological Progress in a Globalized World, Liber Amicorum Joseph Straus, 2009, 17-29; for the regime in the Netherlands, see e.g. Van Nieuwenhoven Helbach, E.A., 'Sieren gebruiksmodellen', in CIER-Lezingen. Modellenrecht, 1986-1987, A1-A15; for the regime in Belgium, see e.g. VAN OVERWALLE, G., 'Europese harmonisatie in het octrooirecht, het kwekersrecht en het gebruiksmodellenrecht: van wiel naar mens naar wieltje', Intellectuele Rechten - Droits Intellectuels (I.R.D.I.) (Benelux), 1998, 149-168.

${ }^{257}$ Proposal for a European Parliament and Council Directive approximating the legal arrangements for the protection of inventions by utility model, COM (97) 0691 final - COD 97/0356, Official Journal European Union, C 036, 3 February 1998, p. 13. Also see Amended proposal for a European Parliament and Council Directive approximating the legal arrangements for the protection of inventions by utility model (presented by the Commission in accordance with Article 250(2) of the EC Treaty), Brussels, 12 July 1999, COM (1999) 309 final $/ 2,97 / 0356$ (COD).

${ }_{258}^{25}$ See Article 4 (b) and (c) of EU Utility Model Proposal, 1997.

${ }^{259}$ Cf. Article 6 of the EU Utility Model Proposal, 1997: "For the purposes of this Directive, an invention shall be considered as involving an inventive step if, in the utility model application, the applicant indicates clearly and convincingly that, compared with the state of the art, it exhibits either (a) particular effectiveness in terms of, for example, ease of application or use; or (b) a practical or industrial advantage. $C f$. Recital 7 of the EU Utility Model Proposal, 1997: "Whereas utility model protection is better suited than patent protection to technical inventions involving a specific level of inventiveness".

${ }^{260}$ See Point 62 of the Explanatory Memorandum of the EU Utility Model Proposal, 1997: “[...] these sectors are complex ones in which property rights involving no examination as to novelty or inventive step are out of place".

${ }^{261}$ The EU Utility Model Proposal was later withdrawn, following the screening exercise of proposals on which the EU legislator had not yet reached a decision and which were found not to be consistent with the Lisbon and Better Regulation criteria, unlikely to make further progress in the legislative process or found to be no longer topical for objective reasons. See Communication from the Commission to the Council and the European Parliament 'Outcome of the screening of legislative proposals pending before the Legislator', Brussels, 27.9.2005 $\operatorname{COM}(2005) 462$ final; See 'Withdrawal of Commission Proposals Following Screening for their General Relevance, their Impact on Competitiveness and Other Aspects' (2006/C 64/03), 49 Official Journal European Union, C 6417 March 2006, 3. 
the pharmaceutical industry. Here, the extension is triggered in an attempt to achieve differentiation of amortization/return on investment possibilities.

The utility model framework is an example of a mixed statutory micro/macro policy lever. Although the utility model regime could in principle apply in all industry sectors, a major impact was expected in industries characterized by minor technical inventions, such as mechanical engineering, electrical engineering and the automotive industry ${ }^{262}$, as well as microtechnology, micromechanics, toy manufacture, clock and watch making, and optics. ${ }^{263}$ The utility model functions as a micro policy lever. And, since the utility model is expressly not made available for biological and pharmaceutical inventions, the utility model acts as a macro policy lever as well.

\section{Conclusions}

Our European tour d'horizon has now come to an end. Time has come to stand back and conclude on the pecularities of the policy levers put into operation in Europe. And sketch a few, modest lines of comparison with the US landscape.

\subsection{European policy levers in biotechnology}

\subsubsection{Policy levers}

Our study reveals that a lot of policy levers are put into operation to tailor European patent law to biotechnological innovation in Europe. In total, some seventeen policy levers have been uncovered in current European patent law which have particular effect on the biotech (or adjacent chemical and pharmaceutical) industry (see Table 2. Detailed Overview of European Policy Levers in Biotechnology). In the category of patent acquisition, policy levers concerning patentable subject matter have been put into operation, more in particular the technical character rule, the morality clause and the medical method doctrine. Levers concerning patentability requirements have also been used, by adjusting the novelty requirement (first and second medical use doctrine, selection invention rules and testing exemption), the inventive step requirement (expectation of success doctrine and secondary indicia approach), the industrial applicability standard, the skilled person doctrine and the enabling disclosure requirement. In the field of patent scope, policy levers have been handled concerning product patent claim scope, clarity of claims doctrine and breadth of claims doctrine. In the area of patent rights, policy levers have been used including the research exemption, compulsory licenses and patent term.

\begin{tabular}{|c|c|c|}
\hline CATEGORY & POLICY LEVER & TYPE OF POLICY LEVER \\
\hline \multirow{3}{*}{$\begin{array}{l}\text { 1. PATENT ACQUISITION } \\
\text { Patentable subject matter }\end{array}$} & & \\
\hline & $\begin{array}{l}\text { Inventions and } \\
\text { discoveries (technical } \\
\text { character) }\end{array}$ & $\begin{array}{l}\text { Industry neutral } \\
\text { Effect on innovation in biotechnology (human DNA) } \\
\text { Micro policy lever } \\
\text { Originally jurisprudential (EPO), now statutory (EU) }\end{array}$ \\
\hline & Morality & $\begin{array}{l}\text { Industry neutral } \\
\text { Effect on innovation in biotechnology (transgenic }\end{array}$ \\
\hline
\end{tabular}

${ }^{262}$ See Point 35 and Point 45 of the Explanatory Memorandum of the EU Utility Model Proposal 1997.

${ }^{263}$ See Point 6 of the Explanatory Memorandum of the EU Utility Model Proposal 1997. 


\begin{tabular}{|c|c|c|}
\hline \multirow{6}{*}{ Novelty } & & $\begin{array}{l}\text { plants, transgenic animals, human DNA) } \\
\text { Micro policy lever } \\
\text { Originally statutory (EPC), then jurisprudential } \\
\text { (EPO), now statutory (EU) }\end{array}$ \\
\hline & Medical methods & $\begin{array}{l}\text { Industry specific } \\
\text { Aimed at having effect on innovation in health care } \\
\text { Macro policy lever } \\
\text { Statutory (EPC) }\end{array}$ \\
\hline & First medical use & $\begin{array}{l}\text { Industry specific } \\
\text { Effect mainly on innovation in pharmaceutical } \\
\text { sector } \\
\text { Macro policy lever } \\
\text { Statutory (EPC) }\end{array}$ \\
\hline & Second medical use & $\begin{array}{l}\text { Industry specific } \\
\text { Effect mainly on innovation in pharmaceutical } \\
\text { sector } \\
\text { Macro policy lever } \\
\text { Originally jurisprudential (EPO), now statutory (EPC) }\end{array}$ \\
\hline & Selection invention & $\begin{array}{l}\text { Industry neutral } \\
\text { Effect mainly on innovation in pharmaceutical and } \\
\text { chemical sector } \\
\text { Micro policy lever } \\
\text { Jurisprudential (EPO) }\end{array}$ \\
\hline & Testing exemption & $\begin{array}{l}\text { Industry neutral } \\
\text { Effect mainly on innovation in pharmaceutical and } \\
\text { biotechnological sector } \\
\text { Micro policy lever } \\
\text { Jurisprudential (EPO) }\end{array}$ \\
\hline \multirow[t]{2}{*}{ Inventive step } & $\begin{array}{l}\text { Expectation of } \\
\text { success }\end{array}$ & $\begin{array}{l}\text { Industry neutral } \\
\text { Effect on innovation in young (vs. established) } \\
\text { industries, hence indirect effect in biotechnology } \\
\text { Micro policy lever } \\
\text { Jurisprudential (EPO) }\end{array}$ \\
\hline & $\begin{array}{l}\text { Secondary indicia - } \\
\text { commercial success }\end{array}$ & $\begin{array}{l}\text { Industry neutral } \\
\text { Effect unclear for the moment } \\
\text { Micro policy lever } \\
\text { Jurisprudential (EPO) }\end{array}$ \\
\hline Industrial applicability & Industrial applicability & $\begin{array}{l}\text { Industry specific } \\
\text { Higher standard in biotechnology (DNA) } \\
\text { Macro policy lever } \\
\text { Statutory (EU) } \\
\text { Industry neutral } \\
\text { Effect on downstream (vs. upstream) innovation } \\
\text { closer to market, hence indirect effect on } \\
\text { innovation in pharmaceutical sector } \\
\text { Micro policy lever } \\
\text { Jurisprudential (EPO) }\end{array}$ \\
\hline Skilled person & PSITA & $\begin{array}{l}\text { Industry neutral } \\
\text { Effect on innovation in new (vs. old) and advanced } \\
\text { (vs. low) technologies, hence indirect effect on } \\
\text { biotechnology } \\
\text { Micro policy lever } \\
\text { Jurisprudential (EPO) }\end{array}$ \\
\hline
\end{tabular}




\begin{tabular}{|c|c|c|}
\hline Enabling disclosure & Written description & $\begin{array}{l}\text { Industry specific } \\
\text { Higher standard in biotechnology } \\
\text { Macro policy lever } \\
\text { Originally jurisprudential (EPO), now statutory (EPC } \\
\text { IRs) }\end{array}$ \\
\hline \multirow[t]{3}{*}{ 2. PATENT SCOPE } & $\begin{array}{l}\text { Scope of product } \\
\text { claims }\end{array}$ & $\begin{array}{l}\text { Industry specific } \\
\text { Limited (purpose bound) scope in biotechnology } \\
\text { (DNA) } \\
\text { Macro policy lever } \\
\text { Statutory (national) }\end{array}$ \\
\hline & Clarity of claims & $\begin{array}{l}\text { Industry neutral } \\
\text { Effect on innovation in biotechnology (DNA) } \\
\text { Micro policy lever } \\
\text { Jurisprudential (EPO) }\end{array}$ \\
\hline & Breadth of claims & $\begin{array}{l}\text { Industry neutral } \\
\text { Effect on innovation in new (vs. known) } \\
\text { technologies, hence indirectly in biotechnology in } \\
\text { the early days } \\
\text { Micro policy lever } \\
\text { Jurisprudential (EPO) }\end{array}$ \\
\hline \multirow[t]{4}{*}{$\begin{array}{l}\text { 3. PATENT RIGHTS AND } \\
\text { LIMITATIONS }\end{array}$} & $\begin{array}{l}\text { Research exemption } \\
\text { Research-on- } \\
\text { exemption }\end{array}$ & $\begin{array}{l}\text { Industry neutral } \\
\text { Effect on innovation DNA, research tools } \\
\text { Micro policy lever } \\
\text { Statutory (EU + national) }\end{array}$ \\
\hline & $\begin{array}{l}\text { Research-on-plus-with- } \\
\text { exemption }\end{array}$ & $\begin{array}{l}\text { Industry specific } \\
\text { Created to have an effect on follow-on innovation } \\
\text { in biotechnology (DNA, research tools) } \\
\text { Macro policy lever } \\
\text { Statutory (national) }\end{array}$ \\
\hline & $\begin{array}{l}\text { Compulsory licensing } \\
\text { for public health/public } \\
\text { interest }\end{array}$ & $\begin{array}{l}\text { Industry specific } \\
\text { Effect on innovation in pharmacy (medicines) and } \\
\text { biotechnology (diagnostic methods) } \\
\text { Macro policy lever } \\
\text { Statutory (national) }\end{array}$ \\
\hline & Patent term & $\begin{array}{l}\text { Industry specific } \\
\text { Effect on innovation in pharmaceutical sector } \\
\text { Macro policy lever } \\
\text { Statutory (national) }\end{array}$ \\
\hline
\end{tabular}

Table 2. Detailed Overview of European Policy Levers in Biotechnology

The list of policy levers presented here is by no means exhaustive. Most probably additional rules, standards or doctrines can be uncovered. Rather, the policy levers discussed here can be considered as the most visible exponents, as yet, of the attempt of the European patent actors (legislators and courts) to tailor patent law to the needs of the biotechnology sector. The multitude of levers shows that the current European patent system holds substantial potential for technology-specific application of its patent law. Even though the EPC may have been conceived at its inception as a nominally neutral patent statute, our study clearly reveals that substantial discretion to differ the patent system by industry, and in particular to tailor it to the specificities of the biotechnology sector, is built into the system over the years. Although the EPC was introduced as a unitary ${ }^{264}$ regulatory tool, intended to operate the same way across

${ }^{264}$ The term 'unitary' comes from Burk and Lemley (The Patent Crisis, 2009, 65) as does the term 'uniform' (The Patent Crisis, 2009, 95). 
technologies, EPO case law has shown increased interest and ability in tailoring patent law to the needs of distinct technology sectors, and in particular the biotechnology sector.

\subsubsection{Macro versus micro policy levers}

Our study shows that in Europe substantially more micro policy levers have been set to work in the biotechnology sector than macro policy levers (See Table 3. Comparison of the Various European Policy Levers in Biotechnology. Also see Table 4. Summary of the Various European Policy Levers in Biotechnology).

\begin{tabular}{|c|c|c|c|c|c|}
\hline & & \multicolumn{2}{|c|}{$\begin{array}{l}\text { Macro policy lever } \\
\text { (industry specific) }\end{array}$} & \multicolumn{2}{|c|}{$\begin{array}{l}\text { Micro policy lever } \\
\text { (industry neutral) }\end{array}$} \\
\hline & & $\begin{array}{l}\text { Pre-grant (acquisition, } \\
\text { scope) }\end{array}$ & \begin{tabular}{|l|} 
Post-grant \\
(rights, limitations)
\end{tabular} & $\begin{array}{l}\text { Pre-grant (acquisition, } \\
\text { scope) }\end{array}$ & $\begin{array}{l}\text { Post-grant } \\
\text { (rights, limitations) }\end{array}$ \\
\hline \multirow[t]{4}{*}{ Statutory } & $E P C$ & \begin{tabular}{|l|} 
- Medical methods \\
- Medical use (first)
\end{tabular} & & & \\
\hline & \begin{tabular}{|l} 
EU (Biotech \\
Directive)
\end{tabular} & $\begin{array}{l}- \text { Industrial } \\
\text { applicability (DNA) }\end{array}$ & & & \\
\hline & $E U \rightarrow$ national & & & & $\begin{array}{l}\text { Research } \\
\text { exemption (on) }\end{array}$ \\
\hline & national & $\begin{array}{l}\text { - Limited scope } \\
\text { product claims } \\
\text { (purpose bound) }\end{array}$ & \begin{tabular}{|l} 
- Research \\
exemption (on- \\
plus-with) \\
- Compulsory license \\
public health \\
- Patent term
\end{tabular} & & \\
\hline Jurisprudential & $E P O$ & & & $\begin{array}{l}\text { - Selection invention } \\
\text { - Testing exemption } \\
\text { - Expectation of } \\
\text { success } \\
\text { - Commercial } \\
\text { success } \\
\text { - Industrial } \\
\text { applicability } \\
\text { (general) } \\
\text { - PSITA } \\
\text { - Clarity of claims } \\
\text { - Breadth of claims }\end{array}$ & \\
\hline \multirow[t]{2}{*}{$\begin{array}{l}\text { Jurisprudential } \rightarrow \\
\text { Statutory }\end{array}$} & \begin{tabular}{|l}
$E P O \rightarrow E U$ \\
(Biotech \\
Directive)
\end{tabular} & & & $\begin{array}{l}\text { - Invention (technical } \\
\text { character) }\end{array}$ & \\
\hline & $\begin{array}{l}E P O \rightarrow E P C \\
\end{array}$ & $\begin{array}{l}\text { - Medical use } \\
\text { (second) }\end{array}$ & & - Enabling disclosure & \\
\hline $\begin{array}{l}\text { Statutory } \rightarrow \\
\text { Jurisprudential } \rightarrow \\
\text { Statutory }\end{array}$ & \begin{tabular}{|l|}
$E P C \rightarrow E P O \rightarrow E U$ \\
\end{tabular} & & & - Morality & \\
\hline
\end{tabular}

(") The polioy levers whioh were split up (first/second medioal use; industrial applicability DNA/general; researoh on/on-with) have been printed in grey-

The prevalence of micro policy levers rather comes as a surprise. We expected that a relation would show up between the nature of policy measure (macro/micro) and the type of policy actor (legislator/court), and awaited a positive correlation between macro policy levers and statutory measures. Indeed, given the civil law background in which European (patent) law develops, a prevalence of well articulated macro rules openly set forth by the legislature was anticipated. However, a clear prevalence of jurisprudential micro policy levers emerged. 


\begin{tabular}{|c|c|c|c|c|c|}
\hline & \multicolumn{2}{|c|}{ Macro policy lever } & \multicolumn{2}{|c|}{ Micro policy lever } & \\
\hline & $\begin{array}{l}\text { Pre-grant } \\
\text { (acquisition, } \\
\text { scope) }\end{array}$ & $\begin{array}{l}\text { Post-grant } \\
\text { (rights, } \\
\text { limitations) }\end{array}$ & $\begin{array}{l}\text { Pre-grant } \\
\text { (acquisition, } \\
\text { scope) }\end{array}$ & $\begin{array}{l}\text { Post-grant } \\
\text { (rights, } \\
\text { limitations) }\end{array}$ & \\
\hline $\begin{array}{l}\text { Statutory } \\
\text { (EPC + EU + national) }\end{array}$ & 4 & 3 & - & 1 & 8 \\
\hline $\begin{array}{l}\text { Jurisprudential } \\
\text { (EPO) }\end{array}$ & & & 8 & & 8 \\
\hline $\begin{array}{l}\text { Jurisprudential } \rightarrow \\
\text { Statutory }\end{array}$ & 1 & & 2 & & 3 \\
\hline $\begin{array}{l}\text { Statutory } \rightarrow \\
\text { Jurisprudential } \rightarrow \\
\text { Statutory }\end{array}$ & & & 1 & & 1 \\
\hline Subtotal & 5 & 3 & 11 & 1 & 20 \\
\hline Total & \multicolumn{2}{|c|}{8} & \multicolumn{2}{|c|}{12} & 20 \\
\hline
\end{tabular}

Table 4. Summary of the Various European Policy Levers in Biotechnology *

(*) For sake of comparison, the policy levers split up in Tables 2 and 3 (first/second medical use; industrial applicability DNA/general; research on/on-with) have been counted as separate policy levers here. This leads to an increase of the policy levers with 3 . The net amount of policy levers uncovered would be 17 in stead of 20 .

Several of the micro policy levers have a direct impact on the biotechnology sector. Clear examples are the technical character approach, ${ }^{265}$ the morality doctrine, ${ }^{266}$ the selection invention rule ${ }^{267}$ and the testing exemption rule. ${ }^{268}$ However, many micro policy levers rather produce an indirect effect on the biotechnology industry. Some policy levers rather affect the biotechnology sector indirectly because it is a young, advanced and complex industry branch. An illustrative example is the use of the expectation of success doctrine. ${ }^{269}$ This nominally neutral doctrine does not produce an effect in well defined technology or industry sectors. Rather, the doctrine has an effect in 'young' industries, such as biotechnology, where the level of uncertainty is high, compared to 'established' industries where the level of uncertainty is low(er). A similar example is the skilled person doctrine. ${ }^{270}$ The rule is not being perceived differently in different industry sectors. Rather, the level of the skilled person differs between 'old' and 'new' fields of research. In 'old', conventional technical areas the standard of the PSITA seems to be low(er) than the level of the PSITA in 'new' technological fields. And, rather, the level of PSITA differs between 'low' and 'advanced' technologies. In 'low' key technologies, the level of the PSITA seems to be lower, as it can be a single skilled person. In advanced and more complex fields of research, the level is higher, as the PSITA can be held to be a team of skilled persons. Since the biotechnological field is both 'new' and pretty 'advanced', the level of the PSITA can differ from other sectors, and the PSITA can, indirectly, be seen as a judicial micro policy lever in biotechnology. Yet another example is the breadth of claim doctrine and the related pioneering patent rule. This doctrine does not produce a specific effect in a particular sector. Rather, the broad claim doctrine is more likely to be accepted in 'new' technology fields, such as the early days of biotechnology, than in 'known' technology fields, such as the later stages within those areas of biotechnology which have already been widely explored. ${ }^{271}$

\footnotetext{
${ }^{265}$ See section 2.1.1. of the present paper.

${ }^{266}$ See section 2.1.2. of the present paper.

${ }^{267}$ See section 2.1.5. of the present paper.

${ }^{268}$ See section 2.1.6. of the present paper.

${ }^{269}$ See section 2.1.7 of the present paper.

${ }^{270}$ See section 2.1 .10 of the present paper

${ }^{271}$ See section 2.2.3 of the present paper.
} 
Quite exceptionally, some policy levers are both a macro and micro policy lever. The key example here is the industrial applicability rule, which acts as a macro policy lever in biotechnology, since it clearly sets a higher standard for human genes by demanding a 'function'. The same rule acts as a micro policy lever in the pharmaceutical sector, since it unintentionally produces a greater effect in industry sectors characterized by downstream innovation. ${ }^{272}$

\subsubsection{Statutory versus jurisprudential policy levers}

In Europe, about the same amount of statutory and jurisprudential policy levers has been put into operation to tailor the biotechnology sector according to our study. The statutory policy levers come into being by an explicit action from the legislature. At various occasions, the EU legislator has expressly introduced exceptions to patentable subject matter and has modulated patentability requirements, resulting in a different gate of entry for biotechnological innovations. The EU legislator believed that achieving optimal innovation in biotechnology required explicit intervention through statutory initiatives. This should not come as a surprise, in view of the fact that Europe is characterized by a civil law tradition, where formal interventions of government are much more common practice than in common law jurisdictions.

The jurisprudential policy levers were either explicitly, either implicitly implemented by the EPO Boards of Appeal. ${ }^{273}$ Illustrative examples of micro policy levers, explicitly deployed in European case law in biotechnology are the expectation of success rule, ${ }^{274}$ the PSITA standard ${ }^{275}$, the enabling disclosure doctrine ${ }^{276}$, and, to a lesser extent, the selection invention doctrine. ${ }^{277}$ Key examples of policy levers implicitly put to work in biotechnology are the clarity of claims and the breadth of claims doctrine. It remains to be seen, to what extent the explicit policy levers encountered here, give evidence of a deliberate and conscious attempt within the EPO to apply the same rules differently in different sectors. Our research indicates that the expectation of success rule and the PSITA standard ${ }^{278}$ did not vary in biotechnology compared to other industries, but rather differed according to features such as young/experienced industry, old/new fields of research and low/advanced technologies. Furthermore, differentiation is not been signaled as a major issue within the EPO, witness the clear and strong attention for quality, not for (the maintenance of) diversity, in some recent high level documents from the EPO. ${ }^{279}$

\footnotetext{
${ }^{272}$ See section 2.1 .9 of the present paper.

273 To decide whether policy levers were put to work explicitly or implicitly, we examined which of the jurisprudential EPO levers we uncovered, were mentioned under a separate heading in EPO, Case Law of the Boards of Appeal, 2006 and in the EPO Guidelines - Part C - 2010. We admit this is a pretty 'rough' method to discern explicit and implicit use of policy levers. More refined analytical tools need to be thought of.

${ }^{274}$ EPO, Case Law of the Boards of Appeal, 2006, p. 132 (see Section I. Patentability - D. Inventive Step - 6. Expectation of success, especially in the field of genetic engineering and biotechnology).

${ }^{275}$ EPO, Case Law of the Boards of Appeal, 2006, p. 136 (see Section I. Patentability - D. Inventive Step - 7. Skilled person - 7.1.3. Definition of the skilled person in the art in the field of biotechnology).

${ }^{276}$ EPO, Case Law of the Boards of Appeal, 2006 p. 178 (see Section II. Conditions to be met by an application - A. Sufficiency of disclosure -5 . The requirement of sufficiency of disclosure in the biotechnology field).

${ }^{277}$ EPO, Case Law of the Boards of Appeal, 2006, p. 87 (see Section I. Patentability - C. Novelty - 4. Chemical inventions and selection inventions).

${ }^{278}$ See up, section 3.1.2.

${ }^{279} C f$. Alison Brimelow (EPO President), 'Securing the stability of the patent system', in EUROPEAN PATENT OFFICE, Annual Report 2008, Munich, EPO, 2009, p. 5-7: "It is now also clear that the consequences of the unforeseen success of patents are not all positive, as is evident from frequently critical public reactions to issues such as the growing mounds of unprocessed applications. Accordingly, the European Patent Office (EPO) last
} 
The use of specific policy levers in EPO case law has far reaching effects. First, because the deployment of certain levers by the EPO Boards has an influence on the legislator. Quite often, the jurisprudential levers have given the impetus for the introduction of statutory levers. Looking at certain policy levers in the field of biotechnology in Europe, teaches that some contemporary statutory policy levers, were initially created by the EPO Boards. An illustrative example is the technical character rule: originated as a judicial policy lever, the technical character rule was later formally embedded in patent legislation, namely in the EU Biotechnology Directive, which makes it a statutory policy lever. ${ }^{280}$ Another key example is the morality clause: initially embedded in the EPC as a rather pale provision (article 53 (b) EPC), the morality clause was activated at the advent of biotechnology by the EPO Boards of Appeal, and was later on captured by the legislator, who implemented the clause it in a formal patent statute, namely the EU Biotechnology Directive. ${ }^{281} 282$ Yet another example, is the second medical use rule: originally shaped by EPO case law, the rule was later formally enacted in the EPC. ${ }^{283}$

The application of certain policy levers in EPO case is furthermore highly influential, as certain EPO judicial levers may have effects on national courts. Although EPO verdicts do not have any precedent value on the courts of the EPC contracting states, which are totally autonomous in their rulings, EPO case law has a great influence on national judges and ultimately carries great weight in defining the patent practice in Europe. Illustrative in this regard is the statement of UK justice Neuberger in the Kirin-Amgen case: "I am reluctant not to follow the approach of the Board, particularly in light of the sheer number of consistent decisions on this point. However, I am not bound by decisions of the Board...". ${ }^{284}$ Given the few patent infringement and nullity cases in the various EPC member states, the decisions of the EPO Boards are vital to the efficient operation of the patent system in Europe, and are

year intensified its efforts to make the patent system more effective both in Europe and internationally, with special emphasis on enhancing procedural efficiency." [...] "In the EPO's view, the second key element in this stabilisation process is the ongoing review and improvement of the European procedure. The EPO is devoting particular attention to further enhancing patent quality, which is also dependent on the quality of the applications that are filed. Suitable rules governing divisional applications are being discussed, as are appropriate internal means of permanently raising the bar in terms of the quality of grant proceedings. Also see 'Quality over quantity: on course to raise the bar', EPO, Annual Report 2008, Munich, EPO, 2009, p. 8: “A final issue in the same context concerns the influence that can be exerted through the EPO's fee structure and hence the best approach to financing the European patent system in order to guarantee its stability in the long term as well". A portfolio of measures set to launch in the spring of 2010 will raise the bar on the quality of patents while simultaneously improving the efficiency of the granting process. These steps will better protect inventors who turn to the European Patent Office and, at the same time, see the EPO grant patents only for innovations having sufficient inventive merit and meeting the needs of society. This programme of measures has been designed with three aims in mind: to secure a clear scope for the search at the beginning of the procedure and thereby build on solid foundations; to save time in the application process by reducing the procedural steps through which inventors and the EPO must pass; and, ultimately, to increase the chances of worthy applicants being granted robust patents". Also see an EPO comment entitled "Raising the bar"on the new EPO measures entering into force on April 1 2010: "As reported in Patent Information News 2/2009, the "Raising the bar" initiative at the EPO is not about raising the level of inventive step. Rather, it aims to communicate current best practice with respect to the assessment of inventive step at the EPO and to ensure a consistent and clear standard for the assessment of inventive step across all technical fields" (EPO Patent Information News, 2010, Issue 1, March 2010, p. 1) (My Italics).

${ }^{280}$ See section 2.1.1. of the present paper.

${ }^{281}$ See section 2.1.2. of the present paper.

${ }^{282}$ As we have explained earlier, policy levers introduced by the EU Biotechnology Directive then trickled down to the national statutory level, as well as the EPC level, through the Implementing Regulations.

${ }^{283}$ See section 2.1.4. of the present paper.

${ }^{284}$ Chancery Division (Patents Court), 11 April 2001, Kirin-Amgen Inc. vs Roche Diagnostics Gmbh. 
particularly useful to the court systems of the smaller countries whose low number of decided cases provides little help to would-be plaintiffs or defendants. ${ }^{285}$

Not only rulings from the EPO Technical Boards of Appeal or from the Enlarged Board of Appeal may produce far reaching effects, also decisions from the EPO Opposition Division can create significant industry specific flexibility. Cases in point are the foundational interpretations of the morality clause by the Opposition Division to allow patents in the field of human genes (Howard Florey) ${ }^{286}$ and transgenic plants (Lubrizol). ${ }^{287}$

The reverse influence of national jurisprudential levers on EPO case law is far less prominent. Even when a court of an EPC contracting state would put into operation a policy lever in the field of biotechnology, it is quite unlikely that this lever would be picked up at the European level and be formally embedded in the EPC or be translated into an EU measure. National courts have no say over the EPO, let alone the EU, so policy levers applied nationally, do not feed back into the European system automatically. National (civil) courts hardly play a role here in triggering modifications in the EPC. Much more than creators of policy levers, national courts in Europe, are followers - and to a certain extent also watchdogs - of the policy levers established by the EPO. ${ }^{288}$

Jurisprudential differentiation has various advantages, as Burk and Lemley have repeatedly pointed out. ${ }^{289}$ Jurisprudential diversification, however, can also have some downsides. Statutory levers are explicitly articulated and thus create transparency and (a great level of) legal certainty. Jurisprudential levers, however, may be applied implicitly, and, furthermore, may change over time, which may lead to legal uncertainty.

\subsubsection{Pre-grant versus post-grant policy levers}

Our study shows that in Europe much more pre-grant policy levers have been put to work, compared to post-grant policy levers (see Table 4. Summary of the Various European Policy Levers in Biotechnology). Some sixteen pre-grant policy levers have been encountered, versus four post-grant policy levers. This result may be due to the fact that our research did not include national case law, which might have shed some more light on the application of post-grant policy levers.

Quite remarkably, the majority of pre-grant levers are jurisprudential in nature or have started off as case law levers and were later embedded in statutes (12/16, see Table 4. Summary of the Various European Policy Levers in Biotechnology). All post-grant levers (4/20), are national statutory levers.

\subsubsection{European versus national policy levers}

The results on pre-grant versus post-grant levers, should not come as a surprise in light of the current institutional patent architecture. Deciding on the coming into existence of European patents - and thus on putting into operation pre-grant policy levers relating to patent

${ }^{285}$ BIRD, William, 'Using the EPO Opposition Procedure as a Strategy against Patents on Diagnostic Methods', in VAN OVERWALle, G. (ed.), Gene Patents and Public Health, Brussel, Bruylant, 2007, 73-84. previous footnote

${ }^{286}$ See section 2.1.2, and more in particular the decision of the Opposition Division in the Howard Florey case.

${ }^{287}$ See section 2.1.2, and more in particular the decision of the Opposition Division in the Lubrizol case.

${ }^{288}$ Cf. Burk \& Lemley? Check

${ }^{289}$ Burk and Lemley have a clear preference for case-by-case judicial tailoring by the courts and clearly indicate why. See check reference. 
acquisition and patent scope - is the exclusive competence of the EPO, encompassing legislative (EPC) and judicial branches (EPO Boards). In contrast, deciding on the exercise of patents - and thus on the putting into effect post-grant levers relating to patent rights and limitations - is the exclusive competence of EPO member states. ${ }^{290}$

Against this background of division of competences, it was to be expected that policy levers relating to patent acquisition and patent scope would mainly originate within the EPO, whereas policy levers on patent rights and limitations would come about at the national level. More insightful information is to be expected when research will be expanded to national jurisprudence.

\subsubsection{Private interest versus public interest levers}

Not all policy levers uncovered in the present study, may come to the advantage of the biotechnology industry. Closer analysis of the various policy levers, reveals that rather than expanding the patent system to accommodate biotechnology inventions and to stimulate innovation in the biotechnology sector, some policy levers narrow down the patent potential for biotechnological inventions in Europe. "Tailoring" the patent system to biotech inventions does not always result in broadening, but can also end up in limiting the patent incentive.

Policy levers to expand the current the patent realm towards biotechnological inventions, definitely include the technical character rule as applied to DNA (turning DNA from discoveries into inventions), the first and second medical use doctrine and the selection invention rule.

Policy levers intended to narrow down the gate of patent entry for biotechnological inventions can be classified in three distinct categories. A first series of limiting policy levers is put into operation to foreclose appropriation of technical knowledge, to increase the public domain and to facilitate research and development and follow-on innovation in biotechnology. Clear examples are the purpose bound doctrine (limited scope of product claims) and the research on-plus-with exception rule. A second series of minimizing policy levers is put to work to safeguard public health. An illustrative example is the medical method doctrine, which was established in a concern to ensure that those who carry out such methods as part of the medical treatment of humans or the veterinary treatment of animals are not inhibited by patents. ${ }^{291}$ Another example is the compulsory license for public health, which was introduced to seize abusive patent holders in the area of biotechnology and pharma, in an attempt to ensure fair and reasonable licensing negotiations, hence, reasonable access to healthcare. A third series of diminishing levers feeds into the ethical sensitivity surrounding bio-patents. The most prominent example in this regard is the use of the morality clause.

\subsection{Comparing European and US policy levers}

Burk and Lemley describe a dozen policy levers courts already use to differentiate patent law in different industries. ${ }^{292}$ Some of these policy levers are also put into practice in Europe to accommodate biotechnological inventions. This is the case for the abstract idea-technical character rule, ${ }^{293}$ the commercial success doctrine, ${ }^{294}$ the industrial applicability/utility

\footnotetext{
${ }^{290}$ See section 2.2.

${ }^{291}$ See section 2.1 .3 of the present paper.

${ }^{292}$ See Burk \& Lemley, The patent crisis, 2009, p. $109 \mathrm{ff}$.

${ }^{293}$ See Burk \& Lemley, The patent crisis, 2009, 122-124.

${ }^{294}$ See Burk \& Lemley, The patent crisis, 2009117-118.
} 
standard, ${ }^{295}$ the PSITA/PHOSITA approach, ${ }^{296}$ the enabling disclosure requirement, ${ }^{297}$ the pioneering patent rule ${ }^{298}$ and the research exemption/experimental use doctrine. ${ }^{299}$ Other policy levers have not clearly shown up when screening European patent law for biotechnology shaped rules or doctrines. This is the case for the reasonable interchangeability doctrine, ${ }^{300}$ the element-by-element analysis, ${ }^{301}$ the reverse doctrine of equivalents, ${ }^{302}$ and the reasonable royalty rule. ${ }^{303}$

Rules that were put into operation as macro policy levers in the US, were often - but not always - also employed as macro policy lever in Europe. An illustrative example is the enabling disclosure rule, which has been applied differently to biotechnology and software in both constituencies. Or the industrial applicability/utility rule which is applied more stringently in biotechnology, especially with regard to DNA inventions, than in other sectors. On the other hand, rules or doctrines that were deployed as micro policy levers in the US, were often put to work in the same fashion in Europe. As way of example, we refer to the secondary considerations of non-obviousness, more in particular the commercial success doctrine, which is being applied nominally across all technology sectors, but which primarily benefits industries that deal with inventions that translate directly into commercial products. ${ }^{304}$

\section{Critical assessment. “The patent crisis” revisited}

Now we have arrived at the end, we would like to turn to the beginning of the book which prompted our study. And we would like to examine the normative underpinnings of the Burk and Lemley approach. Our study joined the points of departure set forth by Burk and Lemley, and provided an insightful descriptive tour d' horizon of current policy levers put into operation in European patent law in the area of biotechnology. We would now like to take a closer look at these starting points, especially in the light of our findings.

Based on the overwhelming economic evidence that innovation and patent patterns are different in different industries, Burk and Lemley conclude that a purely unitary system no longer fits the diverse needs of technology innovation. They claim that (1) tailoring the unitary patent rules on a case-by-case basis to the needs of the different industries (2) by the courts, is the best solution to resolve current patent crisis. This twofold claim raises some fundamental questions.

\subsection{Role and motivation for tailoring}

Burk and Lemley claim that the best response to industry specific innovation and patent patterns is tailoring of the unitary patent rules: "The doctrines we have discussed ... all

\footnotetext{
${ }^{295}$ See Burk \& Lemley, The patent crisis, 2009, 110-112.

${ }^{296}$ See Burk \& Lemley, The patent crisis, 2009, 114-117.

${ }^{297}$ See Burk \& Lemley, The patent crisis, 2009, 118-122.

${ }^{298}$ See Burk \& Lemley, The patent crisis, 2009, 127-128.

${ }^{299}$ See Burk \& Lemley, The patent crisis, 2009, 112-114.

${ }^{300}$ See Burk \& Lemley, The patent crisis, 2009, 124-125.

${ }^{301}$ See Burk \& Lemley, The patent crisis, 2009, 125-126.

${ }^{302}$ See Burk \& Lemley, The patent crisis, 2009, 128.

${ }^{303}$ See Burk \& Lemley, The patent crisis, 2009, 128-130.

${ }^{304}$ Burk \& Lemley, The Patent Crisis, 2009, 110.
} 
implicate the technology-specific potential of patent law, and they are all capable of being used to bring patent law in line with optimal patent policy". 305

But is the tailoring of the patent system to diverse needs of industries indeed the best option? Is tailoring per se better? Is a non-unitary patent system per se better? And why? Why is tailoring the unitary patent rules on a case by case basis the best solution? On what grounds? Why should patent law be applied with sensitivity to the characteristics of different industries? In their book, Burk and Lemley do not provide well established normative criteria in responding this question. The authors do not extensively argue, nor (explicitly) articulate in depth which criteria have been applied to reach this viewpoint. Only some vague indications of why one solution is more "attractive" ${ }^{306}$ than another are put forward, such as flexibility ${ }^{307}$ and favoritism. ${ }^{308}$ Previous work, reveals somewhat better the (implicit) ideology underlying their approach. In their path-breaking article from 2003, 'Policy levers in patent law', ${ }^{309}$ Burk and Lemley explicitly join the consensus position that the major objective of the patent system is to promote innovation by granting exclusive rights. They link up with the standard understanding that patent law is a utilitarian mechanism to encourage investors to invest. According to Burk and Lemley, the best way to achieve this one goal, is not to apply the one tool similarly across industries, but to apply the patent tool differently in different industries. ${ }^{310}$ Modulating patent law will best serve the goal patent law is set to achieve. Adjusting patent law to different sectors will best serve the economic effect on innovation.

But, will tailoring patent law to the needs of industry always result in a fair outcome? Will modulating patent law provide the fairness of a just reward? Might tailoring not result in either over-rewarding or under-rewarding certain innovators or industries? And what about legal certainty in a regime which is being applied differently per industry sector, and where changing and wobbling norms are set forth? Not to speak of transparency. What about a system where differing norms are being applied implicitly and unconsciously? And not well articulated standards float around in administrative patent agencies?

The point is taken that tailoring patent law may well provide more adequate impulses to innovation. But, effect on innovation may not be the only criterion to measure the value of tailoring. Other elements - such as fairness of a just reward, legal certainty and transparency may spur a more nuanced decision on what is the best way to accommodate differing patterns of innovation.

Articulating why tailoring is the best solution, will help in deciding whether or not more or less tailoring is desirable. An important question for Europe is whether we should retain the current system, and acknowledge and embrace the sectorial differences established by the legislature and the patent offices, or whether we should call for a stand still. In Europe

\footnotetext{
${ }^{305}$ Burk \& Lemley, The Patent Crisis, 2009, 130 (my italics).

${ }^{306}$ Burk \& Lemley, The Patent Crisis, 2009, 6.

307 "A patent system that lacks the flexibility to deal with radical differences between industries will break rather than bend" (Burk \& Lemley, The Patent Crisis, 2009, 6).

308 "And a patent system whose flexibility depends on particular industries lobbying Congress for specialized rules unlikely to produce desirable rules. .. the lessons of recent efforts at patent reform are not encouraging for those who would rely on Congress" (Burk \& Lemley, The Patent Crisis, 2009, 6).

${ }^{309}$ Dan L. Burk and Mark A. Lemley, Policy levers in patent law, Research paper 2003(available through SSRN).

${ }^{310}$ Given the idiosyncratic profile of technical and economic determinants for research, development and return on investment each distinct technology displays, there is no a priori reason to believe that a single type of legal incentive will work best for ever industry. "Indeed, there is every reason to believe that achieving optimal innovation in different industries will require greater or lesser measures of legal incentives", Burk \& Lemely, Policy levers in patent law, 2003, p. 23 (My Italics).
} 
significant tailoring with regard to eligible subject matter exists. But, do we need more? And what for? There is also significant differentiation with regard to patentability requirements. But, do we want more? The same question applies to modulation with regard to scope of protection and exercise of rights.

\subsection{Role of the courts}

Burk and Lemley further claim, that courts are best placed to modulate the patent system and are "best positioned" 311 to tailor patent law to the varying needs of industry. They suggest that, as a general principle, a flexible common-law approach of ongoing judicial oversight will best accommodate new and different technologies within the general framework of a patent statute". ${ }^{312}$

Here, Burk and Lemley do explain why legislatures and administrative agencies are ill-placed to address statutory upkeep. The authors are by far not convinced that it is a good idea to leave the tailoring to the legislator: practical unfeasibility ${ }^{313}$, legal uncertainty ${ }^{314}$, demarcation problems ${ }^{315}$ and lack of general character ${ }^{316}$ may be the downsides of legislative interference. A number of elements caution against the tailoring of the patent system to the needs of particular industries by administrative agencies too: lack of accountability (of the staff of the administrative agency) ${ }^{317}$ and lack of neutrality - consumer prejudice. ${ }^{318}$

But, the positive choice for the courts to carry out an industry-specific judicial policy is based on a (rather poor) authoritative and pragmatic argument, rather than on a normative one, it seems. It is argued that courts can and should apply the general rules of patent law with sensitivity to the characteristics of different industries, because ... the Federal Circuit already does this, consciously or not. The patent statute and the common law of patents are "chockfull of examples of judicially created, industry specific rules". 319

Furthermore, can the second thesis of Burk and Lemley about the pivotal role of the courts hold out, in view of the European experience? The results of our study reveal that in European patent law a large part of the policy levers were put to work by the legislator, and another significant part was created by the courts and later codified in statutory law, in other words, legislative reform confirming judicial discretion. The European experience teaches that the

\footnotetext{
${ }^{311}$ Burk \& Lemley, The Patent Crisis, 2009, 5.

${ }^{312}$ Burk \& Lemley, The Patent Crisis, 2009, 104.

313 “... while economics can make useful policy suggestions as to how patents work in different industries, we are sceptical of the ability of a statute to translate those suggestions into detailed patent rules for each industry", Burk \& Lemley, The Patent Crisis, 2009, 97.

314 "Rewriting patent law for each industry would involve substantial uncertainty" since fewer interpretative cases would come up involving each statute", Burk \& Lemley, The Patent Crisis, 2009, 97.

315 "Industry specific legislation would also require a great deal of line drawing, as the boundaries between industries are vague and notoriously mutable. ... Drug delivery systems might be thought of as medical devices, pharmaceuticals or biotechnology.. presumably a different law would apply depending on how the invention was characterized", Burk \& Lemley, The Patent Crisis, 2009, 97.

316 "The history of industry-specific statutes suggests that many fail because they are drafted with then-current technology in mind and are not sufficiently general to accommodate the inevitable changes in technology", Burk \& Lemley, The Patent Crisis, 2009, 97.

${ }^{317}$ Burk \& Lemley, The Patent Crisis, 2009, 106.

318 "The PTO interacts regularly with those seeking patents, but very little with third parties affected by the patents they grant. It is little wonder, then, that the PTO in the 1990's stated its mission as "to help our customers get patents", Burk \& Lemley, The Patent Crisis, 2009, 106-107.

${ }^{319}$ Burk \& Lemley, The Patent Crisis, 2009, 109.
} 
patent system might also work with a legislature selectively applying industry-specific protection statutes.

Our study further shows that the most trendsetting case law under European patent law was set forth by the EPO Technical Boards of Appeal and the EPO Enlarged Board of Appeal, both organs within an administrative international body. Are the EPO Boards to be viewed as administrative organs and their verdicts as administrative decisions? Or, are the EPO Boards to be qualified as courts and their verdicts as true jurisprudential decisions? Recently, the EPO Boards of Appeal have been recognized as courts or tribunals of an international organization. ${ }^{320}$ Even if the question whether EPO Boards can be qualified as courts might be answered in the affirmative, do they fit the civil court concept Burk and Lemley have in mind? What is so specific, so unique about a civil court that they, and they only, can best perform the task of tailoring, rather than the judicial organs within the patent administration? The legal environment? Civil courts operate within a wide set of well recognized procedural and substantive laws, whereas the EPO is an international organization operating in an "incomplete legal environment". ${ }^{321}$ The training and background of the judges? Civil courts

\footnotetext{
${ }^{320}$ EPO Enlarged Board of Appeal (G 0002/06) (Wisconsin Alumni Research Foundation), 25 November 2008. The appellant argued that, since Rule 28 (c) EPC IRs(formerly Rule 23 (c) EPC IRs) repeated the wording of Article 6 (2) (c) of the EU Biotechnology Directive, the EPO Enlarged Board of Appeal was interpreting the law of the European Union (EU) and was required by Article 234 of the Consolidated Version of the Treaty establishing the European Community in force since 1 February 2003 under the Treaty of Nice signed 26 February 2001 (EC Treaty), as a court or tribunal of a member state against whose decision there is no judicial remedy, to ask for a ruling by the European Court of Justice (ECJ), in the present situation where the interpretation of Article 6 (2) (c) of the Directive is not free of doubt (i.e. not acte clair). The appellant claimed that the Enlarged Board of Appeal meets the ECJ criteria of being a court or tribunal, and ECJ case C-337/95 (Dior v. Evora) is a precedent for a court under an international treaty and having jurisdiction for more than a single EU member state asking for a ruling. The appellant further argued that the vast majority of EPC states are member states of the EU and the Enlarged Board of Appeal sits in such a state. Not asking the ECJ for a ruling, would bear the risk that national courts would subsequently apply (and be obliged to apply) an interpretation of Article 6 of the Directive which does not accord with that applied by the EPO (See under Point VI of the decision). The President of the EPO responded that "The Boards of Appeal of the EPO are not courts or tribunals of a member state of the EU, and there is no power under the EPC for a Board of Appeal to refer questions to the ECJ" (See under Point VII of the decision, Main points made on behalf of the President of the European Patent Office in writing and at the oral Proceedings). The EPO Enlarged Board of Appeal finally concluded that "Neither the EPC nor the Implementing Regulations thereto make any provision for a referral by any instance of the EPO of questions of law to the ECJ. The Boards of Appeal are a creation of the EPC, and their powers are limited to those given in the EPC. Prima facie the conclusion must be that the absence of any provision enabling such a referral makes such referral impossible" (Point 3 of the Reasons). "Nor does Article 234 of the EC Treaty giving the ECJ jurisdiction to give preliminary rulings concerning inter alia the validity and interpretation of acts of the institutions of the European Community, such as the Directive, appear to provide any basis for a Board of Appeal of the'EPO to request the'ECJ to give a ruling on any questions before such Board of Appeal. Article 234 of the EC Treaty requires the question to be raised in a case pending before a court or tribunal of an EU member state Whereas EPO Boards of Appeal have been recognized as being courts or tribunals, they are not courts or tribunals of an EU member state but of an international organization whose contracting states are not all members of the EU" (Points 4 of the Reasons). Last but not least, "The Administrative Council of the E?O as legislator responsible for the Implementing Regulations found it necessary to introduce what are now Rules 26 to 29 (formerly Rules $23 \mathrm{~b}$ to $23 \mathrm{e}$ EPC IRs) so that the provisions of the EPC correspond to those of the Directive. Thereby all Contracting States to the EPC, even those "not members of the EU, have indicated their will that these rules be used to interpret the EPC when considering whether or not a European patent should be granted. But this cannot be taken as conferring some new power or imposing some new obligation on the Boards of Appeal to ask for an interpretation by the ECJ of the EPC or its Implementing Regulations. Certainly the Contracting States to the EPC which are not member states of the EU cannot be presumed to have conferred jurisdiction on the ECJ" (Point 5 of the Reasons).

${ }_{321}$ Catarina Holz, Due process for European Patenting. A Comparative Jurisprudence Study, EPO, Munich, 2007, 3. Also see F. Morgenstern, Legal Problems of International Organisations, Cambridge, 1986, 3.
} 
are staffed with legally trained judges, whereas the EPO courts ${ }^{322}$ are mainly equipped with scientists. Their autonomy? Civil courts are staffed with independent judges, whereas the EPO Boards are crewed with bureaucrats, who, in spite of the fact that they are guaranteed independence and non-intervention from the executive powers as to their judicial functions (Article $23 \mathrm{EPC}$ ) may be found to fall short of the standards set up internationally for courts of law. ${ }^{323}$ Accountability? In US, direct recourse from the USPTO Board of Appeals is possible to civil courts, namely the Court of Appeals for the Federal Circuit (CAFC), whereas no direct recourse with a civil court, nor with the ECJ, ${ }^{324}$ is possible against the decisions from the EPO Boards.

Spelling out what the necessary features of a court should be is needed. Defining which of the characteristics set forth here are relevant to be nominated as the best and most suitable actor, and examining to what extent the EPO Boards fit into this best actor definition, is most desirable. This will help in deciding who is best positioned to tailor industry's diverse needs in the future in Europe, the legislator, the EPO Boards or the national courts. A choice for the on or the other can only be made by weighing the various options against a set of well articulated and elaborated criteria.

\section{Final remarks}

\subsection{Future research}

Apart from more reflection on the basic normative assumptions underlying the Burk and Lemley viewpoint, more descriptive-analytical research needs to be done as well. The present study was our very first attempt to portray in a systematic manner the way in which policy levers have been put into operation in European patent law to accommodate bio-inventions. Although the results are very insightful already, the list of policy levers presented here is by far not complete. Most probably additional rules, standards or doctrines can be uncovered which have been created to accommodate biotechnological inventions. Further research is needed to bring additional policy levers, relevant in biotechnology, to the fore.

The present study examined three different bodies of patent legislation: the EPC and its Implementing Regulations, the EU Biotechnology Directive, and a selection of national patent acts, more in particular the patent acts of Belgium, the Netherlands and France. Future research should give more attention to the specific guidelines in the sector of biotechnology introduced by patent offices. More in particular, the EPO Examination Guidelines, as well national guidelines, should be examined more systematically to see whether additional levers can be discerned.

For the present study, only one of the three levels of patent case law was explored in depth: the EPO case law of the Technical Boards of Appeal, including decisions from the Technical

\footnotetext{
${ }^{322}$ We will not go into the issue again here, whether the EPO Boards of Appeal can be considered to be 'courts'. See up under section 1.2.1.

${ }^{323}$ See Council of Europe Recommendation No R (94) on the independence, efficiency and role of the judges, which lays down a minimum standards for national courts of law.

${ }^{324}$ No appeal lies open from the EPO to the European Court of Justice, contrary to the current regime for Community Plant Variety Rights and Community Trademarks. Also see up under section 1.2.1
} 
Boards of Appeal and the Enlarged Boards of Appeal. To obtain a more complete picture of the current use of policy levers in case law, further research needs to be carried out to explore even more EPO case law. In addition, the current overview needs to be complemented with jurisprudential decisions from national courts. Even though the analysis of EPO case law may be quite indicative for the current use of policy levers in biotechnology, further research is needed to provide a more complete sketch. Analyzing biotechnology related case law of the courts in the 36 EPC contracting states seems like a daunting task, but one that might be extremely informative on the workings of European patent law in practice. ${ }^{325}$ Last but not least, awaited case law of the ECJ needs to be followed up. ${ }^{326}$

The present study focused on policy levers in the biotechnology sector. Studying policy levers in another industry sector, for example, software would contribute to the analysis, as it would provide a kind of benchmark, and deepen our understanding of the levers in biotechnology.

Our study analyzed policy levers independently from one another. However, the optimal setting for any given policy lever may depend in part on how other levers are deployed. ${ }^{327}$ There is an extensive economics literature on the interaction between intellectual property policy levers. Further research is also needed to examine the interaction between different policy levers in biotechnology.

And this brings us to our last point. The results of the present study call for further study in the light of economic theories and findings on the various modes of innovation, and on the interrelationship between innovation theories and patent theories. There is a vast body of literature on this issue which has not been taken into account yet in the present study. ${ }^{328}$ It will also be most interesting to look into empirical economic evidence on the effects of the differing use of policy levers across industries. ${ }^{329}$

\footnotetext{
${ }^{325}$ Such a quest may well be initiated by analyzing the cases discussed in European Patent Office, European National Patent Decisions Report, 2004. Even though the selection of cases is very limited, they may represent a good starting point, having to be supplemented with a state of the art search for national case law.

${ }^{326}$ Two cases are currently pending before the ECJ. First, a request from the Dutch court of 's Gravenhage of 24 September 2008 concerning the scope of patent claims for transgenic plants (Articles 8 and 9 of the EU Biotechnology Directive) (See Bijblad Industriële Eigendom, 2009, 403). Second, a request from the German Bundesgerichtshof (the Federal Court of Justice) of 17 December 2009 concerning the ability of an inventor to patent methods and products involving the use of human embryonic stem cells (Article 6 of the EU Biotechnology Directive) (See Decision Xa ZR 58/07, available at www.bundesgerichtshof.de).

${ }^{327}$ What has been examined most so far, is the interaction of length and breadth. See, e.g., Richard Gilbert and Carl Shapiro, Optimal Patent Length and Breadth, 21 RAND J. Econ. 106 (1990); Paul Klemperer, How Broad Should the Scope of Patent Protection Be?, 21 RAND J. Econ. 113 (1990); Nancy T. Gallini, Patent Length and Breadth with Costly Imitation, 24 RAND J. Econ. 52 (1992). See Suzanne Scotchmer, The Law and Economics of Reverse Engineering, 111 Yale L.J., 1575, 1581 (2002), for more references (footnote 345).

${ }^{328}$ See Burk \& Lemley, The Patent Crisis, 2009, 79-92 and the references cited there. Also see Dan L. Burk and Mark A. Lemley, Policy levers in patent law, Research paper 2003, and the references cited there; Dan L. Burk and Mark A. Lemley, Is Patent Law Technology-Specific?, 17 Berkeley Technology Law Journal, 2002, 11551206 and the references cited there. Also see Dominique Guellec and Bruno Van Pottelsberghe de la Potterie, The Economics of the European Patent System, Oxford, Oxford University Press, 2007, 250 p. and the many valuable references cited there.

${ }^{329}$ An example of such research, providing more than just some more anecdotal evidence, is to be found in Hazel V.J. Moir, How high is the inventive step? Some empirical evidence, Paper presented at the $4^{\text {th }}$ Annual Conference of the EPIP Association, Bologna, Italy, September 24-25 2009. Also see, Dahlin, K.B. and D.M. Behrens, When is Invention Really Radical? Defining and Measuring Technological Radicalness, 34(5) Research Policy, 2005, 717-737.
} 


\subsection{Concluding thoughts}

A big value of the book The Patent Crisis and How the Courts can Solve It of Burk and Lemley is that it demystifies the image of a unitary patent system. The authors collected wide evidence that the current, nominally technology-neutral patent system, in fact has different effects in different industries. Further, they demonstrate that the courts can play a pivotal role in further tailoring the patent system to the differences in varying technological sectors. The courts do apply the nominally unitary patent system with sensitivity to the needs and features of different industries.

Turning the spotlights to Europe, our analysis shows that the alleged unitary European patent system, more in particular the EPC, is not always applied in the same way in different circumstances. Responsible for tailoring the patent system to the diversities in differing technological sectors, are not the civil courts, but the EPO, by way of administrative case law. This internal case law, although having no precedence over national court decisions, has a wide effect, and at various occasions, has been integrated in European patent legislation.

European patent law holds substantial potential for technology-specific application. Even though the European Convention (EPC) may have been conceived at its inception as a nominally neutral patent statute, our study clearly reveals that substantial discretion to differ the patent system by industry, and in particular to tailor it to the specificities of the biotechnology sector, is built into the system over the years. Although the EPC was introduced as a unitary regulatory tool, intended to operate the same way across technologies, EPO case law has shown increased interest and ability in tailoring patent law to the needs of distinct technology sectors, and in particular the biotechnology sector.

Not all policy levers uncovered, come to the advantage of the biotechnology industry, though. Closer analysis of the various policy levers, reveals that rather than expanding the patent system to accommodate biotechnology inventions and stimulating innovation in the biotechnology sector, some policy levers narrow down the patent potential for biotechnological inventions in Europe, in an attempt to give echo to concerns of public health and ethical conscience. 